\title{
23. UPPER CRETACEOUS BENTHIC FORAMINIFERS AND PALEOENVIRONMENTS, SOUTHERN KERGUELEN PLATEAU, INDIAN OCEAN1
}

\author{
Patrick G. Quilty ${ }^{2}$
}

\begin{abstract}
Over 200 species of benthic foraminifers are recorded from three Ocean Drilling Program sites on the Southern Kerguelen Plateau drilled during Leg 120. They represent environments of deposition from neritic to bathyal during the Cenomanian to Maestrichtian. Many species are left in open nomenclature.

Analysis of planktonic percentage, dominance/diversity, and comparison of faunal composition and structure shows that at all sites there is strong evidence of deepening water with time.

The sediments at Sites 747 and 750 accumulated dominantly in open-ocean conditions of generally bathyal depths, increasing with time. The deepest faunas may represent lower bathyal depths. At Site $748 \mathrm{C}$, deposition began in marine conditions so shallow that there is no foraminiferal component at all and the environment may have been estuarine or salt marsh, in part with reducing conditions. After the Cenomanian/Turonian, conditions became more open marine, but waters were still very shallow so that planktonic percentage remains low.

Indexes other than foraminiferal suggest that the Kerguelen Plateau was vegetated through much of the Upper Cretaceous and that there may always have been islands or larger expanses of the plateau surface exposed.
\end{abstract}

\section{INTRODUCTION}

This paper records the distribution of benthic foraminifers from sites drilled by Ocean Drilling Program (ODP) Leg 120 (Schlich, Wise, et al., 1989) on the Southern Kerguelen Plateau in March-April 1988. It also discusses the benthic foraminifer faunal structure and employs that, together with other faunal information (planktonic foraminifers, invertebrates) and lithologic data, to establish the environment of deposition of the faunas and the changes in that environment with time. This information is then integrated into a largely foraminifer-based interpretation of the evolution of the Kerguelen Plateau. The time framework used is based on studies of the Cretaceous planktonic microfossils, especially foraminifers and calcareous nannoplankton (Quilty, this volume; Watkins, this volume). It supplements the results of Leg 119 (Barron, Larsen, et al., 1989).

Three sites drilled (Fig. 1) yielded Cretaceous sections from five holes for which I have documented the faunas: Holes $747 \mathrm{~A}$ and $747 \mathrm{C}$, Hole $748 \mathrm{C}$, and Holes $750 \mathrm{~A}$ and $750 \mathrm{~B}$.

\section{Previous Studies of Southern Hemisphere Cretaceous Benthic Foraminifers}

Very little is known about Cretaceous benthic foraminifers from the Kerguelen Plateau and its surroundings. Quilty recorded (1973) the Cenomanian-Turonian from Eltanin core E54-7 and revised (1984) some of the identifications, including the description of the genus Scheibnerova. Other dredging on the Kerguelen Plateau (Bassias et al., 1987) has recovered Cretaceous sediments, but no benthic foraminifers have been documented as yet.

The closest samples are from Deep Sea Drilling Project (DSDP) activity in the region (see Quilty, this volume, for a detailed review) and from dredging on the Naturaliste Plateau (Burckle et al., 1967). The latter paper referred to

\footnotetext{
${ }^{1}$ Wise, S. W., Jr., Schlich, R., et al., 1992, Proc. ODP, Sci. Results, 120: College Station, TX (Ocean Drilling Program).

2 Australian Antarctic Division, Channel Highway, Kingston, Tasmania, Australia, 7050.
}

benthic foraminifers, but none was discussed in detail, nor were figures given. Most detailed studies of DSDP material concentrated on the planktonic element, but several assemblages have been studied in detail, chiefly from older sediments (especially Aptian/Albian) by Scheibnerova $(1974,1978)$. Unfortunately, benthic forms from DSDP Sites 216 and 255 , sites that were nearer to the Kerguelen Plateau at the time of their accumulation, were not studied in detail.

Knowledge presently available indicates that provincialism was not absent, but does not appear to be a major concern in the distribution of Late Cretaceous deep-sea benthic foraminifers. Thus, many important forms documented by Cushman (1946) from the Gulf Coast region of the United States of America and Sliter (1968) from southern California and northwestern Mexico are also important in the Kerguelen Plateau region.

Belford's work (1958a, 1958b, 1959, and especially 1960) on Western Australian coastal Santonian/Campanian sections is especially relevant for studies at Sites 747 and 750 . Taylor (1964) documented marginal marine assemblages from the Santonian of Victoria (Australia) and his analysis was of value for the material recovered from Hole $748 \mathrm{C}$, which may have been deposited in a comparable environment.

Basov and Krasheninnikov (1983) reported in detail on the faunas from the South Atlantic Ocean, and their Santonian and younger sections contained calcareous faunas comparable with those recorded here. The faunas seem generally to represent deeper water environments with a higher content of characteristic agglutinated species. Their sections were much more affected by Carbonate Compensation Depth (CCD) variation than are those documented here. The upper Campanian-Maestrichtian section studied by Basov and Krasheninnikov contains many species in common with those recorded here but they were interpreted as lower bathyal, about $1000 \mathrm{~m}$ deeper than the Leg 120 sites.

Huber's review (1988) of the faunas from Seymour Island (Antarctic Peninsula) is relevant, particularly in relation to the faunas from Site 748 , because he studied a shallow-water section with a high detrital content. Sliter's study (1977) of southwestern Atlantic Ocean foraminifers is valuable be- 


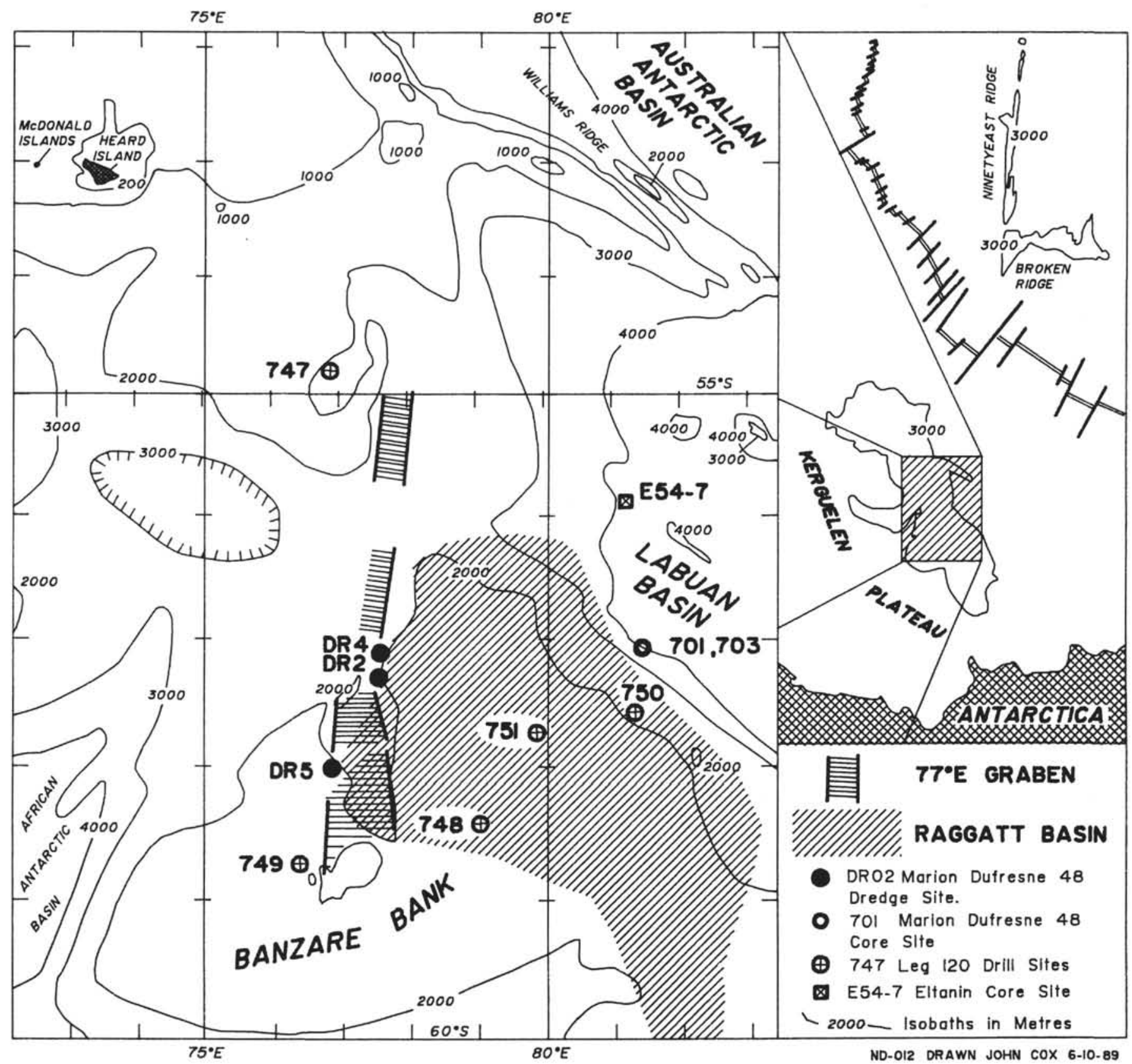

Figure 1. Location map, Southern Kerguelen Plateau, showing Leg 120 drill sites and major geological features of the region.

cause of its scope. His faunas are coeval with much of the section studied here, and, in addition, his study provided a comprehensive review of prior work. Malumian and Masiuk (1976) and Malumian et al. (1984) reported comparable faunas from southern South America. Much more basic documentation needs to be done on Southern Hemisphere faunas before definitive statements can be made regarding species identification, benthic foraminifer faunal provinces, depth associations, and, eventually, paleogeography of the region.

Because there is so little known about the benthic foraminifers of the region and because the faunas recorded here represent a wide range of environments, I have attempted to illustrate almost all forms seen, even if some of the material is not so well preserved and some of the identifications tentative.

\section{Materials and Methods}

Samples from Site 747 were processed by washing and passing through a $125 \mu \mathrm{m}$ sieve. They were then repeatedly halved until the sample size (planktonic and benthic) was about 300 specimens (200-700 approximately). This sample was used for counting. A few samples were subjected to this treatment several times before residues adequate for study were obtained.

Treatment for most samples from Hole $748 \mathrm{C}$ was different. Those from the upper part of the Cretaceous sequence are oozes or chalks, and the process outlined above generally was adequate. Samples from the deeper, more argillaceous and glauconitic section were treated with gasoline or kerosene. This consisted of crumbling the sample into fragments of approximately $5 \mathrm{~mm}$ in diameter, drying these in an oven at 
about $40^{\circ} \mathrm{C}$, cooling and covering with gasoline/kerosene for $24 \mathrm{hr}$, decanting and covering with water or a mixture of water and calgon. For most samples, one or two treatments were enough to reduce the sediment to mud, which was then sieved as described above. Normal gasoline treatment worked very well, but the results are not as clean generally as for samples from the clean carbonate sections and the statistics for foraminiferal faunas are not as good as for the other carbonate sections. Some very hard samples yielded to no treatment and were not studied.

Samples from the Cretaceous part of Subunit IIIA at Site 750 broke down successfully using simple washing and sieving as outlined above. A few more difficult samples were subjected to gasoline processing. The deeper section was uniformly much more indurated and required routine gasoline processing, which generally was successful. A few samples did not yield to this method.

The preservation of material from Site 747 is generally good. The site is now well above the CCD/lysocline and always has been; thus, no dissolution effects are obvious.

Preservation at Hole $748 \mathrm{C}$ generally is satisfactory and in some samples excellent, but many samples are characterized by a significant number of unidentifiable specimens or, for those left in open nomenclature, the result of poor initial preservation, more robust processing techniques, or the indurated nature of the sediment. In many samples, fine surface detail is rendered obscure by recrystallization or overgrowth. Rare samples have details obscured by silica overgrowths.

The difference in processing required for samples from Site 750 is reflected also in the preservation of the foraminifers. From Subunit IIIA preservation is good to excellent, but from the deeper subunits it is not as good, and from the lowest core (120-750B-11W), there are crushed specimens among what are otherwise satisfactory specimens. The difference in this core probably reflects the mixing of material from essentially coeval sources. One material is of white or pale consolidated chalk, and the other of dark gray or grayish brown calcareous siltstone, claystone, or marl. Specimens from the latter sediments seem to be those subject to crushing following compaction of the sediment during dewatering, whereas those from the paler chalk are preserved in their original shape.

\section{Bases for Paleobathymetric Interpretation}

Planktonic foraminifer faunas provide a general guideline as to water temperature, and the benthic faunas as to bathymetry. There is little evidence to indicate that any other factors have had a notable effect on faunal composition and structure, although winnowing caused by variations in current strength may have been a factor at times.

The paleobathymetric reconstructions developed in this study have been aided greatly by the work of Sliter (1972) and the compilation of van Morkhoven et al. (1986) for the Cenozoic and uppermost Cretaceous. Sliter referred to depth zones in terms of depth in meters (the part of the concept accepted as useful here), as well as in a shelf/slope geomorphic model. In contrast, van Morkhoven et al. (1986) referred to depth in the sense only of bathyal, abyssal, and other conditions, without defining a geomorphic model to which those depths correspond. The part of that approach that is very appropriate here is that relating to depth zones because the geomorphic concepts of shelf and slope are perhaps less applicable than on a continental margin of the type appropriate to the sections studied by Sliter (1972).

Walton (1964) analyzed the structure of modern foraminifer faunas from shallow waters of the Gulf of Mexico to develop a tool for paleoenvironmental interpretation in the region, a simple concept of dominance and diversity, the former being the percentage of the fauna made up by the most abundant species, and the latter the number of species constituting $95 \%$ of the fauna. The important generalizations to emerge from Walton's analysis were that, in faunas deposited on the upper continental shelf, high dominance and low diversity are usually associated with shallow-water faunas and decreasing dominance and increasing diversity with progressively deeper faunas. In sediments formed in an ooze environment, there are problems in obtaining benthic faunas numerous enough to give meaningful results; but in samples where there are more than 35-40 specimens of benthic forms, figures have been calculated and some consistent trends emerge. All faunas have been reduced to a theoretical 100 specimens for these calculations, using rarefaction (Sanders, 1968).

Walton's (1964) concept of dominance/diversity is more applicable to the section in Hole $748 \mathrm{C}$ than in deep-sea sections because the concept was developed for shallowwater sections. The figures were routinely calculated, even for deep-water sections, and are shown on the appropriate diagrams (Figs. 2-5).

Another figure routinely calculated and plotted is planktonic percentage, the percentage of a fauna consisting of planktonic specimens (e.g., Upshaw and Stehli, 1962). This is a useful, if rough, guide to water depths in sediments deposited above the CCD in Upper Cretaceous and Cenozoic sections.

\section{SITE 747}

Three holes (747A, 747B, and 747C) were drilled at this site at $54^{\circ} 48.66^{\prime} \mathrm{S} ; 76^{\circ} 47.64^{\prime} \mathrm{E}$ in a water depth of $1696-1707 \mathrm{~m}$. Cretaceous sediments were encountered in the interval 189.5295.1 meters below seafloor (mbsf), in Holes 747A (189.5-256 mbsf) and 747C (252-295.1 mbsf). Basalt underlies the sediment section.

Recovery was satisfactory for a record of species occurrence and interpretation of paleoenvironment (Schlich, Wise, et al., 1989). Cores $120-747 \mathrm{~A}-20 \mathrm{X}$ to $-22 \mathrm{X}$ overlap with $120-747 C-3 R$ to $-5 R$, but the former hole had better recovery and was used in this compilation.

Stratigraphic zonation of all sections (Table 1) is based on planktonic foraminifers and calcareous nannoplankton (Quilty, this volume; Watkins; this volume; Watkins et al., this volume). Benthic and planktonic faunas change markedly throughout the section, generally indicating that water was deepening with time.

Time has prevented the conduct of a detailed statistical analysis of the type undertaken by Sliter (1972) or Olsson and Nyong (1984). This approach would have been appropriate for comparative purposes because the age range covered is approximately the same although water depth at Site 747 usually was greater than for the section studied by Olsson and Nyong (1984).

\section{Faunal Structure and Its Paleoenvironmental Interpretation}

Nearly all faunas at Site 747 are dominated by planktonic forms (Fig. 2), (usually $>95 \%$ ), with two exceptions. The interval 220-235 mbsf has an erratic signal, with one number as low as $39 \%$. This interval probably represents winnowing and I propose that an interval of enhanced current activity occurred that caused a concentration of the more robust, denser benthic forms. The lower interval (290-272 mbsf; lower part of upper Campanian section and lower Santonian) of reduced planktonic percentage may well reflect shallower conditions of deposition as the Kerguelen Plateau commenced its descent. There is no evidence in the benthic faunas of any 
Table 1. Distribution of benthic species in samples from Holes 747 $\mathrm{A}$ and $747 \mathrm{~B}$.

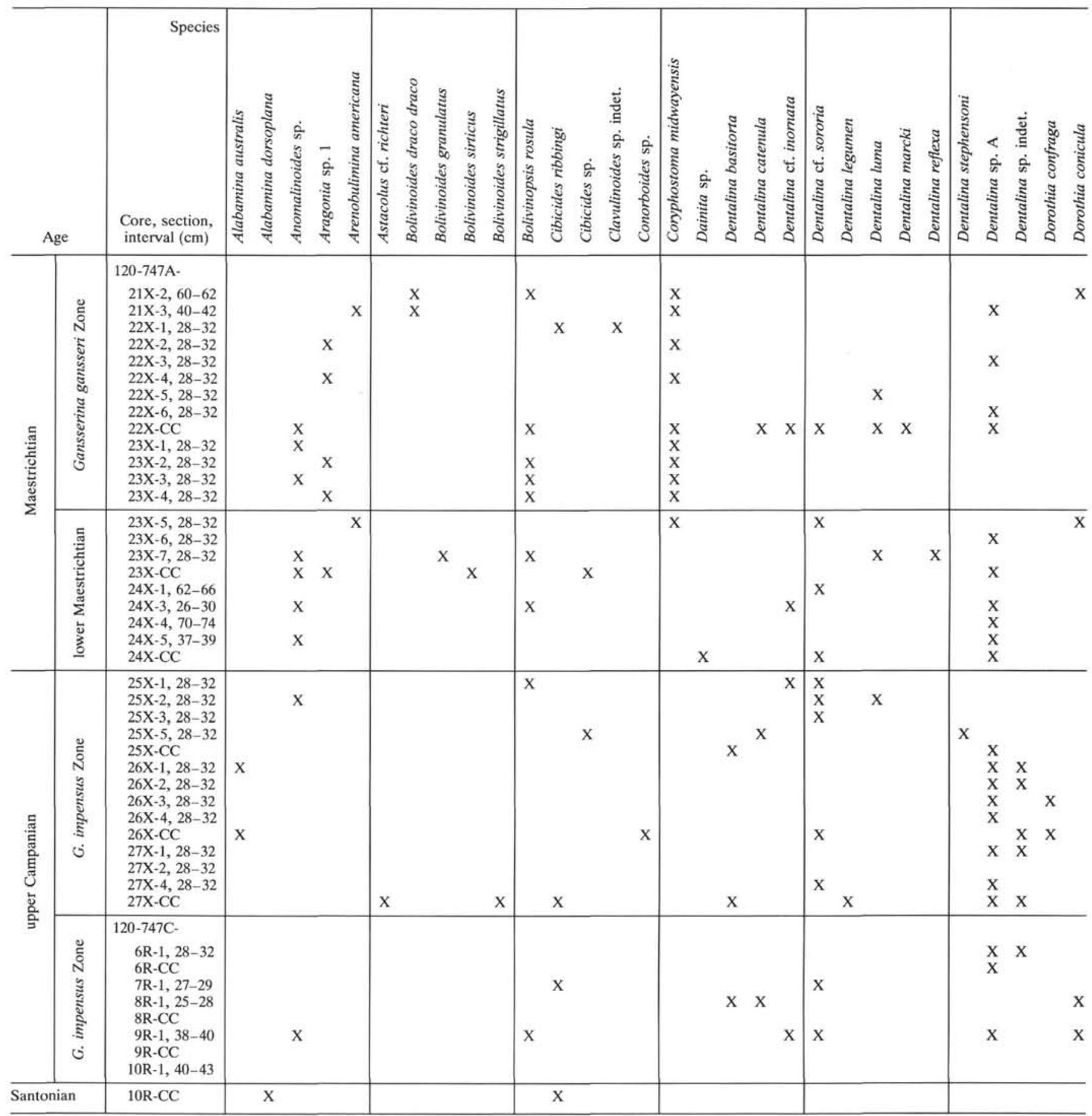

Notes: Numbers indicate the percentage of the fauna composed of each species; $\mathrm{X}=$ presence when percentage is $>1$, or when specimen numbers were too small for statistically significant percentages to be calculated; and $\mathrm{D}=$ dominant species in the fauna, even when the sample size is too small for statistical significance.

major fluctuation in depth, simply a consistent trend of depth increasing with time.

The material studied is included in lithologic Unit IV of nannofossil chalk and chert, except for a single lower Santonian sample (120-747C-10R-CC) that is coarser, contains glauconite, and represents deposition in a significantly shallower environment, perhaps with some turbulence. The lower Santonian fauna is poorly preserved and interpretation is difficult.

Throughout the rest of the section, Inoceramus is a minor to major component in some samples, especially the interval of Cores $120-747 \mathrm{~A}-23 \mathrm{X}$ to $-25 \mathrm{X}$ at the Campanian-Maestrichtian transition.

There are not many samples with enough benthic specimens to warrant any form of statistical analysis, resulting in long gaps on Figure 2.

No samples have a significant agglutinated foraminifer fauna; thus, the abyssal or lower slope depth environment is not represented. Similarly, there are no faunas that were obviously deposited at upper bathyal or shallower depths. Miliolids are very rare. 
Table 1 (continued).

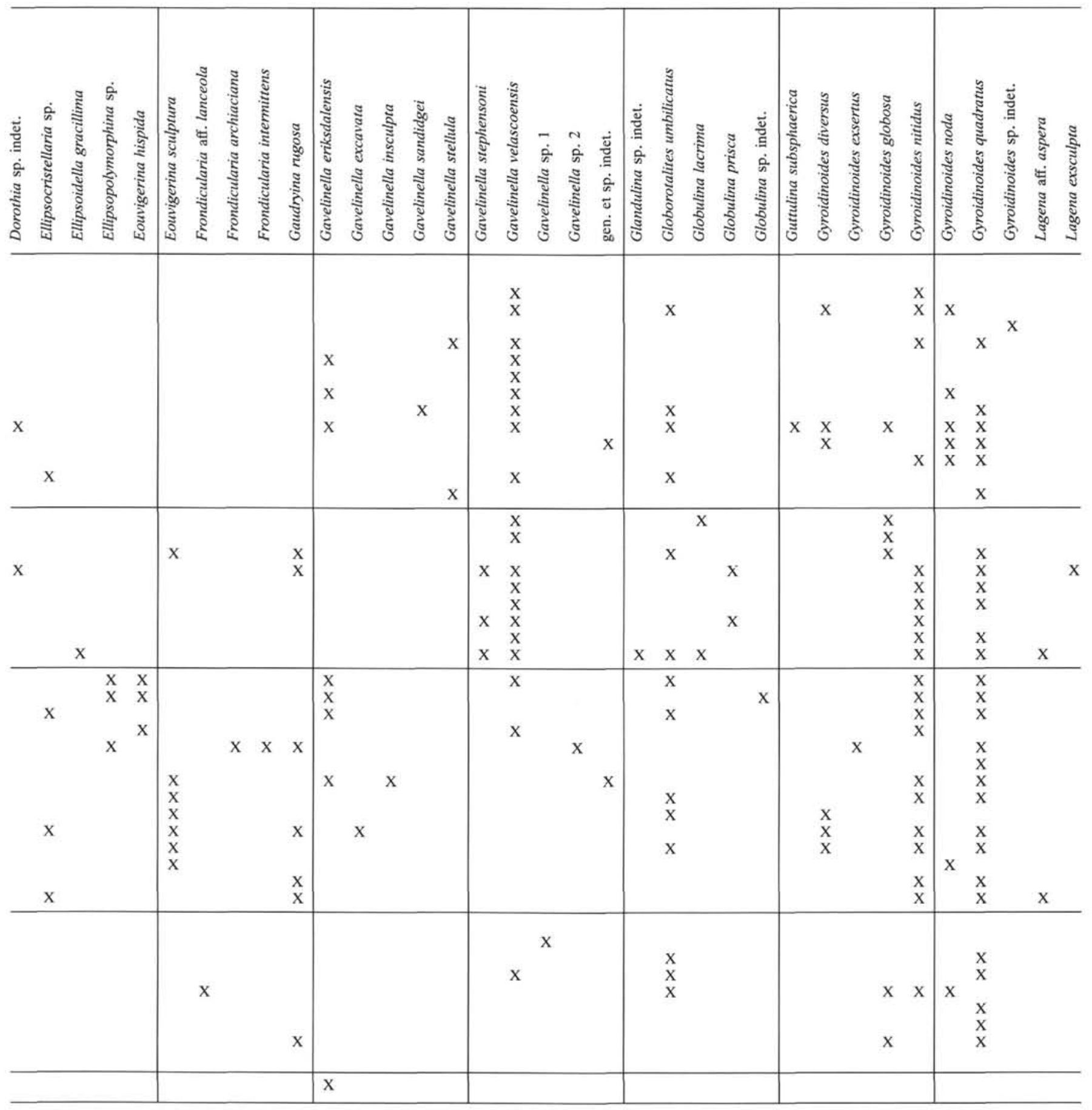

Stensioeina beccariiformis is usually dominant, except for the Santonian section where Gavelinella eriksdalensis is dominant, perhaps reflecting the shallower environment. In some samples, $S$. beccariiformis is not dominant; these are dominated by a variety of buliminid species, but without obvious trends or single key species. The dominance of $S$. beccariiformis holds true even when the number of specimens of benthic species is less than 35 and thus not statistically significant.

For the Cenozoic and uppermost Cretaceous, van Morkhoven et al. (1986) proposed that the consistent (though here as a small proportion of the faunas) presence of Coryphostoma midwayensis and Aragonia sp. 1 in the Maestrichtian section of Core 120-747A-23X and in younger cores indicates deposition in lower bathyal conditions (1000-2000 $\mathrm{m})$. All other occurrences in these faunas are consistent with that depth range, although there is evidence in the form of lower planktonic percentage, percentage of robust benthic species, considerable glauconite and a possible basalt gravel (site report for Site 747) that older sediments accumulated at shallower depth. Furthermore, there is no evidence to suggest 
Table 1 (continued).

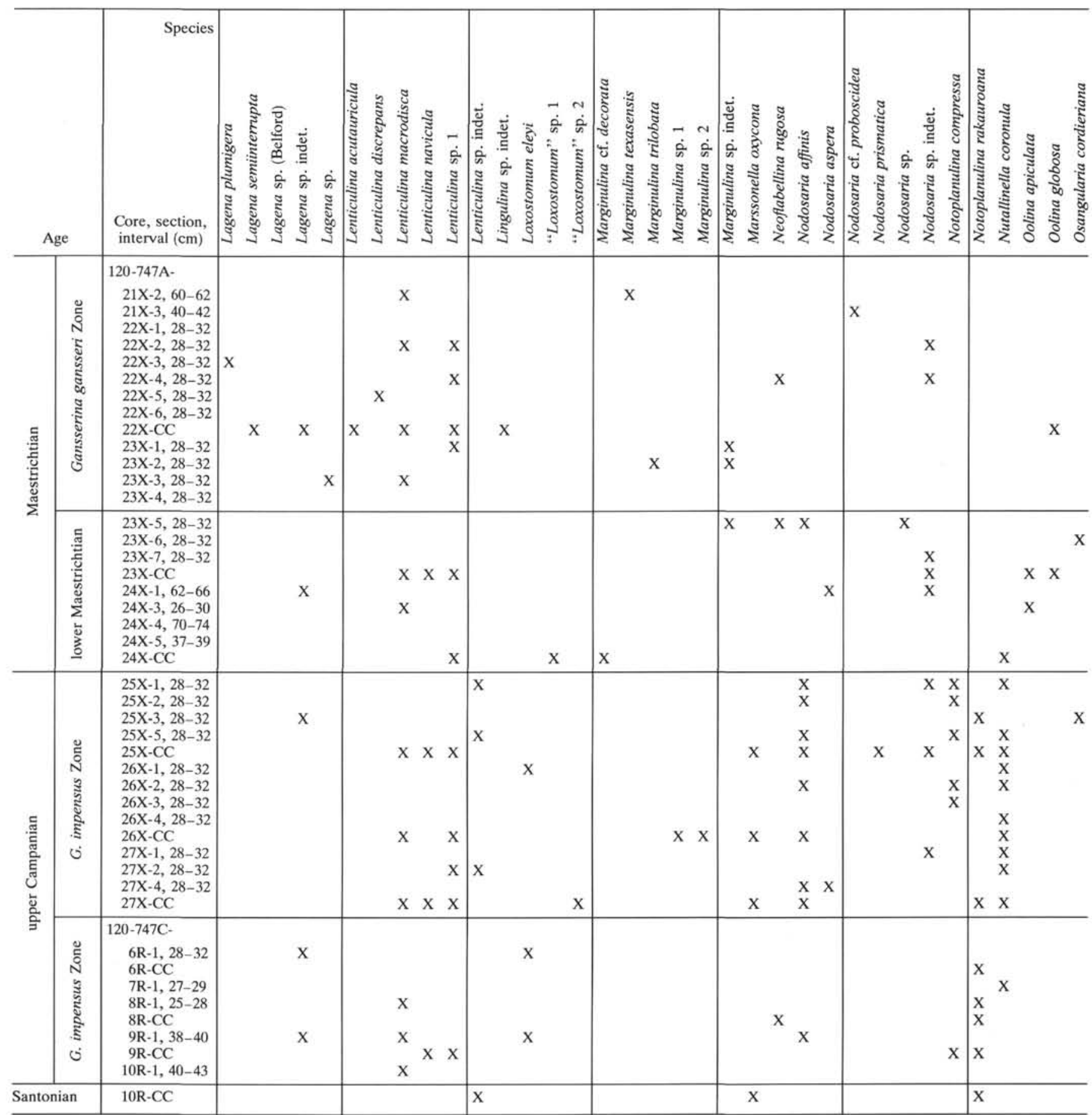

that tectonic activity led to deposition in the shallower part of the $1000-2000 \mathrm{~m}$ range.

Many of the species recorded here were documented by Sliter (1972) and used in his numerical analysis to identify paleobathymetrically significant species groups, each categorized by a letter of the alphabet. When dealing with the "dominant foraminifers in numerically defined sample groups" (Sliter, 1972), there are many species in common and many similar species can be recognized, even if the species composition of the faunas is not identical. Parallels with his Groups D ("water depths of about 850 m"- -as for his group
C) and E ("water depths of about $750 \mathrm{~m}$ ") faunas are particularly easily identified, with the Group E faunas slightly older (and shallower) than those of Group D.

In the lowest Maestrichtian (Core 120-747A-22X), and through the Campanian (to about Section 120-747A-18R-1), Gyroidinoides quadratus is a consistent and significant element of the faunas. Sliter (1972) interpreted this as approximately middle bathyal in the terms of van Morkhoven et al. (1986). The co-occurrence of a diverse array of species of Gyroidinoides and several species of Praebulimina and Gavelinella is consistent with and supports this interpretation. 
Table 1 (continued).

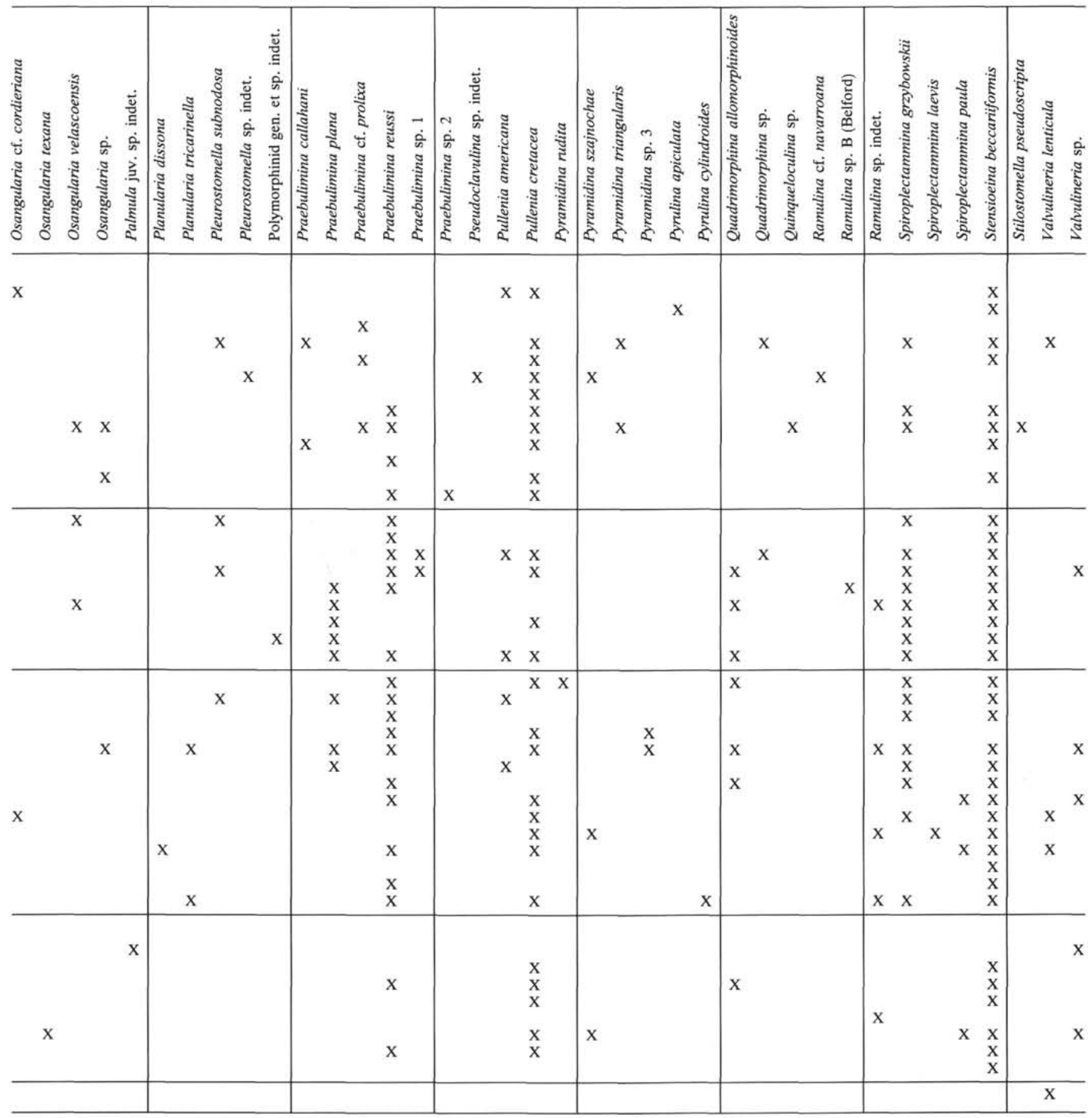

Present water depth is approximately $1700 \mathrm{~m}$, and probably this is the maximum depth that this site has reached. The Cretaceous sediments are dominantly oozes, and thus no shelf depths are indicated (except perhaps in the lower Santonian). Subsidence with time occurred at a rate greater than that of sedimentation, and the transition through the $1000 \mathrm{~m}$ isobath took place at about the Campanian/Maestrichtian boundary.

Disconformity is usual at the Cretaceous/Tertiary transition on the Southern Kerguelen Plateau, and there is evidence in the sediments of some tectonic activity at the end of the Cretaceous. There is no evidence in the foraminifer faunas of this section to suggest a changing depth regime consistent with the arching of the plateau referred to by Leclaire et al. (1987).

In summary, using the criteria outlined by Sliter (1972), the paleodepths at various times were as follows: early Santonian, middle bathyal (upper part); Campanian, middle bathyal (lower part); and Maestrichtian, lower bathyal (upper part).

\section{SITE 748}

Three holes were drilled at this site on the central part of the Plateau but only Hole $748 \mathrm{C}\left(58^{\circ} 26.45^{\prime} \mathrm{S}\right.$; $78^{\circ} 58.89^{\prime} \mathrm{E}$, in a water depth of $1301 \mathrm{~m}$ ) encountered a Cretaceous sequence. 


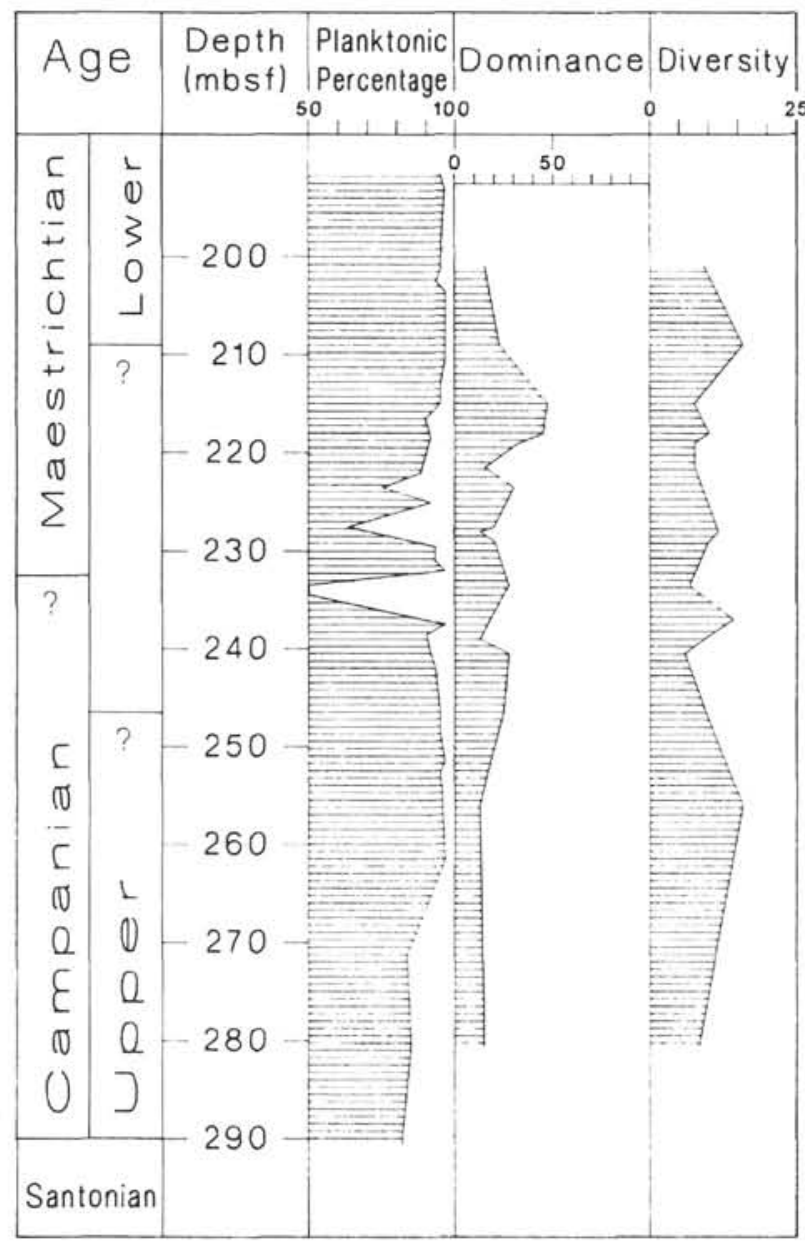

Figure 2. Planktonic percentage, dominance, and diversity results, Cretaceous marine section, Site 747.

The site was drilled to penetrate the Raggatt Basin sequence (Fig. 1), to identify the age and environment of deposition (particularly of the Paleogene and Cretaceous), and to add data on the tectonic history of this part of the Kerguelen Plateau. The site is drilled in much shallower water than the other sites.

The distribution of species recovered from Hole $748 \mathrm{C}$ is shown in Table 2, which also shows the stratigraphic zonation, based on various microfossil groups other than foraminifers. Planktonic foraminifers are rare and not useful at this site. Palynomorphs and calcareous nannofossils were more useful (Watkins, this volume; Mohr, this volume). The stratigraphic subdivision of the Cretaceous section at Site 748 on the accompanying figures is based on the summary by Watkins et al. (this volume).

The faunal composition and structure in Hole $748 \mathrm{C}$ are generally different from that in the other two Cretaceous sites and reflect sedimentation in an environment very different from those in nearby coeval sections or, for that matter, in environments normally encountered during deep sea drilling operations. Planktonic percentage usually is very low $(0 \%)$, but in a few samples from Subunit IIIA it reaches $45 \%$, much lower than elsewhere on Leg 120. Most of the section, although clearly marine, now contains no foraminifers at all. These factors, and others, suggest shallow-water sedimentation at inner-shelf depths.
In addition to the foraminifer-bearing samples documented on the accompanying range charts, many others were examined in detail, but yielded no foraminifers. Their distribution is shown in Table 3.

The Cretaceous sedimentary sequence (Cores 120-748C$27 R$ to $-79 R$ ) is entirely marine and incorporated into lithologic unit III, subdivided into Subunits IIIA through IIIC.

Subunit IIIA (397.4-711.0 mbsf, Cores 120-748C-25R to $-58 \mathrm{R})$ consists of glauconitic bioclastic grainstone to wackestone, intermittently silicified, with intervals rich in bryozoan debris, inoceramid prisms, and crinoid columns. It contains the unconformable Cretaceous/Tertiary contact at $407.0 \mathrm{mbsf}$, at the base of Core $120-748 \mathrm{C}-26 \mathrm{R}$. Thus, the Cretaceous part of Subunit IIIA lies in the section from 407.0 to $711.0 \mathrm{mbsf}$, a thickness of $304 \mathrm{~m}$.

The foraminifer faunas of this subunit are dominated by two species, usually Gavelinella sandidgei and Alabamina australis. The dominance of each of these species fluctuates strongly between samples but above 436 mbsf $G$. sandidgei usually is dominant; between 435 and $610 \mathrm{mbsf} A$. australis is dominant; and below that depth, $G$. sandidgei assumes ascendancy (sporadically exceeded by species of Gyroidinoides or Praebulimina). The degree of dominance is another index of the shallow-water origin of this sediment.

Subunit IIIB consists of glauconitic sandstone, siltstone, and claystone. It is compositionally similar to Subunit IIIA and includes abundant siliceous microfossils in places, but lacks bryozoans and significant silicification. There are sporadic bone and wood fragments throughout the subunit, which is underlain by a basaltic conglomerate with coarse mollusks that constitute Subunit IIIC. The stratigraphically highest wood fragments are from Sample 120-748C-61R-3, 79-81 cm. In Schlich, Wise, et al. (1989), Subunit IIIB is said to occur from 692.0 to 897.6 mbsf (Core 120-748C-57R to Section 120-748C-79R-4), a thickness of $205.6 \mathrm{~m}$. In this paper, Subunit IIIA is taken to the base of Core $120-748 \mathrm{C}-58 \mathrm{R}$ because the biogenic carbonate extends to that depth. The thickness is then taken to be $188.6 \mathrm{~m}$ and the top to be at 711 mbsf.

The only foraminifers recorded from this subunit are a few species of Saccammina from three samples (120-748C-61RCC, $-62 R-C C$, and $-63 R-C C)$. Subunit IIIC consists of a thin body of rounded basaltic cobbles with broken mollusk shells and a matrix akin to the lithology of the overlying subunit. Cut surfaces of the matrix were examined and seemed barren of foraminifers. No attempt was made to disaggregate samples from this subunit as it is too indurated and also quite thin. It contains sedimentological evidence (Schlich, Wise, et al., 1989) to suggest deposition in very shallow water marine conditions, perhaps even intertidal.

\section{Paleoenvironment}

The planktonic percentage figures, lithology, and accompanying fauna are all consistent with other evidence for deposition in a shallow marine environment throughout. Dominance is generally in the order of $40 \%$, with a trend toward a lower value with time, consistent with deepening or less varying conditions with time. As a corollary, diversity generally increases with time, in line with the trends observed by Walton (1964; Fig. 3). The dominance/diversity figures for the section shown in Figure 3 are shown in Figure 4. Simple statistical analysis shows a strong negative correlation between dominance and diversity indexes suggesting that the Walton approach has value in this instance. When the results plotted in Figure 4 are overlain on the summary made by Walton of all the samples he studied (Walton, 1964, fig. 26), they lie in the field of those that accumulated in less than 10 
fathoms, consistent with the planktonic percentage figures. This suggests that a strong parallel exists between the structures of modern and Cretaceous benthic foraminifer faunas, despite an age difference of up to $100 \mathrm{~m} . \mathrm{y}$.

Deposition at the site began during the upper Cenomanian, initially with Subunit IIIC consisting of coarse basaltic conglomerate with thick-shelled mollusks, now broken. This is consistent with the existence of a short period of high-energy, very shallow marine conditions, certainly above wave base, probably close to intertidal.

The presence of wood fragments, the virtual absence of foraminifers and calcareous nannofossils, the presence of abundant glauconite, and the lack of other marine indexes below Core $120-748 \mathrm{C}-61 \mathrm{R}$ in Subunit IIIB all support the hypothesis that deposition took place in long term shallow marine conditions, perhaps even estuarine or salt marsh, throughout the Cenomanian-Coniacian.

The upper section of Subunit IIIB yields evidence of changing conditions in the form of sponge spicules, radiolarians, shell fragments including Inoceramus, and very rarely agglutinated foraminifers such as Saccammina spp. Although still seemingly of very shallow-water aspect, the fauna suggests some oxygenation of the water above the sediment.

Virtually all of Subunit IIIB was deposited in a very shallow, generally low-energy, marine environment with a seafloor marked by reducing conditions at the surface or immediately below it. A modern analogy may be found in marine marshes or some estuarine environments.

The Cretaceous part of Subunit IIIA accumulated in shallow water, probably on the inner continental shelf. The planktonic percentage is very low, markedly different from that of coeval oozes on the plateau that, by analogy with other parts of the world, seem to represent bathyal depths and have planktonic percentages of $>90$, as would Cenozoic oozes from comparable environments of deposition. The continental shelf depth hypothesis is supported by the abundance of bryozoans, sometimes abraded by action within the reach of wave action. The presence of a hiatus representing $\sim 10 \mathrm{~m} . \mathrm{y}$. between this subunit and Subunit IIIB is also consistent, the gap perhaps caused by subaerial or possibly shallow marine erosion.

\section{SITE 750}

Two holes were drilled at this site at $57^{\circ} 35.54^{\prime} \mathrm{S}$; $81^{\circ} 14.37^{\prime} \mathrm{E}$, in water depth $2030.5 \mathrm{~m}$. Total penetration subsea was 709.7 mbsf and the Cretaceous marine section was recovered between 357.0 and approximately 623.5 mbsf. Site $750 \mathrm{~A}$ was continuously cored to the base of Core $120-750 \mathrm{~A}$ $26 \mathrm{R}$, at $460.5 \mathrm{mbsf}$ in upper Campanian sediments. Recovery was very poor below Core $120-750 \mathrm{~A}-21 \mathrm{R}$, and results, other than taxonomic, below that depth must be taken as tentative. Hole $750 \mathrm{~B}$ was not continuously cored, but a technique of wash-coring was improvised. The disadvantage of this technique in a section of poor recovery is that core location is very poorly controlled; for example, although convention would have it that Core $120-750 \mathrm{~B}-10 \mathrm{~W}$ represents the interval $566-$ 594.6 mbsf, the actual location within that depth range is unknown. Convention further records the sample as coming from the top of the core, in this case from the interval $566.0-567.2$ mbsf. The method of coring is strongly biased against soft sediment.

The Cretaceous/Tertiary boundary is at an unconformity of short duration with white nannofossil chalk above the Cretaceous. The marine section gives way downhole to a fluvial(?) unit of deep red claystone with siderite and wood fragments (Francis and Coffin, this volume). The nature of the contact between the marine and nonmarine sections is unknown.
The Cretaceous marine section is incorporated into lithologic Unit III, which was divided into Subunits IIIA, IIIB, and IIIC. Unit III is characterized by nannofossil chalk, chert, and intermittently silicified limestone. Subunit IIIA (357-450 mbsf) consists of nannofossil chalk with minor chert; Subunit IIIB (450-594.6 mbsf), of intermittently silicified limestone with some macrofauna; and Subunit IIIC (594.6-623.5 mbsf), of chalk with dark clayey interlayers. Recovery and thus the results are better for Subunit IIIA than for the others.

The distribution of foraminifers identified from this section is shown on Table 4, and the planktonic percentage, dominance and diversity are shown in Figure 5.

Faunas from samples shallower than Core 120-750A-20R within Subunit IIIA are consistent in structure and commonly dominated by Stensioeina beccariiformis and various other species including species of Gyroidinoides, Praebulimina, and Gavelinella. Gavelinella velascoensis is a common component.

Samples from Cores 120-750B-4W to -10W (Subunit IIIB) contain faunas that vary from very poor to moderately preserved. Some contain only a few specimens but others yielded satisfactory numbers of specimens. The dominant species and genera vary widely from sample to sample and no consistent trend has emerged. The dominant genera include Gavelinella, Gyroidinoides, Globorotalites, and Praebulimina. Nuttallinella florealis (White) occurs in Core 120-750B-46W. In some samples there is a considerable proportion of agglutinated species. Gavelinella eriksdalensis occurs only sporadically throughout the section and is dominant only in two samples. Stensioeina sp. 1 occurs sporadically in the section but is never dominant.

Rapid faunal change can be illustrated by the contrast between the faunal structure in Sample 120-750B-10W-1, 60 $\mathrm{cm}$, and that in other samples from the same section. That in the former is dominated strongly by Gavelinella eriksdalensis and a variety of species of Gyroidinoides in addition to Notoplanulina compressa. Praebulimina is absent, apparently a primary feature rather than the fault of diagenesis. Other faunas in this interval contain diverse arrays of Praebulimina although the diversity is between samples, not so much within individual samples. The genus is seldom dominant.

Within the cored earliest marine sediments of Subunit IIIC, there are two lithologies, both carbonate-rich, but one darker with a considerable fine-grained detrital component. They are mixed as discrete, thinly bedded strata with parallel bedding that sometimes contains evidence of disturbance by bioturbation. If bioturbation did occur at the time of sedimentation, buckled beds could be expected. Generally they are not, and in places they are broken as if brittle. Within one core sample, bedding units stop abruptly and give way to the other lithology. The control is only a matter of speculation. There is no evidence in the faunas from the two lithologic types of any age difference or of any difference in water temperature or salinity during deposition. The paler material has a higher planktonic foraminifer percentage and lower content of agglutinated benthic forms. The darker material has a low planktonic content, has a more diverse benthic fauna with significant agglutinated content and sporadically contains spores and small wood fragments. Because of these peculiarities, several samples were examined from a short core interval near the base of the marine section (Table 4). Much remains to be learned of the early history at this site and of the depositional conditions of the various sedimentary units.

In addition to the samples processed from the core material, a soft, dark mud was recovered from the surface of Core $120-750 \mathrm{~B}-11 \mathrm{~W}$. On washing, this mud sample yielded the only Cenomanian marine fauna positively identified on the basis of 
Table 2. Distribution of benthic species in samples from Hole $\mathbf{7 4 8 C}$.

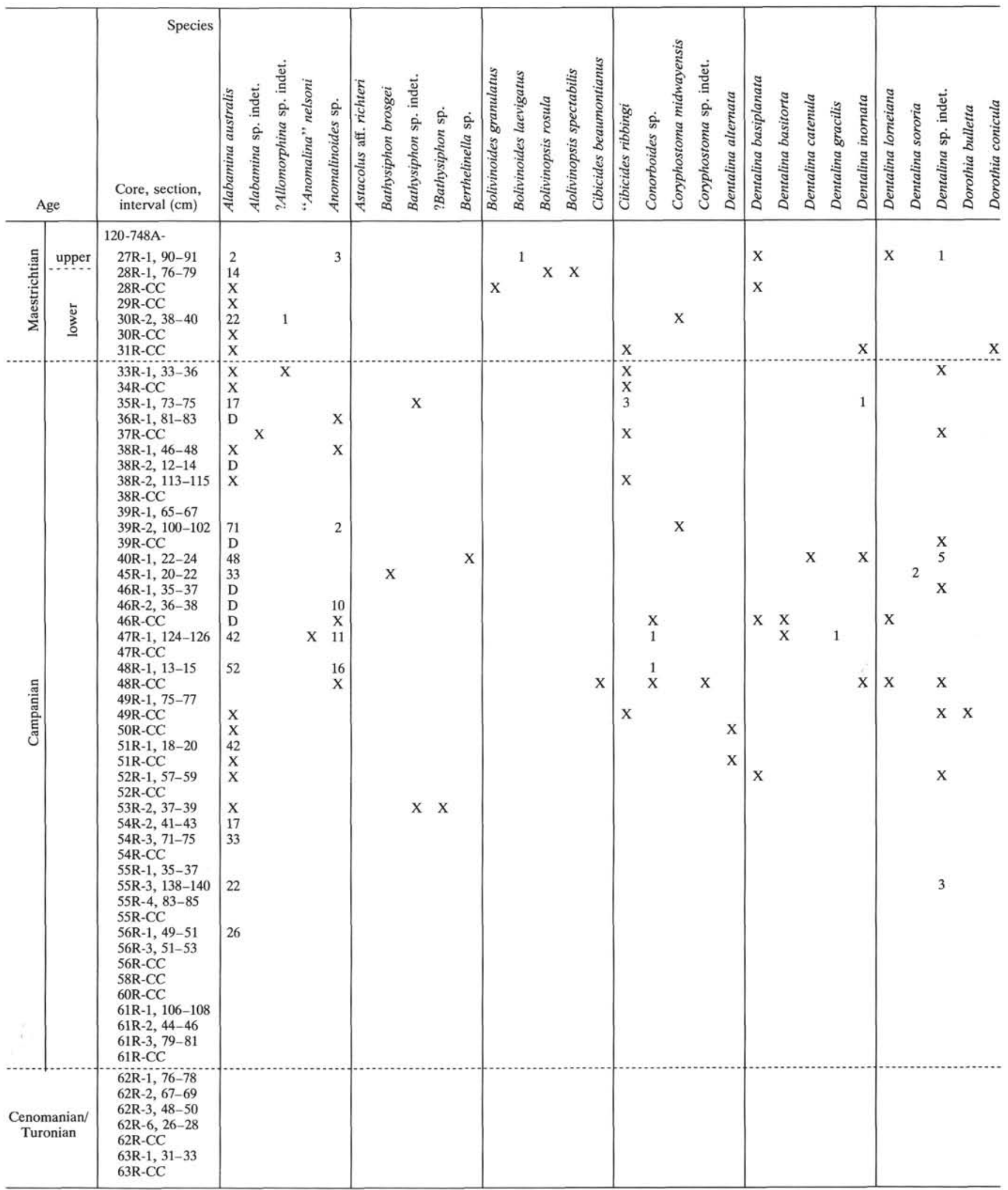

Note: See note to Table 1 for an explanation of the symbols used in the table. 
Table 2 (continued).

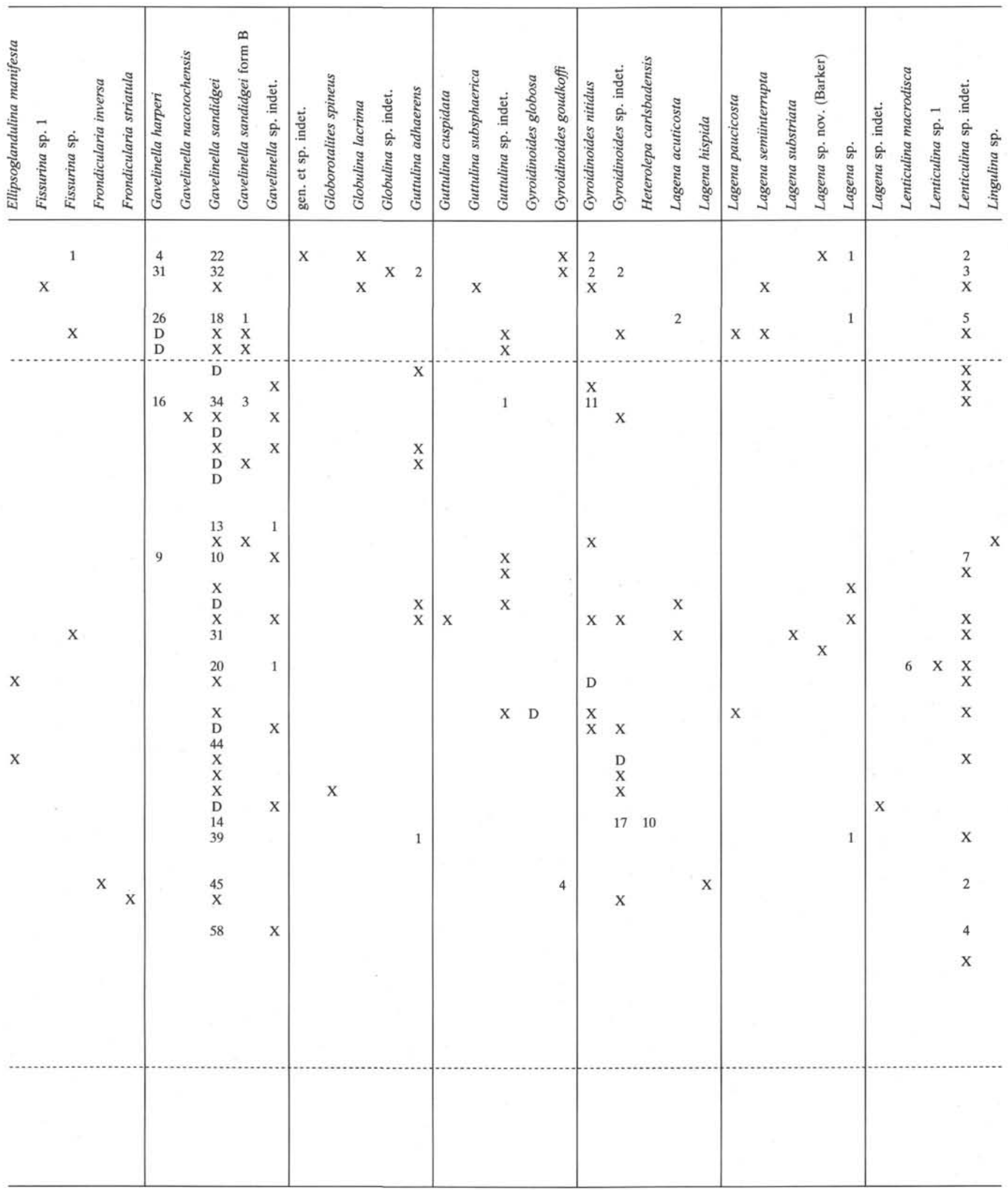


Table 2 (continued).

\begin{tabular}{|c|c|c|c|c|c|c|c|c|c|c|c|c|c|c|c|c|c|c|c|c|c|c|c|c|c|c|c|}
\hline \multicolumn{2}{|c|}{ Age } & $\begin{array}{l}\text { Species } \\
\text { Core, section, } \\
\text { interval }(\mathrm{cm})\end{array}$ & 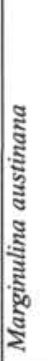 & 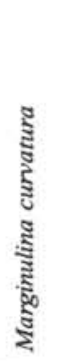 & 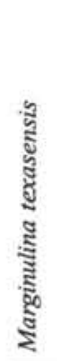 & 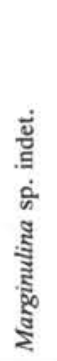 & 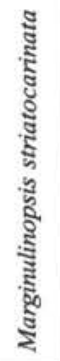 & 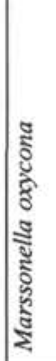 & 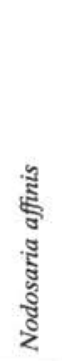 & $\begin{array}{l}\text { sूँ } \\
\frac{5}{2} \\
\frac{5}{5} \\
\frac{5}{5} \\
\frac{8}{2}\end{array}$ & 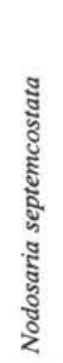 & 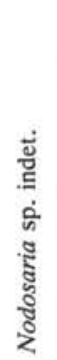 & 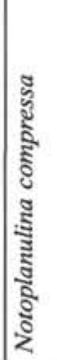 & 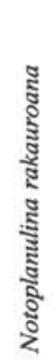 & 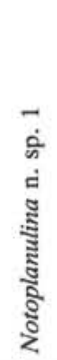 & 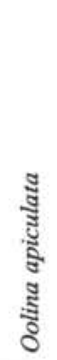 & 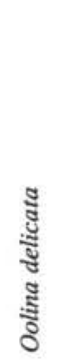 & $\begin{array}{l}5 \\
5 \\
0 \\
0 \\
0 \\
0 \\
5 \\
0 \\
0\end{array}$ & 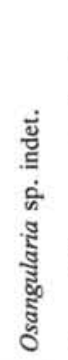 & 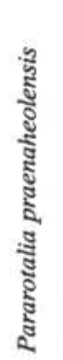 & 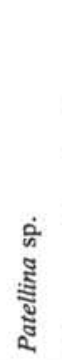 & 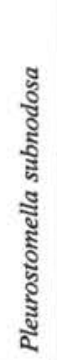 & 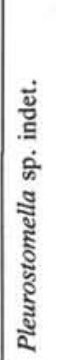 & 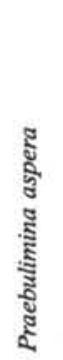 & 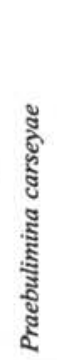 & 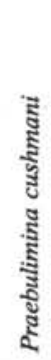 & 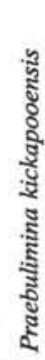 \\
\hline 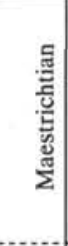 & upper & $\begin{array}{l}120-750 \mathrm{~A}- \\
27 \mathrm{R}-1,90-91 \\
28 \mathrm{R}-1,76-79 \\
28 \mathrm{R}-\mathrm{CC} \\
29 \mathrm{R}-\mathrm{CC} \\
30 \mathrm{R}-2,38-40 \\
30 \mathrm{R}-\mathrm{CC} \\
31 \mathrm{R}-\mathrm{CC}\end{array}$ & & & & 1 & & & & & & $\begin{array}{l}6 \\
\mathrm{x}\end{array}$ & 3 & $\begin{array}{l}\mathrm{X} \\
\mathrm{X} \\
\mathrm{X}\end{array}$ & $\mathrm{X}$ & & & $x$ & $X$ & & & $\mathrm{X}$ & $\mathrm{X}$ & & 45 & $\begin{array}{l}X \\
x\end{array}$ & \\
\hline 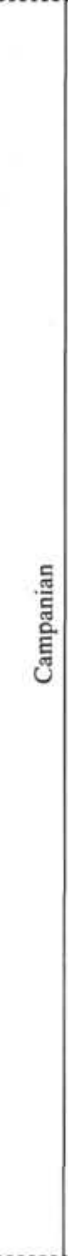 & & $\begin{array}{l}33 \mathrm{R}-1,33-36 \\
34 \mathrm{R}-\mathrm{CC} \\
35 \mathrm{R}-1,73-75 \\
36 \mathrm{R}-1,81-83 \\
37 \mathrm{R}-\mathrm{CC} \\
38 \mathrm{R}-1,46-48 \\
38 \mathrm{R}-2,12-14 \\
38 \mathrm{R}-2,113-115 \\
38 \mathrm{R}-\mathrm{CC} \\
39 \mathrm{R}-1,65-67 \\
39 \mathrm{R}-2,100-102 \\
39 \mathrm{R}-\mathrm{CC} \\
40 \mathrm{R}-1,22-24 \\
45 \mathrm{R}-1,20-22 \\
46 \mathrm{R}-1,35-37 \\
46 \mathrm{R}-2,36-38 \\
46 \mathrm{R}-\mathrm{CC} \\
47 \mathrm{R}-1,124-126 \\
47 \mathrm{R}-\mathrm{CC} \\
48 \mathrm{R}-1,13-15 \\
48 \mathrm{R}, \mathrm{CC} \\
49 \mathrm{R}-1,75-77 \\
49 \mathrm{R}-\mathrm{CC} \\
50 \mathrm{R}-\mathrm{CC} \\
51 \mathrm{R}-1,18-20 \\
51 \mathrm{R}-\mathrm{CC} \\
52 \mathrm{R}-1,57-59 \\
52 \mathrm{R}-\mathrm{CC} \\
53 \mathrm{R}-2,37-39 \\
54 \mathrm{R}-2,41-43 \\
54 \mathrm{R}-3,71-75 \\
54 \mathrm{R}-\mathrm{CC} \\
55 \mathrm{R}-1,35-37 \\
55 \mathrm{R}-3,138-140 \\
55 \mathrm{R}-4,83-85 \\
55 \mathrm{R}-\mathrm{CC} \\
56 \mathrm{R}-1,49-51 \\
56 \mathrm{R}-3,51-53 \\
56 \mathrm{R}-\mathrm{CC} \\
58 \mathrm{R}-\mathrm{CC} \\
60 \mathrm{R}-\mathrm{CC} \\
61 \mathrm{R}-1,106-108 \\
61 \mathrm{R}-2,44-46 \\
61 \mathrm{R}-3,79-81 \\
61 \mathrm{R}-\mathrm{CC} \\
\end{array}$ & $\mathrm{X}$ & $x$ & 1 & $\begin{array}{l}X \\
X \\
X \\
X\end{array}$ & $\mathrm{x}$ & $\begin{array}{l}1 \\
3 \\
3 \\
X \\
\\
\\
x\end{array}$ & $\begin{array}{l}5 \\
\mathrm{X} \\
2 \\
\mathrm{X} \\
\mathrm{X} \\
\mathrm{X}\end{array}$ & $X$ & $x$ & $\begin{array}{l}\mathrm{X} \\
\mathrm{X}\end{array}$ & $\begin{array}{l}46 \\
X\end{array}$ & $\begin{array}{l}\mathrm{X} \\
3 \\
\mathrm{X}\end{array}$ &. & $\mathrm{X}$ & $X$ & - & & $\begin{array}{l}X \\
X\end{array}$ & $\begin{array}{l}X \\
X\end{array}$ & & $X$ & $X$ & $\begin{array}{l}X \\
X \\
\\
21 \\
19\end{array}$ & . & $\mathrm{X}$ \\
\hline $\begin{array}{l}\text { Cenon } \\
\text { Tur }\end{array}$ & $\begin{array}{l}\text { manian/ } \\
\text { onian }\end{array}$ & $\begin{array}{l}62 \mathrm{R}-1,76-78 \\
62 \mathrm{R}-2,67-69 \\
62 \mathrm{R}-3,48-50 \\
62 \mathrm{R}-6,26-28 \\
62 \mathrm{R}-\mathrm{CC} \\
63 \mathrm{R}-1,31-33 \\
63 \mathrm{R}-\mathrm{CC}\end{array}$ & & & & & & & & & & & & ; & & & & & & & & & & & , & & \\
\hline
\end{tabular}




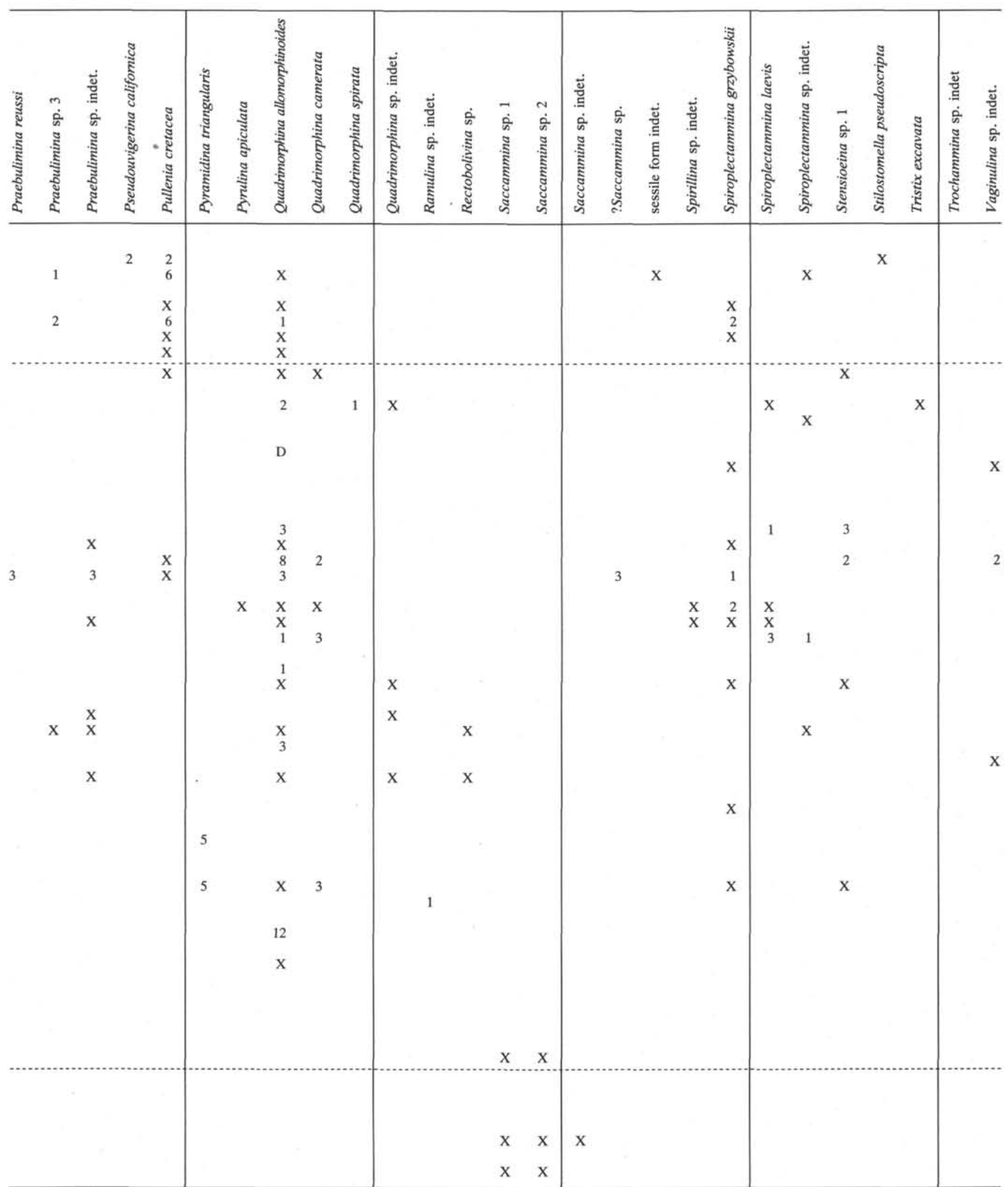


Table 3. Samples from Hole $748 \mathrm{C}$ that are barren of foraminifers.

\begin{tabular}{|c|c|}
\hline $\begin{array}{l}\text { Hole, core, section, } \\
\text { interval }(\mathrm{cm})\end{array}$ & $\begin{array}{l}\text { Depth } \\
\text { (mbsf) }\end{array}$ \\
\hline \multicolumn{2}{|l|}{$120-748 \mathrm{C}$ - } \\
\hline $64 \mathrm{R}-2,41-42$ & 753.41 \\
\hline $64 \mathrm{R}-3,41-42$ & 754.91 \\
\hline $64 \mathrm{R}-4,41-42$ & 756.41 \\
\hline 64R-CC & 761.0 \\
\hline $65 \mathrm{R}-1,41-43$ & 761.41 \\
\hline 65R-CC & 770.5 \\
\hline $66 \mathrm{R}-1,41-43$ & 770.91 \\
\hline 66R-CC & 780.0 \\
\hline $67 \mathrm{R}-1,64-66$ & 780.64 \\
\hline 67R-CC & 789.5 \\
\hline $68 \mathrm{R}-1,46-48$ & 789.46 \\
\hline $69 \mathrm{R}-1,40-42$ & 797.9 \\
\hline $69 \mathrm{R}-2,42-44$ & 799.42 \\
\hline $69 \mathrm{R}-\mathrm{CC}$ & 807.0 \\
\hline $70 R-1,59-61$ & 807.59 \\
\hline 70R-2, 59-61 & 809.09 \\
\hline $70 R-3,59-61$ & 810.59 \\
\hline $70 R-4,59-61$ & 812.09 \\
\hline $70 \mathrm{R}-5,58-60$ & 813.58 \\
\hline 70R-CC & 816.5 \\
\hline 71R-1, 59-61 & 817.09 \\
\hline $71 \mathrm{R}-2,59-61$ & 818.59 \\
\hline $71 \mathrm{R}-3,59-61$ & 820.09 \\
\hline $71 \mathrm{R}-4,59-61$ & 821.59 \\
\hline $71 \mathrm{R}-5,59-61$ & 823.09 \\
\hline $71 \mathrm{R}-6,59-61$ & 824.59 \\
\hline 71R-CC & 826.5 \\
\hline $72 \mathrm{R}-1,61-63$ & 827.11 \\
\hline $72 \mathrm{R}-2,61-63$ & 828.61 \\
\hline $72 \mathrm{R}-3,61-63$ & 830.11 \\
\hline $72 R-4,61-63$ & 831.61 \\
\hline $72 \mathrm{R}-\mathrm{CC}$ & 835.5 \\
\hline $73 \mathrm{R}-1,21-22$ & 835.71 \\
\hline $73 R-1,67-69$ & 836.17 \\
\hline $73 \mathrm{R}-2,47-49$ & 837.97 \\
\hline $73 R-2,117-119$ & 838.17 \\
\hline $73 R-3,56-57$ & 839.06 \\
\hline $73 R-5,20-22$ & 841.7 \\
\hline $73 R-5,38-40$ & 841.88 \\
\hline $73 R-6,23-25$ & 843.23 \\
\hline $73 \mathrm{R}-6,126-129$ & 844.26 \\
\hline $73 \mathrm{R}-7,22-23$ & 844.72 \\
\hline 73R-CC & 845.0 \\
\hline $74 \mathrm{R}-1,37-39$ & 845.37 \\
\hline $74 \mathrm{R}-1,113-115$ & 846.13 \\
\hline $74 \mathrm{R}-2,140-142$ & 847.9 \\
\hline $74 \mathrm{R}-4,52-54$ & 850.02 \\
\hline $74 \mathrm{R}-5,38-40$ & 851.38 \\
\hline $74 \mathrm{R}-\mathrm{CC}$ & 854.5 \\
\hline $75 \mathrm{R}-1,122-124$ & 855.72 \\
\hline $75 \mathrm{R}-2,123-125$ & 857.23 \\
\hline $75 \mathrm{R}-3,130-132$ & 858.8 \\
\hline $75 R-4,145-147$ & 860.45 \\
\hline $75 R-5,146-150$ & 861.96 \\
\hline $75 \mathrm{R}-6,71-75$ & 862.71 \\
\hline 75R-CC & 864.0 \\
\hline $76 \mathrm{R}-1,102-106$ & 865.02 \\
\hline $76 \mathrm{R}-3,99-103$ & 867.99 \\
\hline $76 \mathrm{R}-\mathrm{CC}$ & 873.5 \\
\hline $77 \mathrm{R}-\mathrm{CC}$ & 883.0 \\
\hline $78 \mathrm{R}-2,85-87$ & 885.35 \\
\hline $78 \mathrm{R}-3,130-133$ & 887.3 \\
\hline $78 \mathrm{R}-4,57-59$ & 888.07 \\
\hline $78 R-5,34-37$ & 889.34 \\
\hline $78 \mathrm{R}-6,24-27$ & 890.74 \\
\hline $78 \mathrm{R}-\mathrm{CC}$ & 892.5 \\
\hline $79 R-5,9-10$ & 898.59 \\
\hline 79R-CC & 902.0 \\
\hline $85 \mathrm{R}-\mathrm{CC}$ & 927.5 \\
\hline 87R-CC & 935.0 \\
\hline
\end{tabular}

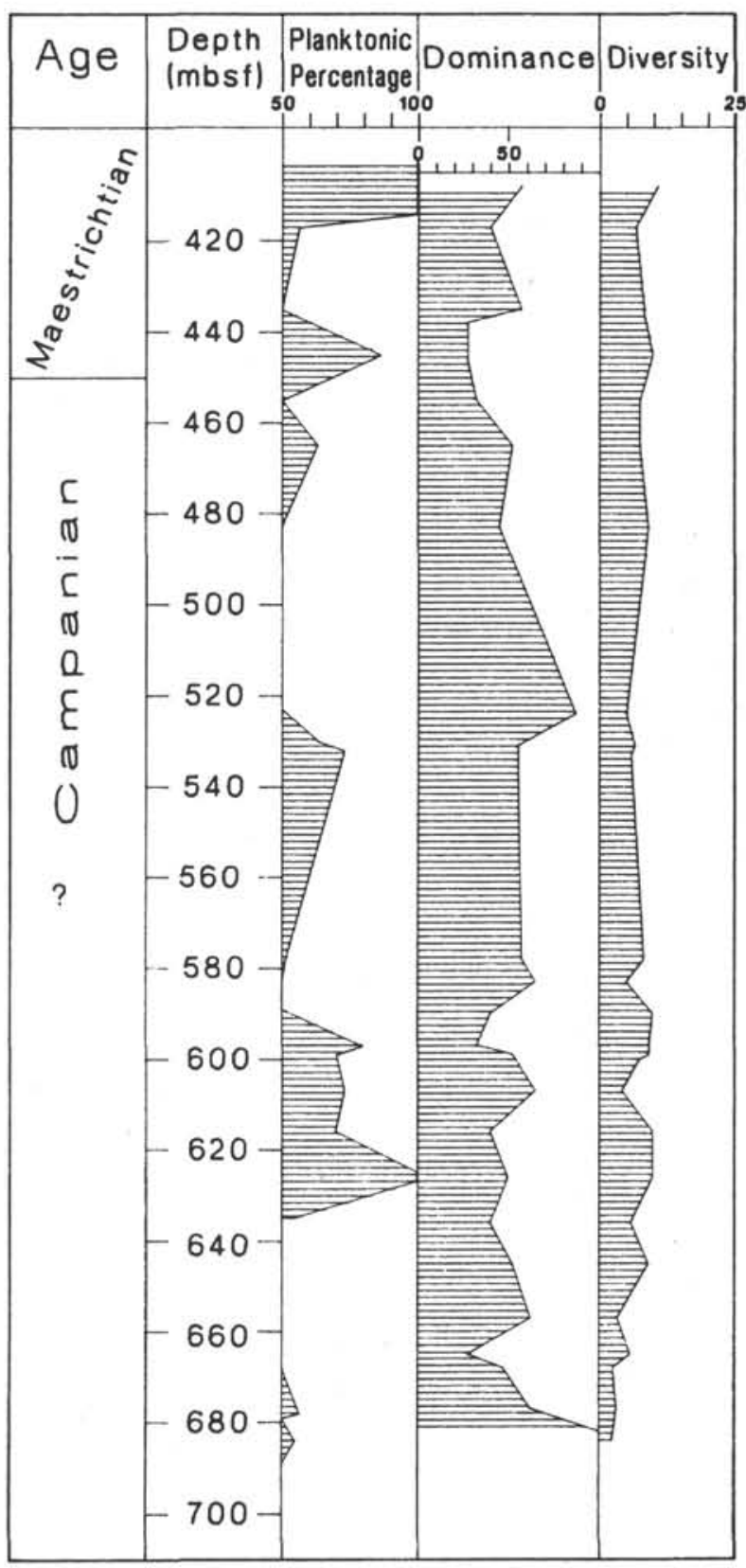

Figure 3. Planktonic percentage, dominance, and diversity results, Cretaceous marine section, Site 748.

planktonic foraminifers (Quilty, this volume). The source and lithology of this material is unknown and only a few cubic millimeters were found. It comes from the interval 594.6$623.5 \mathrm{mbsf}$. This sediment implies that there is a considerable amount of unsampled soft sediment in the section drilled.

\section{Paleoenvironment}

As for other Leg 120 sites, there is clear evidence in this hole for increasing water depth with time. Sedimentation at the site began in fluvial, perhaps flood-plain conditions in surroundings inhabited by considerable vegetation (Francis and Coffin, this volume). At the base of the marine section (623.5 mbsf; Core 120-750B-11W), there is evidence of continental shelf (even inner continental shelf) depth environment of deposition. This is consistent with a transition from the 


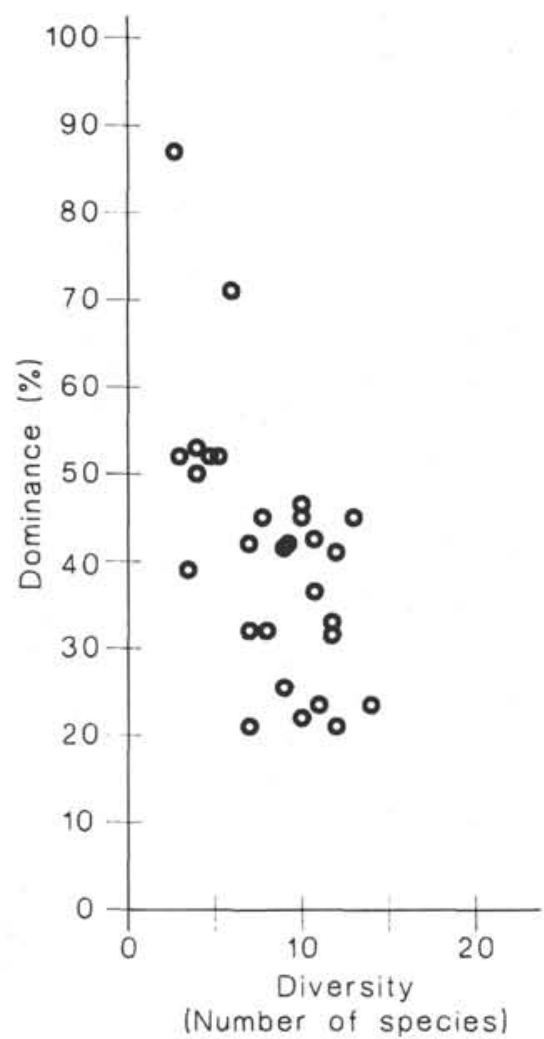

Figure 4. Dominance and diversity data, Cretaceous marine section, Site 748.

fluvial environment (represented by the reddish sediments below) to the marine sometime early in the Cenomanian or even earlier.

The pale calcareous lithology of Subunit IIIC is taken as representing the normal sediment being deposited at the site of accumulation, and the darker lithology as accumulating in a shallower water environment elsewhere (perhaps an inner shelf muddy environment). This periodically slumped or was otherwise moved into the deeper water ooze environment, perhaps still within continental shelf depth.

As a stratigraphic section, Subunit IIIB of the column at Site 750 is the least satisfactory for meaningful paleoenvironmental interpretation. The composition of faunas in Subunit IIIB is analogous variously with Faunas D, E, or F of Sliter (1972). Gyroidinoides spp. are common and diverse. The data can be interpreted as indicating rapid fluctuations of environment, as suggested by marked differences from sample to sample of faunal content, but no simple trend emerges from that analysis. The fauna from Sample 120-750B-10W-1, $60 \mathrm{~cm}$, based on the dominance by $G$. eriksdalensis, can be taken as indicative of Sliter's Fauna E and a depth of deposition within the depth interval of 700 and $800 \mathrm{~m}$. The environment represented by samples deeper than Core $120-750 \mathrm{~B}-10 \mathrm{~W}$ seems to have been shallower and those above it considerably deeper, perhaps middle to upper slope depths on the order of 500-800 $\mathrm{m}$. A simple approach is to suggest that this interval was the time at which depth changed from shelf to slope although, as pointed out earlier, this is a depth, not a geomorphic judgment. The presence of small numbers of Nuttallinella florealis (White) in Core $120-750 \mathrm{~B}-6 \mathrm{~W}$ is consistent with this hypothesis and suggests that from that time on the waters were deeper than continental shelf. The increased diversity of species of
Praebulimina in Core $120-750 \mathrm{~B}-4 \mathrm{~W}$ and shallower is consistent also with the concept of deepening water. The rapid changes in fauna may reflect environmental changes that are controlled not so much by depth as by other factors, such as changing current patterns over the deepening Kerguelen Plateau.

Comparison of Subunit IIIA faunas with the scheme of Sliter (1968) is not easy, but a general correlation with his middle to upper slope Faunas D, E, and F is evident, perhaps reflecting water depths of $650-850 \mathrm{~m}$, although those limits are approximate.

In summary, the paleobathymetric environment at Site 750 is difficult to interpret, but seems to have changed from shallow shelf to middle or upper bathyal between the Cenomanian and Maestrichtian. Neither the time of change nor the bathymetric progress is easy to define, however. Unfortunately, there is no way to analyze the environment during the upper Cenomanian, which is very poorly represented in the hole. The progress to the considerably greater modern depth probably was a Tertiary phenomenon.

\section{Regional Paleogeography}

Understanding of the paleogeographic evolution of the area is still in its infancy. The Kerguelen Plateau is now a high-latitude site, and sites drilled during Leg 120 are in the modern latitude range $58^{\circ}-59^{\circ} \mathrm{S}$. During the Cretaceous, this was not the case and some reconstructions suggest that the Cretaceous paleolatitude was quite variable with time from middle to high latitude. The following paleolatitudes are derived from figures in Smith et al. (1981), assuming that the Kerguelen Plateau has maintained a constant relationship to Antarctica and that the epoch ages given by Smith et al. (1981) are more correct than the age as expressed in "absolute" terms.

\begin{tabular}{lrc}
\hline \multicolumn{1}{c}{ Age } & Ma & Latitude $\left({ }^{\circ} \mathrm{S}\right)$ \\
\hline Paleocene & 60 & 67 \\
Santonian & 80 & 59 \\
early Cenomanian & 100 & 47 \\
\hline
\end{tabular}

Other data (Sclater et al., 1977) would suggest that the same area was at $51^{\circ} \mathrm{S}$ at Anomaly 32 time (early Maestrichtian; $73 \mathrm{Ma}$ ). Veevers et al. (1984) indicated that the paleolatitude for the region seems to have been constant $\left( \pm 2^{\circ}-3^{\circ}\right)$ over the Cenomanian and younger interval, but perhaps farther north before that time.

Results at Sites 747 and 750 are consistent with the postulate of a rapid subsidence of the plateau soon after its initial formation. Thus, it is probable, even without the evidence given here, that sedimentation in the Campanian/ Maestrichtian occurred at depths ranging from 200 to 1500 $\mathrm{m}$. Although these depths are continental slope depths, geomorphically the region was a plateau rather than a slope. Sedimentation on this feature was perhaps influenced at times by the geomorphology of the Kerguelen Plateau, which now, and probably also then, acted as a shallow barrier over which currents from the west had to pass. It is not certain from the material studied here that there was any marked variation of currents at any particular time because of the geomorphology, although the plateau is deeper on average now than at any time in the past. It could be expected, all other things being equal, that the plateau is less effective now as a barrier to circulation. There is no obvious evidence of winnowing by any current activity nor of any significant development of hiatuses in the sediment column except as noted earlier. 
Table 4. Distribution of benthic species in samples from Holes $750 \mathrm{~A}$ and $750 \mathrm{~B}$.

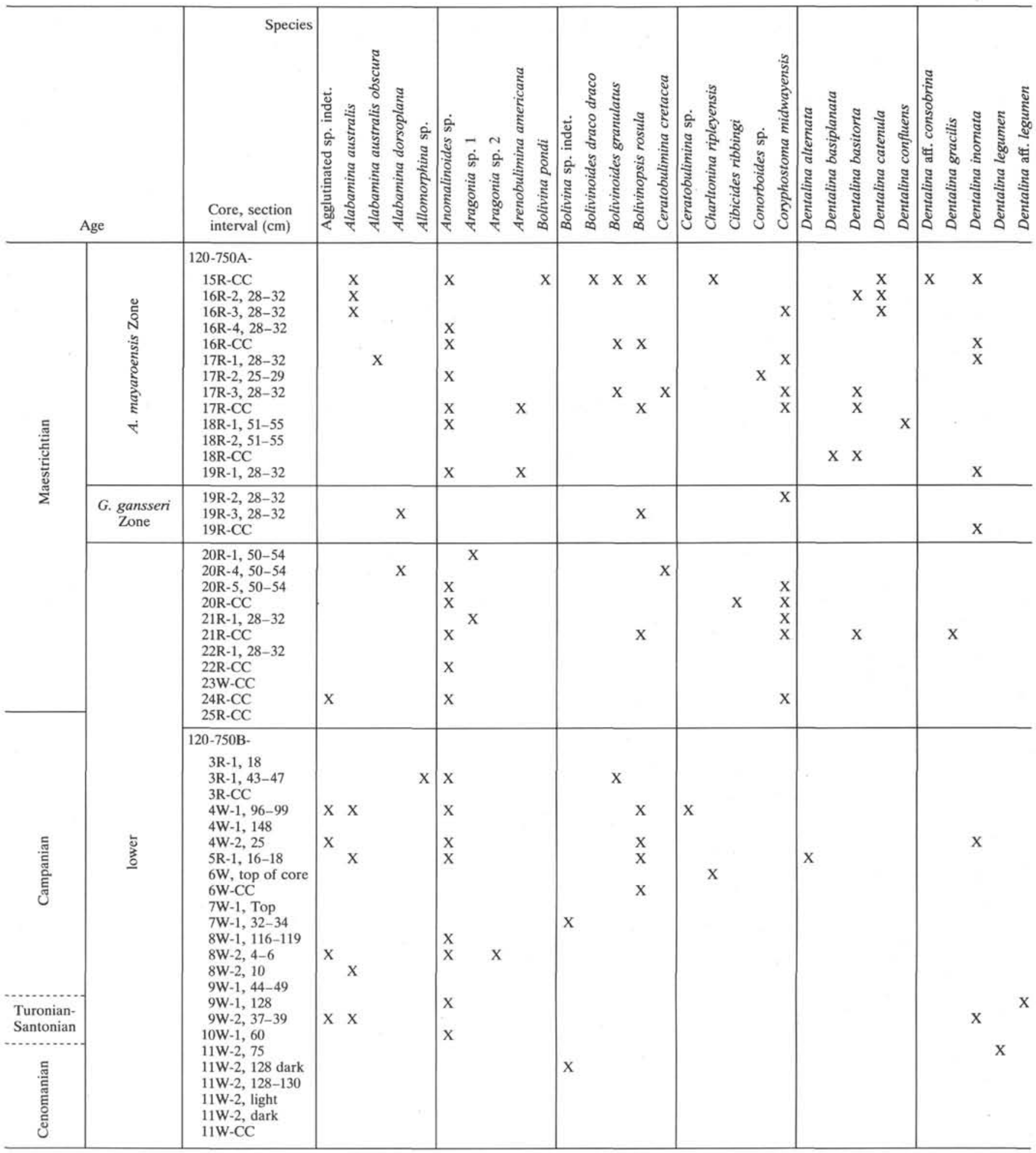

Note: See note to Table 1 for an explanation of the symbols used in the table.

On Kerguelen Plateau itself, from studies conducted as a result of Leg 120 , there is a clear differentiation of environments of deposition at Site 748 from those at Sites 747 and 750; Table 5). The latter were accumulating at bathyal depths whereas at Site 748 , conditions were much shallower. During formation of the earlier part of the se- quence (pre-Campanian), there is ample evidence at Site 748 of nearby vegetated land, probably volcanic islands. The section at the site contains a significant component of terrigenous material, either as slightly modified detritus (such as quartz and clay in gray shale) or as highly modified detritus (now glauconite). Diagenesis has been 


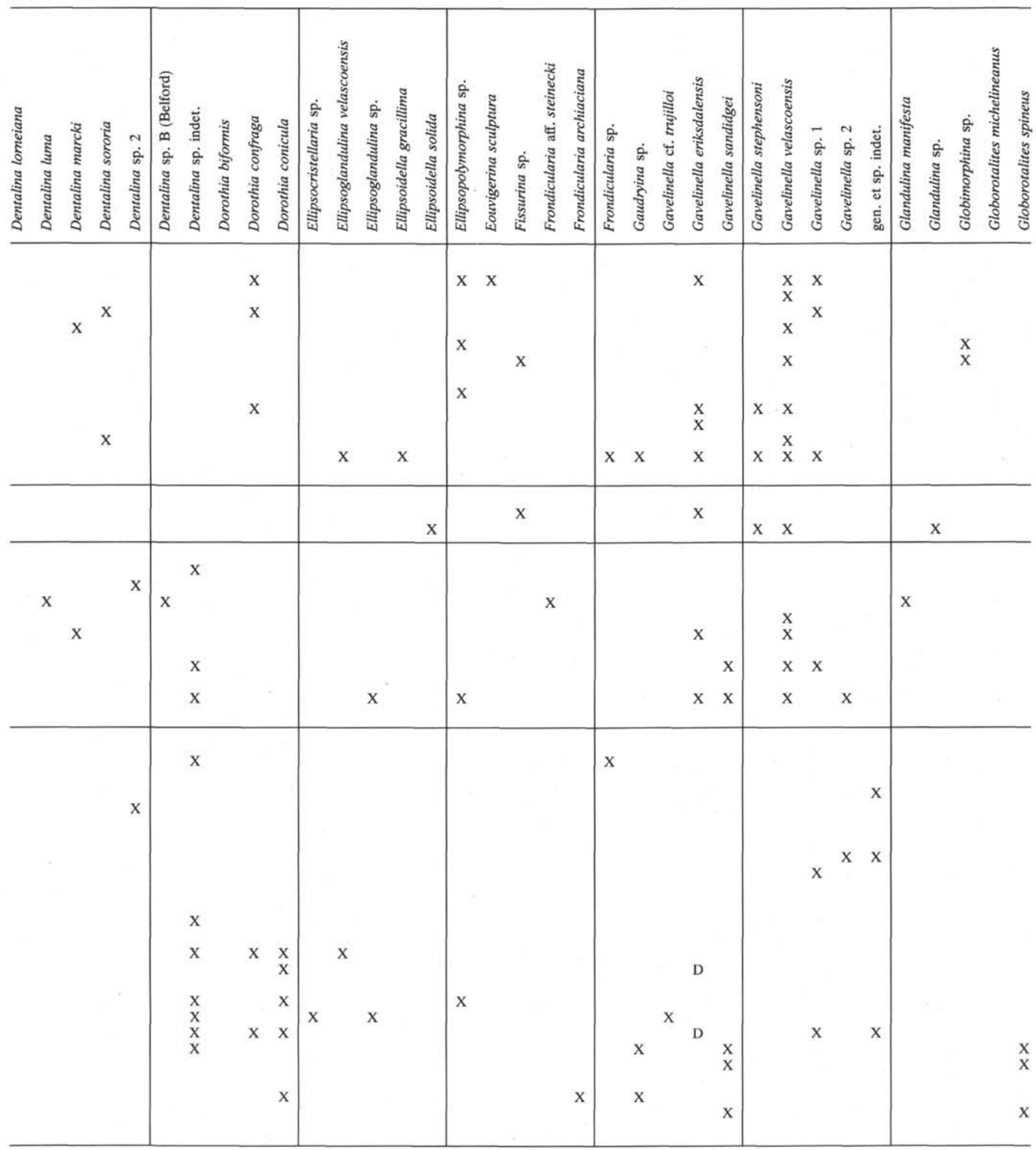

important at Site 748 to a much greater degree than at the other two sites.

Below Core $120-748 \mathrm{C}-61 \mathrm{R}$, the only fossil material (other than siliceous microfossils) obvious in foraminiferal residues is wood (in truth, mainly charcoal) and bone, the latter sporadically making up a significant part of the residue, almost always as unidentifiable fragments but sometimes as teeth and fragments that could be allocated to particular bone types. The most characteristic component of the sediment in this section (the lower part of Subunit IIIB) is glauconite. One sample yielded a doubly terminated quartz crystal. The presence of zeolites below Core $120-748 \mathrm{C}-63 \mathrm{R}$ indicates that there 


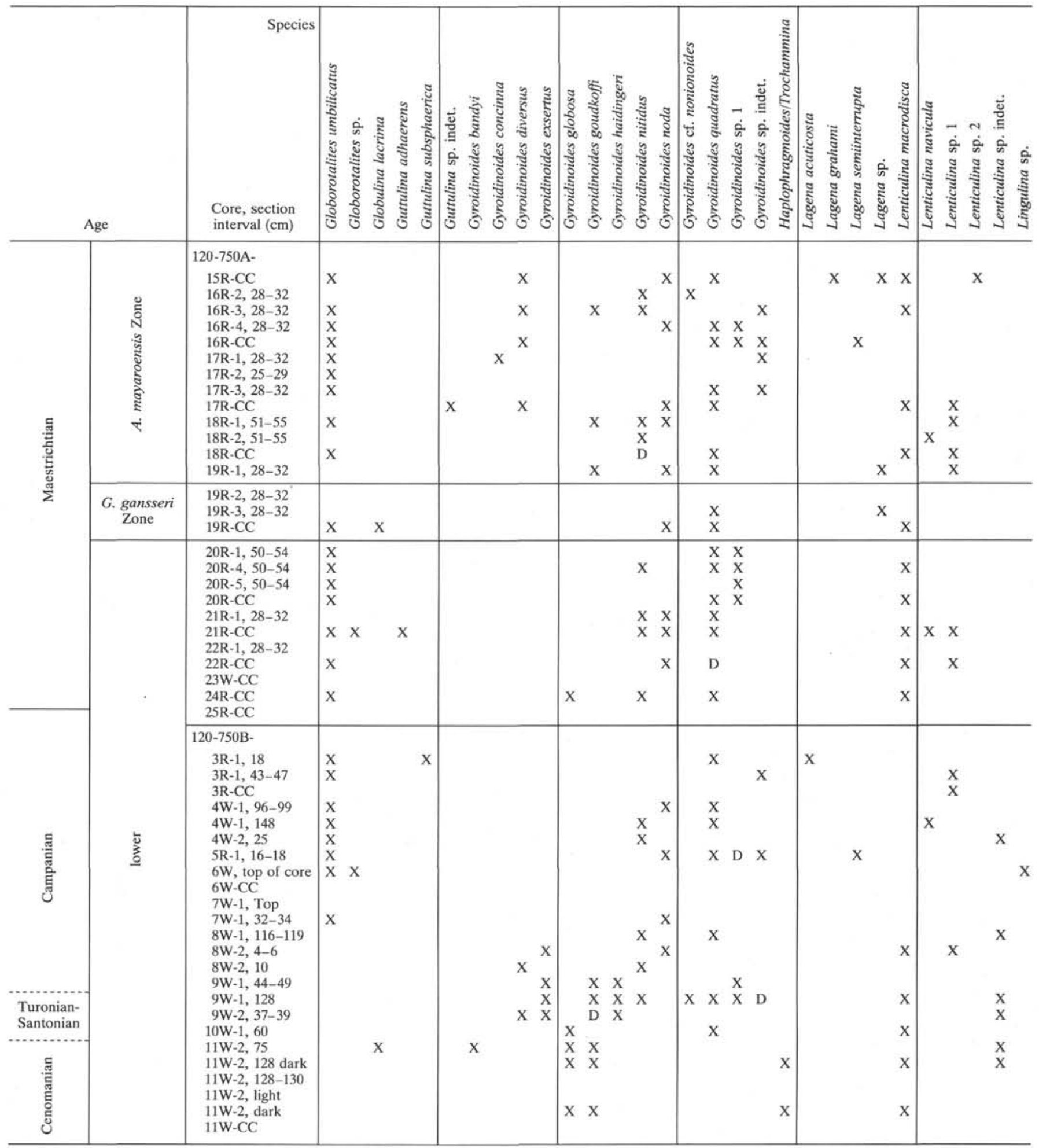

may have been significant volcanism in the vicinity, and this, coupled with the wood fragments lower in the section, is consistent with the concept of vegetated volcanic islands, not necessarily a large emergent landmass.

Subunit IIIB at Site 748 accumulated in a very shallow basin (i.e., the Raggatt Basin). Even the later Cretaceous section is still representative of a shallower environment than existed at the same time at the other two sites. The top of the Cretaceous section at Site 748 is now $\sim 650-700 \mathrm{~m}$ more elevated than that of Site 750 , probably similar to the difference that existed at the time of deposition. Paradoxically, part of the Southern Kerguelen Plateau now represented by Site 748 is the shallowest now and was very shallow throughout the later Cretaceous, but it is located 


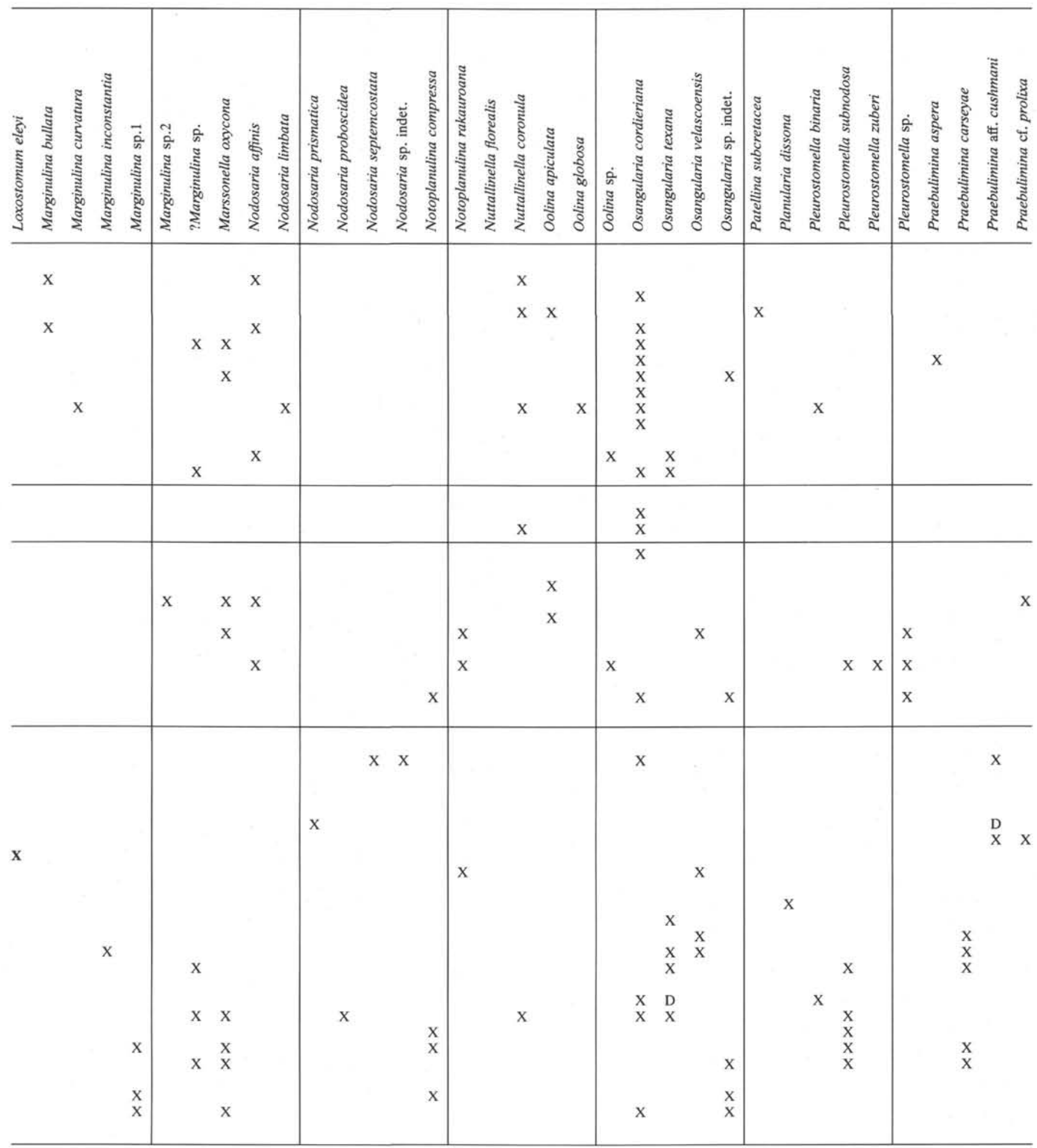

directly over one of two structural depressions, partly through coincidence. The $77^{\circ} \mathrm{E}$ Graben was not drilled by Leg 120. Parts of the plateau may always have been above sea level, as Heard, McDonald, and Kerguelen islands are now.

The abundance of siliceous microfossils (radiolarians, sponge spicules, etc.) in some samples from Hole $748 \mathrm{C}$ is apparently in conflict with the above statement, but the west coast of Australia (nearby at the time) is notable for the common presence of these siliceous elements in shallowwater sediments that are older (late Aptian Windalia Radiolarite and equivalents of the Carnarvon Basin) or approximately coeval (Osborne Formation and equivalents in the Perth Basin-Albian/Cenomanian; see Geological Survey of 


\section{P. G. QUILTY}

Table 4 (continued).

\begin{tabular}{|c|c|c|c|c|c|c|c|c|c|c|c|c|c|c|c|c|c|}
\hline \multicolumn{2}{|c|}{ Age } & $\begin{array}{l}\text { Core, section } \\
\text { interval }(\mathrm{cm})\end{array}$ & 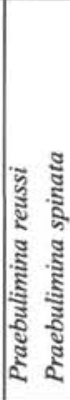 & 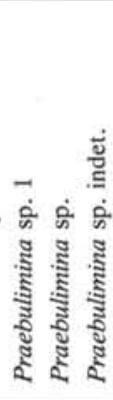 & 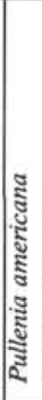 & 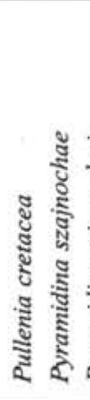 & 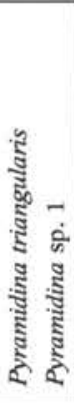 & 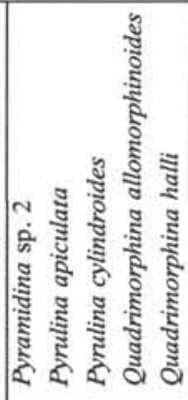 & 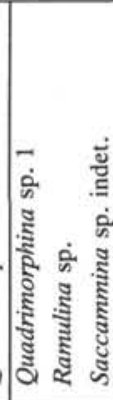 & 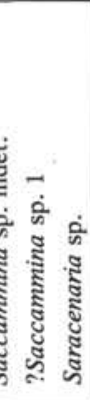 & 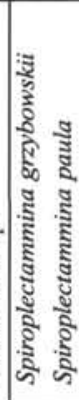 & 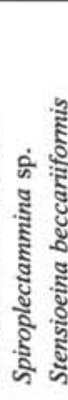 & 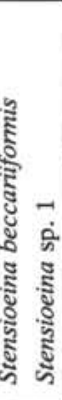 & 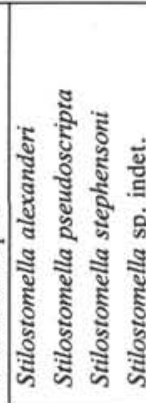 & 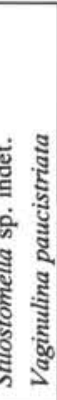 & \multicolumn{2}{|c|}{ 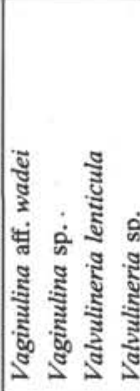 } \\
\hline \multirow{3}{*}{ 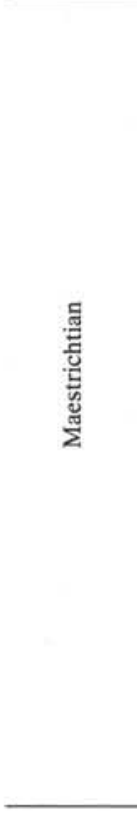 } & 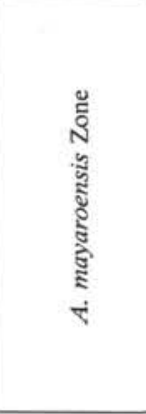 & \begin{tabular}{|l}
$120-750 \mathrm{~A}-$ \\
$15 \mathrm{R}-\mathrm{CC}$ \\
$16 \mathrm{R}-2,28-32$ \\
$16 \mathrm{R}-3,28-32$ \\
$16 \mathrm{R}-4,28-32$ \\
$16 \mathrm{R}-\mathrm{CC}$ \\
$17 \mathrm{R}-1,28-32$ \\
$17 \mathrm{R}-2,25-29$ \\
$17 \mathrm{R}-3,28-32$ \\
$17 \mathrm{R}-\mathrm{CC}$ \\
$18 \mathrm{R}-1,51-55$ \\
$18 \mathrm{R}-2,51-55$ \\
$18 \mathrm{R}-\mathrm{CC}$ \\
$19 \mathrm{R}-1,28-32$
\end{tabular} & $\begin{array}{l}\mathrm{x} \\
\mathrm{x} \\
\mathrm{x} \\
\mathrm{x} \\
\mathrm{D} \\
\\
\mathrm{x} \\
\mathrm{x} \\
\mathrm{D}\end{array}$ & X & $\begin{array}{l}x \\
x \\
x\end{array}$ & $\begin{array}{l}\mathrm{X} \\
\mathrm{X} \\
\mathrm{x} \\
\mathrm{x} \\
\mathrm{x} \\
\mathrm{x} \\
\mathrm{x}\end{array}$ & $\begin{array}{l}\mathrm{X} \\
\mathrm{D} \\
\mathrm{X} \\
\mathrm{X} \\
\mathrm{X} \\
\mathrm{X}\end{array}$ & $x$ & $\begin{array}{l}x \\
x\end{array}$ & $\mathrm{x}$ & $\begin{array}{l}\mathrm{X} \\
\mathrm{X} \\
\mathrm{X} \\
\mathrm{X} \\
\mathrm{D} \\
\mathrm{X} \\
\mathrm{X} \\
\mathrm{X} \\
\mathrm{X} \\
\mathrm{X} \\
\mathrm{D}\end{array}$ & $\begin{array}{l}X \\
X \\
X \\
X \\
D \\
X \\
D \\
X \\
D \\
D \\
D \\
D \\
X \\
D\end{array}$ & $\begin{array}{l}X \\
X \\
X \\
X \\
D \\
D \\
X \\
D \\
X \\
D \\
D \\
D \\
D \\
X \\
D\end{array}$ & 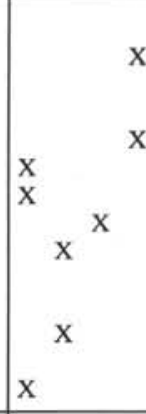 & $X$ & & $\mathrm{X}$ \\
\hline & $\begin{array}{l}\text { G. gansser } \\
\text { Zone }\end{array}$ & $\begin{array}{l}19 \mathrm{R}-2,28-32 \\
19 \mathrm{R}-3,28-32 \\
19 \mathrm{R}-\mathrm{CC}\end{array}$ & $\begin{array}{l}X \\
X \\
\end{array}$ & & & $\mathrm{X}$ & & $\mathrm{x}$ & & & $\begin{array}{l}x \\
x\end{array}$ & $\begin{array}{l}\mathrm{X} \\
\mathrm{D} \\
\mathrm{D} \\
\end{array}$ & & $\mathrm{X}$ & $x$ & & \\
\hline & & $\begin{array}{l}20 \mathrm{R}-1,50-54 \\
20 \mathrm{R}-4,50-54 \\
20 \mathrm{R}-5,50-54 \\
20 \mathrm{R}-\mathrm{CC} \\
21 \mathrm{R}-1,28-32 \\
21 \mathrm{R}-\mathrm{CC} \\
22 \mathrm{R}-1,28-32 \\
22 \mathrm{R}-\mathrm{CC} \\
23 \mathrm{~W}-\mathrm{CC} \\
24 \mathrm{R}-\mathrm{CC} \\
25 \mathrm{R}-\mathrm{CC}\end{array}$ & $\begin{array}{l}\mathrm{X} \\
\mathrm{D} \\
\mathrm{D} \quad \mathrm{X}\end{array}$ & & $x$ & $\begin{array}{l}\mathrm{X} \\
\mathrm{X} \\
\mathrm{x} \\
\mathrm{x}\end{array}$ & $\mathrm{x}$ & ${ }^{X}$ X & & & $\begin{array}{l}x \\
x \\
x \\
x \\
x \\
x \\
12\end{array}$ & $\begin{array}{l}\mathrm{D} \\
\mathrm{D} \\
\mathrm{D} \\
\mathrm{X} \\
\mathrm{D} \\
\mathrm{X} \\
14\end{array}$ & $\begin{array}{l}D \\
D \\
D \\
D \\
D \\
D \\
X \\
14\end{array}$ & $x$ & & & $\mathrm{X}$ \\
\hline
\end{tabular}

Western Australia, 1975; Playford et al., 1976; and Quilty in Logan et al., 1976) with those at Hole 748C.

By the Albian/Cenomanian, the Indian Ocean had evolved, and the main growth was occurring to the north of the combined Broken Ridge-Kerguelen Plateau unit, which was now southeast of the spreading system forming the ocean floor.
The Kerguelen Plateau paleogeography has great significance for the broader regional scene. Sliter (1976) reconstructed Southern Hemisphere paleogeography and attempted to reconstruct the circulation patterns. As he indicated then, and as is still maintained (Royer and Sandwell, 1989), Broken Ridge and Kerguelen Plateau were one unit to the north with Southern Kerguelen Plateau an essentially separate but con- 


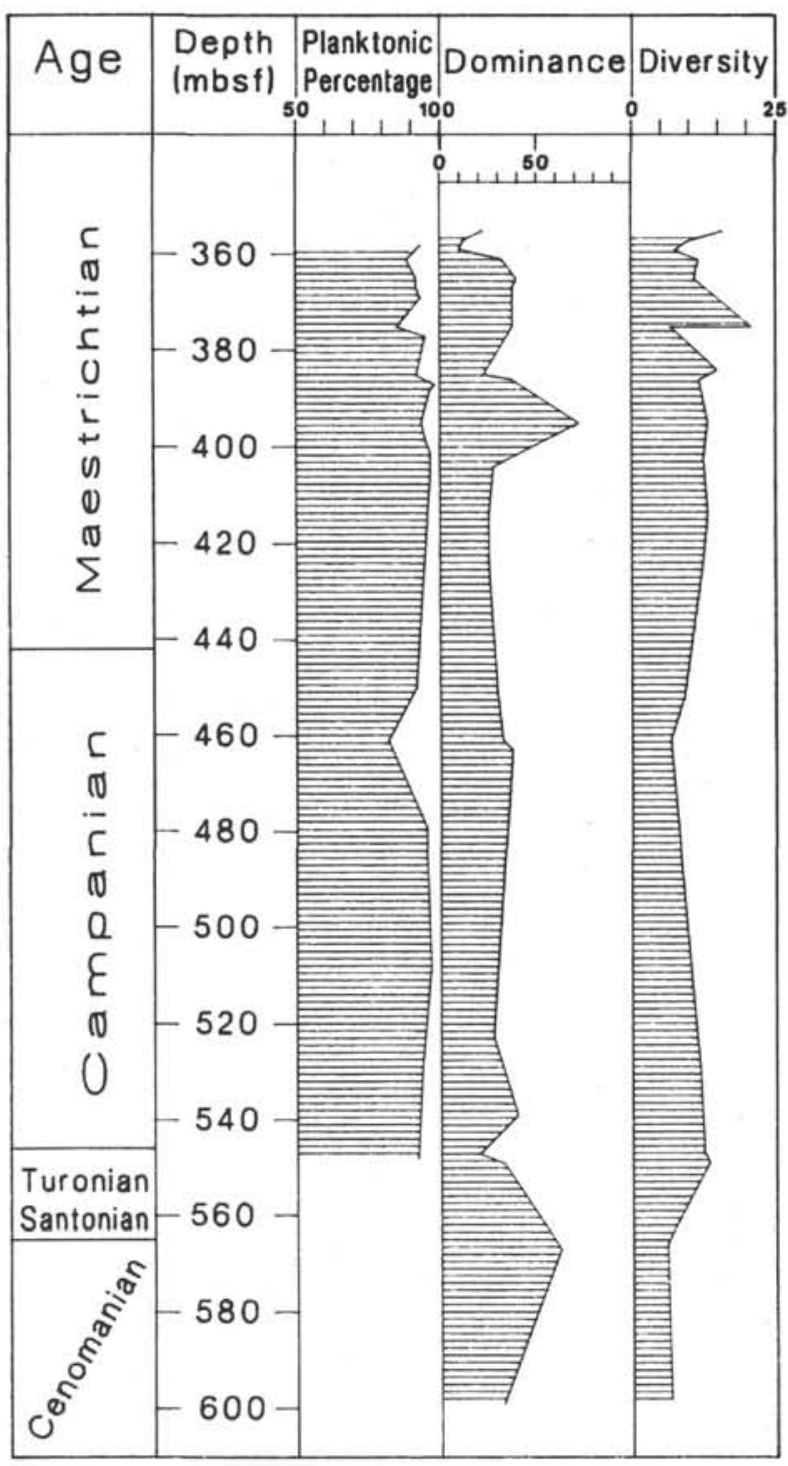

Figure 5. Planktonic percentage, dominance, and diversity results, Cretaceous marine section Site 750 .

tiguous unit, as now. The flow of water over this unit, then much shallower in part, could not have been as postulated by Sliter (1976), and a partition of water into the one passing to the north and the one passing to the south would now be seen as more reasonable. It is to be expected that this would be marked by a series of hiatuses in sedimentary sections especially to the south between Kerguelen Plateau and Antarctica east of Prydz Bay. Drilling is needed in that locality to test this hypothesis.

\section{SYSTEMATIC PALEONTOLOGY}

The order of treatment in this section follows the classification of the Foraminiferida of Loeblich and Tappan (1987). If there are differences of approach, they are noted. Synonymies quoted are not to be taken as comprehensive but only as relevant to the species as they occur here. The original citation for generic names (e.g., d'Orbigny, 1826 ) is not included in the reference list unless referred to in some other context. Full details of such citations are included in Loeblich and Tappan (1987). The year of description of the genus, therefore, does not relate to a specific paper in the references.

Specimens referred to herein are cataloged in the collections of the Australian Commonwealth Paleontological Collection (CPC) curated by the Bureau of Mineral Resources, Geology and Geophysics,
Canberra, and the specimen number quoted in the plate explanations is the accession number in that collection. Specimens have already been lodged with that institution.

\section{Order FORAMINIFERIDA Eichwald, 1830 \\ Superfamily ASTRORHIZACEA Brady, 1881 \\ Family SACCAMMINIDAE Brady, 1884 \\ Genus SACCAMMINA Carpenter, 1869}

Saccammina spp.

(Plate 1, Figs. 2-5)

Remarks. Species of Saccammina occur in the lower part of the sequence in Hole $748 \mathrm{C}$ and at the base of the section in Hole 750B. Those from the former site are referred to sp. 1 and sp. 2 as they are distinct forms with very strong similarity to Saccammina. There are other specimens less clearly differentiated and these are included under the general heading of Saccammina sp. indet. Two "forms" were recognized from Hole $750 \mathrm{~B}$. One is a species, but it is difficult to identify because it has been crushed and thus is not in its original form. This is recorded as Saccammina sp. indet. The other is also somewhat crushed but may originally have been discoid. It has a robust skeleton that seems to be nonagglutinated as well as welldeveloped radial pores through the wall. It may be a radiolarian, but the walls seem too robust and thick, or it could be a sponge. It is recorded as Saccammina(?) sp. 1.

\section{Superfamily SPIROPLECTAMMINACEA Cushman, 1927 Family SPIROPLECTAMMINIDAE Cushman, 1927} Genus BOLIVINOPSIS Yakovlev, 1891

\section{Bolivinopsis rosula (Ehrenberg), 1854}

(Plate 1, Fig. 6)

Spiroplecta rosula Ehrenberg, 1854, p. 32, fig. 26.

Bolivinopsis rosula (Ehrenberg) McFadyen, 1933, p. 141.

Bolivinopsis rosula (Ehrenberg) Cushman, 1946, p. 101, pl. 44, figs. 4-8.

Remarks. Specimens occur sporadically throughout the sections at all three sites and are always a minor component. Some specimens could be placed in either this species or $B$. clotho (Grzybowski), but there is no reason to suspect that more than one species is present. The initial spiral part is rarely preserved. Normally there is little external evidence of the chamber details in the biserial portion, but in some specimens the sutures are depressed on the test margin.

\section{Genus SPIROPLECTAMMINA Cushman, 1927}

\section{Spiroplectammina grzybowskii Frizzell, 1943}

(Plate 1, Fig. 8)

Spiroplectammina grzybowskii Frizzell, 1943, p. 339, pl. 12, figs. 12-13. Spiroplectammina grzybowskii (Frizzell) Belford, 1960, p. 7, pl. 1, figs. 4-6.

Spiroplectammina grzybowskii (Frizzell) McNulty, 1984, p. 558, pl. 1, fig. 6.

Remarks. Some of the forms identified here are large and irregular, similar to those figured by Hornibrook et al. (1989) as Bolivinopsis spectabilis, but most of the specimens referred to $S$. grzybowskii are short and lack the large number of biserial chambers that would be consistent with placing them in synonymy with Bolivinopsis spectabilis, as suggested by Hornibrook et al. (1989). The sides of the test generally taper gently as in the early parts of $B$. spectabilis. To my mind, the question of synonymy is still open.

This is a common component of the agglutinated fraction of many samples. Often it is the only agglutinated form present and usually occurs as fragments. Commonly it has scattered, highly reflective, metallic, black (or more rarely golden) markings or patches on the test surface. These also occur on some other species, regardless of whether or not the species is agglutinated. They may be diagenetic, but as this feature is not general throughout the accompanying fauna but seems to be restricted to a very small number of species, I prefer to think that they are original. If these marks are sulfide (pyrite?), they may reflect that some species, such as this, lived under reducing conditions, perhaps within the sediment.

Included in this species are what appear to be the initial coils of this species. They show no signs of having developed into "adults." Their allocation to $S$. grzybowskii is tentative. 
Table 5. Summary of paleodepth interpretation for Cretaceous sediments in Leg 120 sites.

\begin{tabular}{||c|c|c|c||}
\hline Age & Site 747 & Site 748 & Site 750 \\
\hline Maestrichtian & $\begin{array}{c}\text { lower bathyal } \\
\text { (upper) }\end{array}$ & upper neritic & bathyal \\
\hline Campanian & $\begin{array}{c}\text { middle bathyal } \\
\text { (lower) }\end{array}$ & upper neritic & bathyal \\
\hline Santonian & $\begin{array}{c}\text { middle bathyal } \\
\text { (upper) }\end{array}$ & upper neritic & middle bathyal \\
\hline Coniacian & --- & Salt marsh/estuary & upper bathyal \\
\hline Turonian & $\ldots--$ & Salt marsh/estuary & upper bathyal \\
\hline Cenomanian & --- & --- & neritic \\
\hline Albian & $\ldots---$ & fluvial \\
\hline \hline
\end{tabular}

Spiroplectammina laevis (Roemer), 1841

(Plate 1, Fig. 9)

Textularia laevis Roemer, 1841, p. 97, pl. 15, fig. 17.

Spiroplectammina laevis var. cretosa 1932a, p. 87, pl. 11, figs. 3a-b.

Spiroplectammina laevis var. cretosa Cushman. Belford, 1960, p. 8, pl. 1, figs. 7-10.

Spiroplectammina laevis (Roemer) Sliter, 1968, p. 46, pl. 2, fig. 9.

Remarks. I have followed Sliter's approach in regarding all those forms, originally identified to variety level as $S$. laevis cretosa, as within the range of variation of Roemer's species. It occurs sporadically throughout the sequence in Hole $748 \mathrm{C}$ and is rare in Section 120-747A26X-CC, the only sample from that site in which it is known.

Spiroplectammina paula Belford, 1968

(Plate 1, Fig. 11)

Spiroplectammina paula Belford, 1960, p. 8, pl. 1, figs. 11-13.

Remarks. The specimens found here are never complete and usually consist of the latter part of the test without the initial chambers.

\section{Spiroplectammina sp.}

(Plate 1, Fig. 10)

Remarks. This name is applied generally for unidentified fragments of species of this genus occurring sporadically throughout the section in Holes $748 \mathrm{C}$ and $750 \mathrm{~B}$, but it also includes the form illustrated from Sample $120-748 \mathrm{C}-47 \mathrm{R}-1,124-126 \mathrm{~cm}$. This species has a significant shoulder on the apertural end of all but the last few chambers. It is a robust, compact form.

Superfamily ATAXOPHRAGMIIDEA Schwager, 1877 Family ATAXOPHRAGMIIDAE Schwager, 1877 Genus ARENOBULIMINA Cushman, 1927

Arenobulimina aff. americana Cushman, 1936 (Plate 1, Fig. 13)

Arenobulimina americana Cushman, 1936b, p. 27, pl. 4, figs. 9a-b. Arenobulimina americana (Cushman) Cushman, 1946, p. 42, pl. 12, fig.

1.

Remarks. The single specimen from Sample 120-747A-23X-5, $28-32 \mathrm{~cm}$, is typical of the forms scattered throughout all sections studied in that it seems immature because of its small size and lack of a concave margin; hence, the tentative identification.

\section{Superfamily TEXTULARIACEA Ehrenberg, 1838 \\ Family EGGERELLIDAE Cushman, 1937 \\ Genus MARSSONELLA Cushman, 1933}

Marssonella oxycona (Reuss) 1860

(Plate 1, Fig. 17)

Gaudryina oxycona Reuss, 1860 , p. 229 , pl. 12 , fig. 3 .

Marssonella oxycona (Reuss) Cushman, 1933a, p. 36, pl. 4, figs. $13 \mathrm{a}-\mathrm{b}$.
Marssonella oxycona (Reuss) Belford, 1960, p. 16, pl. 4, figs. 1-3. Gaudryina oxycona (Reuss) Hemleben and Troester, 1984, p. 517, pl. 4, fig. 23.

Remarks. This species is commonly represented by small specimens with a high apical angle. These are taken as juveniles, in agreement with Hemleben and Troester (1984). This form of occurrence as juveniles seems restricted to a few agglutinated species such as this, Arenobulimina americana, and Bolivinopis spectabilis. The significance is unknown.

\section{Superfamily MILIOLACEA Ehrenberg, 1839 Family MILIOLIDAE \\ Genus QUINQUELOCULINA d'Orbigny, 1826}

\section{Quinqueloculina sp.}

Remarks. The single specimen seen is a poorly preserved form akin to $Q$. antiqua angusta Franke as recorded by Cushman (1946). It is one of only two or three miliolids to be recovered from any of the sites drilled on the Kerguelen Plateau, and it is the only one identifiable, even at a generic level, reflecting the absence of a continental shelf depth or environment at any site.

\section{Superfamily NODOSARIACEA Ehrenberg, 1838 Family NODOSARIIDAE Ehrenberg, 1838 Genus DENTALINA Risso, 1826}

Dentalina inornata d'Orbigny, 1846 (Plate 1, Fig. 27)

Dentalina inornata d'Orbigny, 1846, p. 44, pl. 1, figs. 50-51. Dentalina sp. cf. inornata d'Orbigny. Belford, 1960, p. 33, pl. 9, figs. 11-15.

Remarks. This name is applied to the same species identified tentatively by Belford (1960). It may be the same form identified by Sliter (1968) as D. gracilis (d'Orbigny)

\section{Dentalina lorneiana d'Orbigny, 1840 (Plate 1, Fig. 29)}

Dentalina lorneiana d'Orbigny, 1840 , p. 14, pl. 1, figs. 8-9. Dentalina lorneiana (d'Orbigny) Cushman, 1946, p. 66, pl. 23, figs. 7-11.

Remarks. This name is applied to a few specimens consisting of one or two elongate, smooth chambers. Some forms that should be placed in $D$. consobrina d'Orbigny may inadvertently be misplaced here.

\section{Dentalina luma Belford, 1960}

(Plate 1, Fig. 30)

Dentalina luma Belford, 1960 , p. 34, pl. 10, figs. 6-11.

Remarks. This species is separated from $D$. basiplanata Cushman because it has a basal spine; however, in fragments without the base, the differentiation is difficult. In that case, the characters of 
the sutures on the inside of the curved portion may be used when $D$. luma has sutures directed markedly toward the apertural end of the test.

\section{Dentalina marcki Reuss, 1860 \\ (Plate 1, Fig. 31)}

Dentalina marcki Reuss, 1860 , p. 188, pl. 2, fig. 7.

Dentalina marcki (Reuss) Belford, 1960, p. 31, pl. 9, figs. 1-3.

Dentalina marcki (Reuss) Sliter, 1968, p. 58, pl. 5, fig. 19.

Remarks. The material named here is similar in most respects to that recorded by Belford (1960), but it occurs mainly as fragments and thus some of the identifications may be tentative. It differs from the material named by Sliter (1968) in that the ribs are not discrete.

Dentalina sp. A

(Plate 1, Fig. 34)

Dentalina sp. A, Belford, 1960, p. 35, pl. 10, figs. 12-14.

Remarks. This name is as used by Belford (1960).

Dentalina sp. 1

(Plate 1, Fig. 35)

Remarks. This name is used for a few specimens that are characterized by a consistently irregular growth form, including variations in the relative lengths of chambers and degrees of suture depression within one specimen. The figured specimen illustrates these features well.

Dentalina sp. 2

(Plate 1, Fig. 36)

Remarks. This species is akin to $D$. confluens Reuss, as recorded by Cushman (1946). Although still a robust species, it has fewer ribs.

\section{Dentalina sp. indet.}

Remarks. This term is used to include smooth-shelled, broken fragments. If the initial portion is preserved, an attempt was made to allocate it to an identified species.

The specimen from Sample 120-747A-21X-3, 40-42 cm, is not fragmentary, but an unusual growth form consisting of very elongate early chambers with virtually flush oblique sutures and a globular final chamber with depressed sutures perpendicular to the growth axis. It may be related to Dentalina sp. 1 .

\section{Genus NODOSARIA Lamarck, 1812}

\section{Nodosaria aff. affinis Reuss, 1845}

$$
\text { (Plate 1, Fig. 37) }
$$

Nodosaria affinis (Reuss) Cushman, 1946, p. 70, pl. 25, figs. 8-23. Nodosaria sp. cf. affinis (Reuss) Belford, 1960, p. 39, pl. 11, figs. $10-12$.

Nodosaria septemcostata (Geinitz) Sliter, 1968, p. 54, pl. 4, fig. 16.

Remarks. Two types of specimens are included here. One consists of multichambered, multiribbed forms that can be related to specimens figured by Cushman (1946) as Nodosaria affinis Reuss, by Belford (1960) as Nodosaria sp. cf. affinis Reuss, and by Sliter (1968) as Nodosaria septemcostata Geinitz. Sliter placed Cushman's species in synonymy with $N$. septemcostata. Rare specimens are here placed in $N$. septemcostata when the ribs are fewer and thinner and stand higher than in $N$. affinis. Other specimens included are fragments of multiribbed forms that are otherwise unidentifiable.

\section{Nodosaria cf. proboscidea Reuss, 1851}

$$
\text { (Plate 2, Fig. 3) }
$$

Nodosaria proboscidea Reuss, 1851, p. 7, pl. 1, fig. 6 .

Nodosaria proboscidea (Reuss) Cushman, 1946, p. 72, pl. 26, figs. 12-13.

Nodosaria proboscidea (Reuss) Sliter, 1968, p. 55, pl. 4, figs. 12-13.

Remarks. The form recorded here occurs in sediments as young as the Maestrichtian, rather than only Campanian, which Sliter (1968) regards as typical. Belford (1960) identified N. obscura Reuss and $N$. prismatica Reuss from the Santonian-Campanian of Western Australia. N. obscura is as elongate as the form recorded here, but it has a more gently tapered base, blunter apertural end, and fewer continuous ribs. N. prismatica has fewer ribs and a more pointed base.
Nodosaria sp.

(Plate 2, Figs. 5-6)

Remarks. The form recorded here is a striking and very characteristic species with a very variable chamber form and number, although the number is always few. There are a few strong ribs on the first and ultimate chambers. However, what is a strong rib on the early chamber may not be the strong one on the ultimate chamber, even though the ribs may be continuous. Between the strong ribs, there are one or two series of finer ribs. The aperture is on the neck and the strong ribs continue onto the neck.

Genus LINGULINA d'Orbigny, 1826

Lingulina sp. 14

(Plate 2, Fig. 7)

Remarks. This record is of a small, highly compressed, carinate form from the top of Core $120-750 \mathrm{~B}-6 \mathrm{~W}$. The specimen has a broken base, but otherwise it is well preserved. It is smooth and has slightly depressed intercameral sutures that are gently recurved distally and a slitlike aperture. It is akin to L. taylorana Cushman but lacks flanges and the resulting serrated margin. It differs from Lingulina sp. of Sliter (1985) in having fewer chambers and less strongly recurved sutures.

Genus BERTHELINELLA Loeblich and Tappan, 1957

\section{Berthelinella sp.}

(Plate 2, Fig. 15)

Remarks. The form identified here is a true Berthelinella and is very similar in chamber arrangement, apertural characters, and other diagnostic features to the figure of Loeblich and Tappan (1987, pl. 443, fig. 18). This occurrence is unusual as Berthelinella is usually taken as an index for much older sediments, normally Lower Jurassic, although it also occurs in the Rhaetian (e.g., Quilty, in press). The form illustrated by Sliter (1968, pl. 9, figs. 12-13) would not be placed in Berthelinella.

\section{Family VAGINULINIDAE Reuss, 1860 \\ Genus LENTICULINA Lamarck, 1804}

Lenticulina sp. 1

(Plate 2, Fig. 20)

Remarks. This term includes a species with one constant characteristic: a peripheral flange on the distal part of each chamber. This is continuous from one chamber to the next and is transparent, imperforate, and thin, often broken in part.

\section{Lenticulina sp. 2}

(Plate 2, Fig. 21)

Remarks. This very characteristic form is rare. It is marked by a clear steplike suture at the posterior of each chamber, extending from one umbilicus to the other. There are no umbones, as the surface probably was smooth, and the sutures are straight and directed posteriorly and distally.

\section{Genus ASTACOLUS de Montfort, 1808}

Astacolus sp. cf. richteri (Brotzen), 1936

(Plate 2, Fig. 25)

Astacolus sp. cf. richteri (Brotzen) Sliter, 1968, p. 55, pl. 5, figs. 3-4.

Remarks. This name is used in agreement with Sliter (1968).

\section{Genus MARGINULINA d'Orbigny, 1826}

Marginulina cf. decorata (Reuss), 1855

Remarks. A single specimen of a large species. It is poorly preserved and not figured. The portion preserved is from the initial coil and lacks the later rectilinear part.

\section{Marginulina trilobata d'Orbigny, 1840}

$$
\text { (Plate 2, Fig. 31) }
$$

Marginulina trilobata d'Orbigny, 1840, p. 16, pl. 1, figs. 16-17. Marginulina? trilobata d'Orbigny. Cushman, 1946, p. 64, pl. 22, fig. 22.

Remarks. A single poorly preserved specimen, partly decorticated around the initial coil. 
Marginulina sp. 1

(Plate 2, Fig. 32)

Remarks. The specimen figured here may be a juvenile and thus has not been properly identified.

\section{Marginulina $\mathrm{sp.} 2$}

(Plate 3, Fig. 1)

Remarks. The form identified here is very similar to Sliter's (1968) Marginulina sp. cf. curvatura Cushman, but it is clearly different from the original concept so well illustrated by Cushman (1946). The specimen illustrated here may be juvenile.

Genus MARGINULINOPSIS A. Silvestri, 1904

\section{Marginulinopsis sp.}

(Plate 2, Fig. 23)

Remarks. This form is like $M$. striatocarinata (Cushman and Campbell), but the ribs on this form are confined to the first few chambers. The total range of variation within $M$. striatocarinata has not been fully documented, and, when it is, it may show that this form fits within that range.

\section{Genus PLANULARIA Defrance, 1826}

\section{Planularia tricarinella (Reuss), 1863}

(Plate 3, Fig. 3)

Cristellaria tricarinella Reuss, 1863 , p. 68 , pl. 7 , figs. $9 a-b$

Planularia tricarinella (Reuss) Cushman, 1946, p. 57, pl. 20, figs. 2-3.

Remarks. Rare, typical specimens with all characteristic features preserved.

Family LAGENIDAE Reuss, 1862

Genus LAGENA Watker and Jacob, 1798

Remarks. Lagena occurs as one or two specimens in most samples. Little effort was put into rigorous identification, and a variety of the forms encountered is shown on the plates, identified where this was simple and unambiguous. The generic concept is used conservatively and more embracingly than by Loeblich and Tappan (1987) to include under Lagena many of the species and genera discussed by Patterson and Richardson (1987).

\section{Lagena exsculpta Brady, 1879}

(Plate 3, Fig. 9)

Lagena exsculpta Brady, 1879, p. 61.

Lagena exsculpta (Brady) Brady, 1884, p. 467, pl. 58, fig. 1, and pl. 61 , fig. 5 .

Fissurina exsculpta (Brady) Barker, 1961, pl. 58, fig. 1, and pl. 61, fig. 5.

Remarks. The generic name is preferred over alternatives.

Lagena aff. plumigera Brady, 1881

(Plate 3, Fig. 11)

Lagena plumigera (Brady) Cushman, 1946, p. 95, pl. 39, fig. 17.

Remarks. The name is used in the sense used by Cushman (1946) for a form with secondary ribs between the larger flangelike costae. The species originally described by Brady (e.g., Brady, 1884) appears to have no secondary ribs.

\section{Family POLYMORPHINIDAE d'Orbigny, 1839}

\section{Polymorphinid gen. et sp. indet.} (Plate 3, Fig. 33)

Remarks. Rare specimens occur of a smooth, compressed form that is composed dominantly of a biserial portion with gently depressed sutures. It is tentatively placed in the Polymorphinidae.

\section{Genus PYRULINA d'Orbigny, 1839}

Pyrulina aff. apiculata (Marie), 1941

(Plate 3, Fig. 23)

Pyrulina cylindroides (Roemer) var. apiculata Marie, 1941, p. 175, pl. 27, figs. 257-258.

Pyrulina apiculata (Marie) Sliter, 1968, p. 78, pl. 10, fig. 6.
Remarks. The single, well-preserved specimen occurring in Sample $120-747 \mathrm{~A}-21 \mathrm{X}-3,40-42 \mathrm{~cm}$, has a more elongate test than normal for this species and the base has a very well-marked spine. Other occurrences are more usual forms of the species.

Genus RAMULINA T. R. Jones, 1875

Ramulina sp.

(Plate 3, Fig. 25)

Remarks. Specimens assignable to this genus occur sporadically throughout the samples from the Cretaceous. Only rarely are they adequate for specific identification, and then only approximately. Several species appear to be represented. Other than for Ramulina sp. $\mathrm{B}$ recorded below, any allocation to a species is very tentative.

\section{Ramulina sp. B}

Ramulina sp. B, Belford, 1960, p. 57, pl. 15, fig. 3.

Remarks. Rare specimens are attributable to Belford's unnamed species.

Family GLANDULINIDAE Reuss, 1860

Genus DAINITA Loeblich and Tappan, 1964

Dainita sp.

(Plate 3, Fig. 31)

Remarks. The name is applied very tentatively to a form that has most of the generic criteria; however, the initial chamber details are not clear other than that the arrangement is approximately polymorphinid. The most obvious feature is that marking the position of the entosolenian tube.

\section{Superfamily CONORBOIDACEA Thalmann, 1952 \\ Family CONORBOIDIDAE Thalmann, 1952 Genus CONORBOIDES Hofker, 1952}

Conorboides sp.

(Plate 4, Figs. 1-2)

Remarks. This species is similar in general appearance and chamber details to Conorboides umiatensis (Tappan) described from the Albian of Alaska, and probably is very closely related. This genus previously was recorded from Lower Cretaceous sediments in the Southern Hemisphere by Basov and Krasheninnikov (1983), but this appears to be the first record of the genus from sediments as young as the Upper Cretaceous. The growth form of this species and $C$. umiatensis are identical. The apertural tooth is perhaps better developed in the specimens reported here.

Conorboides is said to be aragonitic; although that has not been determined for these specimens, it is unlikely that they are aragonite because other fossils (such as some fish otoliths that are aragonitic) are absent from all sections. The dorsal or spiral surface is said to be smooth with "somewhat limbate sutures" in $C$. umiatensis, whereas in the specimens from Leg 120 there is a slight roughness, which could be a result of recrystallization, and the sutures are simple and broadly, shallowly depressed. The test outline is circular in contrast with $C$. umiatensis, in which it somewhat lobulate.

The material recorded as a few specimens in each of samples from Sections 120-747C-26X-CC, 120-750A-20R-CC, and 120-748C$46 \mathrm{R}-\mathrm{CC}$ to $-48 \mathrm{R}-\mathrm{CC}$, is consistently upper Campanian in age based on planktonic foraminifers (Sites 747 and 750) (see Quilty, this volume) or calcareous nannofossils (Shipboard Scientific Party, 1989, Site 748). This is consistently younger than the age range so far described for the genus and, combined with the features outlined above, suggests that this is a new species.

\section{Superfamily BOLIVINACEA Glaessner, 1937 Family BOLIVINIDAE Glaessner, 1937 \\ Bolivina aff. pondi Cushman, 1931 (Plate 4, Fig. 3)}

Bolivina pondi Cushman, 1931b, p. 50, pl. 8, figs. 5a-b.

Remarks. Single specimens referred to this species were recovered from two samples in Hole 747C. The identification is based on the change to increased chamber height after an initial phase in which chambers are low. 
Family BOLIVINOIDIDAE Loeblich and Tappan, 1984 Genus BOLIVINOIDES Cushman, 1927

Remarks. Bolivinoides is well represented in the Cretaceous of Leg 120 and many species are present, usually well preserved but in small numbers.

Bolivinoides laevigatus (Marie), 1941

(Plate 4, Fig. 9)

Bolivinoides decorata (Jones) laevigata Marie, 1941, p. 189, pl. 29, fig. 281.

Bolivinoides laevigatus (Marie) Sliter, 1976, pl. 12, fig. 8.

Remarks. This is a rare species, occurring only in Hole $748 \mathrm{C}$ in the upper Maestrichtian. It is small and the ornament is unusual because, in addition to few normal digitate projections across sutures, other elevated areas have a fine network of raised ridges of a form typical of Aragonia. The species has a low apical angle. There is only one digitate projection on each side of the midline. The species seems akin to $B$. sirticus Barr but more delicately ornamented.

Superfamily LOXOSTOMATACEA Loeblich and Tappan, 1962

Family LOXOSTOMATIDAE Loeblich and Tappan, 1962 Genus ARAGONIA Finlay, 1939

Remarks. Loeblich and Tappan (1987) take this genus to be restricted to the lower Tertiary. Two species occur in the Cretaceous of the Kerguelen Plateau and one (Aragonia sp. 1, Plate 4, Fig. 10) is useful as an aid to paleoenvironmental interpretation. For this paper, the Cretaceous forms are included in Aragonia, as was done by van Morkhoven et al. (1986). The only variation needed to the generic diagnosis as provided by Loeblich and Tappan (1987) is to allow the development of more irregular ornamentation on the central part of the sutures.

Aragonia sp. 1

(Plate 4, Fig. 10)

Aragonia sp. 1, van Morkhoven et al., 1986, p. 374, pl. 122, figs. 1-3.

Remarks. This very distinctive species was recorded by van Morkhoven et al. (1986) as a characteristic form from lower bathyal and abyssal depths in Upper Cretaceous and Paleocene faunas. Loeblich and Tappan (1987) restricted the range of forms to be included in Aragonia, leading to the exclusion of this form. It is a rare but consistently present species in the upper parts of the Cretaceous sequence at Site 747 and is taken as having paleobathymetric significance.

\section{Aragonia sp. 2}

(Plate 4, Fig. 11)

Remarks. This form occurs sporadically in the shallow-water sequence at Site 748. It is distinguished from Aragonia sp. 1 in that it has a less angular periphery; a regular, gently tapering form rather than the marked variation in the lateral prolongation of the chambers of $A$. sp. 1; and simple elevated sutures that are confined to a narrow central zone. If it was not for this zone of elevated sutures, the species would be placed in Bolivina.

\section{Genus LOXOSTOMUM Ehrenberg, 1854}

\section{Loxostomum sp. 1}

(Plate 4, Fig. 13)

Pleurostomella nitida (Morrow) Hemleben and Troester, 1984, p. 521 , pl. 6 , fig. 6 .

Remarks. This name is applied to rare specimens that are very much like $L$. minutissimum (Cushman), with chambers that rapidly become elongate after the initial ones. Apertural details are not clear. It also has some characteristics in common with L. gemma (Cushman), as figured by Mello (1969), but the form recorded here is more compressed.

Hemleben and Troester (1984) referred this species to Pleurostomella nitida Morrow, but the proper concept of that species seems to be less compressed than the form found here or recorded by Hemleben and Troester. The degree of compression precludes it being incorporated in Pleurostomella, as that genus is envisaged by Loeblich and Tappan (1987).
Loxostomum sp. 2

(Plate 4, Fig. 14)

Remarks. Apertural details are not well preserved, but the general test form is like that of $L$. plaitum (Carsey). The growth habit is not as regular as that of $L$. plaitum, which Sliter (1968) referred to Coryphostoma.

\section{Superfamily EOUVIGERINACEA Cushman, 1927 \\ Family EOUVIGERINIDAE Cushman, 1927 \\ Genus EOUVIGERINA Cushman, 1926}

Eouvigerina sculptura McNeil and Caldwell, 1981

(Plate 4, Fig. 15)

Eouvigerina aculeata Cushman, 1933b, p. 62, pl. 7, figs. 8a-b.

Eouvigerina sculptura $\mathrm{McNeil}$ and Caldwell, 1981, p. 231, pl. 18, figs. 20-21.

Remarks. This is widespread but never abundant. Within the range of variation, there are forms that approximate $E$. americana Cushman with the rapid increase of chamber height in the last few chambers. These forms are rare, and most are consistent with the concept of $E$. sculptura introduced by McNeil and Caldwell (1981).

Superfamily TURRILINACEA Cushman, 1927

Family TURRILINIDAE Cushman, 1927

Genus PRAEBULIMINA Hofker, 1953

Remarks. This genus is present in many samples but is seldom abundant, although rarely dominant. It is present as a wide diversity of species, mostly difficult to identify. This is a group requiring revision.

\section{Praebulimina plana (Cushman and Parker), 1936}

(Plate 4, Fig. 20)

Buliminella carseyae var. plana Cushman and Parker, 1936, p. 8, pl. 2, figs. 7a-c.

Buliminella carseyae var. plana (Cushman and Parker) Cushman, 1946 , p. 120 , pl. 50 , figs. 16 and 21-22.

Remarks. Common in lowermost Maestrichtian and uppermost Campanian is a well-preserved form that does not fit well into any defined genus, but seems appropriately placed in this family. The species is high spired with chambers increasing rapidly in size, and elongate parallel to the axis of coiling. Sutures are flush. The form of coiling is identical with that of many species of Praebulimina. The feature rendering it distinctive is the aperture, which is a long, low arch parallel to the base of the chamber. It appears to be within the apertural face, bordered above by a thin rim and below by a narrow rim or ridge of the apertural face. There is a thin piece of the apertural face of the ultimate chamber in contact with the previous whorl and separating the aperture from that whorl. This appears to represent a new genus.

\section{Praebulimina aff. prolixa (Cushman and Parker), 1935}

\section{(Plate 4, Fig 21)}

Remarks. A few poorly or incompletely preserved specimens are included here. They differ from $P$. prolix $a$ sensu stricto in being larger and having a single basal spine. They have a torsion throughout growth. The generic assignment is questionable. The species does not have well-developed triangular faces, which would be consistent with Pyramidina in which $P$. prolixa is sometimes placed (e.g., Sliter, 1968).

\section{Praebulimina reussi (Morrow), 1934}

(Plate 4, Fig. 22)

Bulimina ovulum Reuss, 1845, p. 37, pl. 8, figs. 57a-b, and pl. 13, figs. 73a-b.

Bulimina reussi Morrow, 1934, p. 195, pl. 29, fig. 12.

Bulimina ovulum Reuss var. ovulum (Reuss) Frizzel, 1954, p. 115, pl. 17, fig. 2.

Praebulimina ovulum (Reuss) Belford, 1960, p. 64, pl. 16, figs. 7-9. Praebulimina reussi (Morrow) Sliter, 1968, p. 85, pl. 12, figs. 1-2.

Praebulimina reussi (Morrow) McNeil and Caldwell, 1981, p. 225, pl. 18, fig. 12.

Remarks. Despite attempts to remove it, there is still considerable confusion over the correct nomenclature of this species. Belford 
(1960) reviewed the situation in detail and concluded that the name $P$. ovulum Reuss is still available and its use more correct by ICZN rules, following Frizzel's (1954) similar conclusion. McNeil and Caldwell (1981), using almost identical wording, accepted $P$. reussi and pointed out that most authors accepted or used $P$. reussi. Usage and the need for better communication cause me to use $P$. reussi, although I think that $P$. ovulum is more in line with the rules of the ICZN. $P$. reussi is an important species in this study, as it is dominant in many samples.

\section{Praebulimina sp. \\ (Plate 4, Fig. 23)}

Remarks. This species is represented by a single specimen. It is very similar to $P$. cushmani (Sandidge) with one clear difference. At the suture opposite the aperture, each champer has a marked indentation. When a new chamber is added, this indentation remains visible, giving the chambers a very distinctive appearance atypical of species of this genus. Another feature is that sutures are quite depressed, making the chamber arrangement very clear. Although the features of the sutures are similar to those described for $P$. incisa (Cushman), the species are easily differentiated on the basis of suture depression.

\section{Praebulimina sp. 2 \\ (Plate 4, Fig. 24)}

Remarks. This form is very like $P$. spinata (Cushman and Campbell), but it lacks the clear differentiation of the ridge on the apical end of each chamber. The surface, instead of being smooth, has a very fine pustulose pattern, with some of the pustules weakly aligned to form pseudoridges.

\section{Genus PYRAMIDINA Brotzen 1948}

\section{Pyramidina sp. 2}

(Plate 4, Fig. 32)

Remarks. This is identical in growth form to $P$. triangularis (Cushman and Parker) but with very pustulose edges to the triserial test. Test faces between corners are smooth and the chambers indistinct. The Pyramidina sp. of McNeil and Caldwell (1981, pl. 18, figs. 14a-b) is another very similar species in the general features, but it lacks the characteristic pustulose corners of the species recorded here.

\section{Pyramidina sp. 3}

(Plate 5, Fig. 1)

Remarks. Occurring sporadically throughout Hole 747A are specimens of a species of Pyramidina characterized by a regular test shape, about 1.5-2 times as long as wide, with rounded corners, no torsion during growth, and a smooth final chamber. The early part of the test is ornamented variously from a few short spines to dentate projections directed basally to the test edge, occasionally only roughened. The chamber margin is usually marked, except on the final chamber, by a ridge at the line of maximum inflation.

This species is very similar in shape to $P$. szajnochae, but it does not occur with it nor does it appear to intergrade even though the type of ornament is similar.

\section{Genus RECTOBOLIVINA Cushman 1927}

\section{Rectobolivina sp.}

(Plate 5, Fig. 2)

Remarks. A single specimen from a sample of Section 120-748C $50 \mathrm{R}-\mathrm{CC}$ is tentatively placed here. It is poorly preserved, but the broken test wall in the biserial portion allows the toothplate to be emphasized by some overgrowth.

Superfamily PLEUROSTOMELLACEA Reuss, 1860 Family PLEUROSTOMELLIDAE Reuss, 1860 Genus ELLIPSOPOL YMORPHINA A. Silvestri, 1901

\section{Ellipsopolymorphina sp.}

(Plate 5, Figs. 9-10)

Ellipsopolymorphina sp., Sliter, 1968, p. 111, pl. 19, figs. 7-8.

Remarks. The name is used in the same way and for the same form as it has been used by Sliter (1968).

\section{Genus PLEUROSTOMELLA Reuss, 1860}

\section{Pleurostomella zuberi Grzybowski, 1896}

(Plate 5, Fig. 13)

Pleurostomella zuberi Grzybowski, 1896, p. 291, pl. 9, figs. 32-33. Pleurostomella zuberi (Grzybowski) Sliter, 1985, pl. 8, fig. 15.

Remarks. This rarely recorded species occurs as a single specimen in the sample from Section 120-750A-22R-CC.

\author{
Superfamily STILOSTOMELLACEA Finlay, 1947 \\ Family STILOSTOMELLIDAE Finlay, 1947 \\ Genus STILOSTOMELLA Guppy, 1894
}

\section{Stilostomella pseudoscripta (Cushman) 1937a}

(Plate 5, Fig. 15)

Ellipsonodosaria pseudoscripta Cushman, 1937b, p. 103, pl. 15, fig. 14.

Ellipsonodosaria pseudoscripta (Cushman) Cushman, 1946, p. 135, pl. 56, fig. 9.

Stilostomella pseudoscripta (Cushman) Sliter, 1968, p. 90, pl. 13, figs. 6-7.

Remarks. The specimen from Sample 120-747A-21X-2, 60-62 cm, is identical with that figured by Sliter (1968, fig. 6) in that it shows no evidence of striations. The chambers are less distinct than in Sliter's figures. By contrast, other specimens from many samples are more like the original figure of Cushman (1946).

\section{Superfamily DISCORBACEA Ehrenberg, 1838}

Family BAGGINIDAE Cushman, 1927

Genus VALVULINERIA Cushman, 1926

\section{Valvulineria lenticula (Reuss) 1845}

(Plate 5, Figs. 17-18)

Rotalina lenticula Reuss, 1845 , p. 35 , pl. 12 , figs. $17 \mathrm{a}-\mathrm{c}$.

Valvulineria lenticula (Reuss) Belford, 1960 , p. 75 , pl. 20, figs. 3-10 Valvulineria lenticula (Reuss). McNeil and Caldwell, 1981, p. 233, pl. 18 , figs. 23a-c.

Remarks. The few specimens recorded here are generally identical with the usual concept of this species as employed in the literature. McNeil and Caldwell (1981) provided a long synonymy cementing the concept.

Valvulineria sp.

(Plate 5, Fig. 19)

Remarks. The single specimen is very similar to what Sliter (1968) described as Quadrimorphina spirata, but it is less high spired and has a more regular smooth dorsal surface. The umbilical tooth is typical of what has usually been regarded as a characteristic of Valvulineria.

\section{Superfamily PLANORBULINACEA Schwager, 1877 Family CIBICIDIDAE Cushman, 1927 \\ Genus CIBICIDES de Montfort, 1808}

Remarks. The generic name Cibicides is retained for forms that show evidence of an attached life style, as indicated by a flat or undulating spiral surface, perhaps a response to the substrate, and an involute domed surface. The aperture is astride the margin and extends onto both sides of the test. The term is used in the same sense as for Tertiary species, although the usage is in conflict with the suggested time range for the genus given by Loeblich and Tappan (1987). The genus is rare at best in the Cretaceous sections studied.

\section{Cibicides beaumontianus (d'Orbigny), 1840} (Plate 5, Fig. 20)

Truncatulina beaumontina d'Orbigny, 1840 , p. 35, pl. 3, figs. 17-19. Cibicides beaumontianus (d'Orbigny) Cushman, 1946, p. 161, pl. 65, figs. 12a-c.

Falsocibicides beaumontianus (d'Orbigny) Sliter, 1968, p. 109, pl. 19 , fig. 5 .

Remarks. The form identified here seems to be the same as that discussed by Cushman (1946), that is a species with an almost regular growth form. This is in marked contrast with the concept employed by Sliter (1968), which is quite irregular in growth form. 
Cibicides ribbingi Brotzen, 1936

(Plate 5, Figs. 21-23)

Cibicides ribbingi Brotzen, 1936, p. 186, pl. 13, figs. 5a-6c.

Cibicides ribbingi (Brotzen) Belford, 1961, p. 111, pl. 34, figs. 17-20.

Cibicides ribbingi (Brotzen) Sliter, 1985, p. 340, pl. 8, figs. 1-5.

Remarks. Most specimens in the area are typical of the concept normally applied. There are, however, rare specimens that have a less regular growth form and that adopt a sprawling, irregular mode very similar to the one included in specimens figured by Sliter (1985, especially figs. 4 and 5).

Cibicides sp.

(Plate 5, Figs. 24-25)

Remarks. The few specimens recovered from Sample 121-747A23X-CC appear to be genuine Cibicides. They have a concave spiral surface that appears to have been attached in life. The other surface is smooth and evolute with a central well-developed umbo. The small aperture is over the carinate periphery and extends onto both sides of the test. The closest form seems to be $C$. beaumontianus, but the final chambers increase in chamber height at a lower rate and the sutures on the dorsal surface are indistinct.

\section{Superfamily ASTERIGERINACEA d'Orbigny, 1839}

Family EPISTOMARIIDAE Hofker, 1954

Genus NUTTALLINELLA Belford 1959

Nuttallinella florealis (White), 1928

(Plate 5, Figs. 26-27)

Gyroidina florealis White, 1928, p. 293, pl. 41, figs. 3a-c.

Nuttallinella florealis (White) Basov and Krasheninnikov, 1983, p.

765 , pl. 9, fig. 9, and pl. 10, fig. 1.

Nuttallinella florealis (White) van Morkhoven et al., 1986, p. 356, pl. 115 , figs. $1-3$.

Remarks. This distinctive species is rare and occurs only in Core $120-750 \mathrm{~B}-6 \mathrm{~W}$, where it is taken as an index of increasing water depth with time. The specimens do not have well-developed lobes on the umbilical boss, but they are weakly present and the characteristics of the ultimate chamber are the same.

\section{Superfamily NONIONACEA Schultze, 1854}

Family NONIONIDAE Schultze, 1854

Genus PULLENIA Parker and Jones, 1862

\section{Pullenia cretacea Cushman, 1936}

(Plate 5, Fig. 31)

Pullenia cretacea Cushman, 1936a, p. 75 , pl. 13, fig. 8 .

Pullenia cretacea (Cushman) Belford, 1960, p. 88, pl. 24, figs. 13-15. Pullenia cretacea (Cushman) Sliter, 1968, p. 115, pl. 23, fig. 2.

Remarks. This is a common but never abundant form throughout the Cretaceous on the Kerguelen Plateau.

\section{Superfamily CHILOSTOMELLACEA Brady, 1881 Family QUADRIMORPHINIDAE Saidova, 1981 Genus QUADRIMORPHINA Finlay, 1939}

Quadrimorphina halli (Jennings), 1936

(Plate 5, Fig. 32)

Allomorphina halli Jennings, 1936, p. 34 , pl. 4, fig. 5 .

Quadrimorphina halli (Jennings) Troelsen, 1954, p. 469.

Allomorphina halli (Jennings) Sliter, 1968, p. 113, pl. 21, fig. 8.

?Allomorphina whangaia (Finlay) Hornibrook et al., 1989, p. 48, fig. 11 , nos. 13a-b.

Remarks. Like Troelsen (1954), I prefer to place this species in Quadrimorphina because the dorsal surface is distinctly evolute. The evidence used by others for generic assignment (e.g., Loeblich and Tappan, 1987), based on the presence or absence of a toothplate, is not available from the samples seen here.

There seems a high probability that this form is conspecific with Allomorphina whangaia Finlay, originally described from New Zealand and well illustrated by Hornibrook and others (1989). A few forms included here may more properly be referred to Allomorphina minuta Cushman.
Quadrimorphina spirata Sliter, 1968

Quadrimorphina spirata Sliter, 1968, p. 114, pl. 20, fig. 10.

Remarks. This form is represented by only two specimens and preservation is too poor to warrant useful illustration. The identification is based purely on light microscopic examination.

\section{Quadrimorphina sp.}

(Plate 6, Fig. 2)

Remarks. A few specimens are recorded here. The species does not have the well-developed lip characteristic of this genus but seems closely related. The most similar form described appears to be "Discorbis" quadrilobus Mello from the Albian of Canada, which has only four chambers in the final whorl, whereas this form has five. The two species are congeneric, perhaps early in the evolution of Quadrimorphina. This may be the form referred by Scheibnerova (1978) to ?Discorbis $\mathrm{sp}$.

\section{Family ALABAMINIDAE Hofker, 1951 Genus ALABAMINA Toulmin, 1941}

\section{Alabamina australis (Belford) 1960}

$$
\text { (Plate 6, Figs. 22-24) }
$$

Alabamina australis australis Belford, 1960, p. 84, pl. 23, figs. 13-20. Alabamina australis obscura Belford, 1960 , p. 86, pl. 24, figs. 1-8. Alabamina australis australis (Belford) McNeil and Caldwell, 1981, p. 274, pl. 22, figs. 14a-c.

Remarks. I have used Belford's species in the broad sense to include in it the two subspecies australis and obscura. Although $A$. australis australis is very dominant, A. australis obscura does occur, but rarely.

Although the species is rare throughout sections at Sites 747 and 750 , it is an abundant, and even dominant, form in many samples from Site 748 , suggesting a preference for the shallower waters inferred for that section.

It is possible that this species is synonymous with $A$. creta Finlay from contemporaneous sediments of New Zealand.

\section{Family GLOBOROTALITIDAE Loeblich and Tappan, 1984} Genus GLOBOROTALITES Brotzen, 1942

Globorotalites spineus (Cushman), 1926

$$
\text { (Plate 6, Figs. 5-6) }
$$

Truncatulina spinea Cushman, 1926a, p. 22, pl. 2, fig. 10.

Globorotalites spinea (Cushman) McGugan, 1964, p. 949, pl. 152, fig. 13.

Globorotalites spineus (Cushman) Sliter, 1968, p. 119, pl. 22, fig. 4. Globorotalites spineus (Cushman) Basov and Krasheninnikov, 1983, p. 764 , pl. 9 , fig. 1.

Remarks. Typical specimens occur in Core 120-750B-11W, and it seems a likely ancestor for Gyroidinoides quadratus (Cushman and Church), which is a persistent member of most faunas at that site. It is possible that some poorly preserved $G$. spineus have been included in Gyroidinoides quadratus.

\section{Globorotalites umbilicata Loetterle, 1937}

(Plate 6, Figs. 7-8)

Globorotalia umbilicata Loetterle, 1937 p. 43, pl. 6, figs. 9a-c. Globorotalia umbilicata (Loetterle) Cushman, 1946, p. 153, pl. 63, fig. 1.

Globorotalites umbilicatus (Loetterle) Belford, 1960, p. 101, pl. 30, figs. 14-17.

Remarks. This form is a consistent but minor element of uppermost Campanian and Maestrichtian samples. Preservation is good but minor diagenesis does obscure some features in some specimens.

It is small and biconvex, generally with the spiral surface flatter than the ventral. The periphery is sharply angled and slightly but clearly and consistently lobulate in the last few chambers. Dorsal sutures are straight but are directed posteriorly distally and are flush. The central dorsal features are obscured by thickening. It has a ventral surface with a central small umbilicus, apparently not filled with clear shell. 
The fact that the ventral umbilicus is open serves to distinguish this form from those that should be placed in Gemellides Vasilenko (e.g., Gemellides galiciensis [Fisher] Fisher, 1969), to which this form is otherwise very similar.

There is some doubt about the specific identification. It is clearly the form identified by Belford (1960) under this name, but the original illustrations and description refer to a form with a flat dorsal surface. The specimens recorded here uniformly have a low conical dorsal surface.

\section{Family OSANGULARIIDAE Loeblich and Tappan, 1964 Genus OSANGULARIA Brotzen, 1940}

Osangularia cordieriana (d'Orbigny), 1840 (Plate 6, Figs. 11-12)

Rotalina cordieriana d'Orbigny, 1840, p. 33, pl. 3, figs. 9-11. Osangularia cordieriana (d'Orbigny) Sliter, 1968, p. 118, pl. 21, figs. 9a-b.

Osangularia cordieriana (d'Orbigny) Basov and Krasheninnikov, 1983, p. 764 , pl. 9 , figs. $7-8$.

Remarks. The records for Samples 120-747A-23X-6, 28-32 cm, and $-25 \mathrm{X}-3,28-32 \mathrm{~cm}$, are proper identifications of this species. The record from Sample 120-747A-21X-2, 60-62 cm, is taken here as $O$. aff. cordieriana because it has only five chambers in the final whorl and the margin is distinctly lobulate, giving it a quite different appearance.

\section{Osangularia texana (Cushman), 1938}

(Plate 6, Figs. 15-16)

Pulvinulinella texana Cushman, 1938, p. 49, pl. 8, fig. 8 . Pulvinulinella texana Cushman, 1946, p. 143, pl. 59, figs. 8-9.

Remarks. This species is identified positively in only one sample at Site 747 (Sample 120-747C-9R-1, 38-40 cm), but it is more common at Site 750 . It has all the characters of the specimens figured by Cushman, but it is most similar to those with a "ragged" appearance to the flange.

\section{Osangularia sp.}

$$
\text { (Plate 6, Figs. 19-20) }
$$

Remarks. This name is used for an unusual and rare species that occurs in a few samples from Hole 747 A. It is much more robust than is normal for Osangularia in that the flange, instead of being a thin, sharp feature, is quite thick and rounded at its edge.

\section{Genus CHARLTONINA Bermudez, 1952}

Charltonina ripleyensis (Sandidge), 1932

(Plate 6, Figs. 9-10)

Pulvinulinella ripleyensis Sandidge, 1932, p. 315, pl. 29, figs. 7-9.

Pulvinulinella ripleyensis (Sandidge) Cushman, 1946, p. 144, pl. 60, fig. 2.

Remarks. Two specimens were recovered from Sample 120-750A$15 \mathrm{R}-\mathrm{CC}$. Although of the same size and chamber arrangement, there are marked peripheral differences in that one has a well-defined peripheral keel through to the ultimate chamber. The other has such a keel until the beginning of the final whorl, but thereafter the margin is quite rounded. The specimens are quite well preserved but even then apertural details are less than perfectly preserved rendering generic assignment a little tentative.

\section{Family HETEROLEPIDAE González-Donoso, 1969} Genus ANOMALINOIDES Brotzen, 1942

\section{Anomalinoides sp.}

(Plate 6, Fig. 21)

Remarks. Several samples contain one or two specimens of this species, and in two samples there are several specimens. It is robust and equally biconvex; it is involute ventrally and evolute dorsally. The umbilical side has apertural terminations at its center, and the figured specimen shows the extreme development when proximal apertural prolongations or flaps produce a stellar pattern. In most cases, there is not a central feature such as this but a simple deep to shallow groove around the latter half of the umbilical boss. The surface is smooth, with all sutures flush except for the last one, which may be weakly depressed. There are about nine chambers per whorl.

The closest form seems to be $A$. piripaua Finlay, but that species has more chambers (12-13) in the final whorl.

\section{Family GAVELINELLIDAE Hofker, 1956 Genus GYROIDINOIDES Brotzen, 1942}

Remarks. Loeblich and Tappan (1987) have clarified, to a large extent, the generic problems of the allocation of a group of species that can now be assigned to one of the following clearly defined genera: Gyroidina (Holocene), Hansenisca (Oligocene to Holocene), and Gyroidinoides (Upper Cretaceous to Holocene). All have in common a more or less flat dorsal or spiral surface, a thick test with involute ventral surface, an interiomarginal primary aperture, and a flattened apertural face commonly perpendicular to the preceding whorl.

Although the generic allocation is now clearer, the same cannot be said at the species level, certainly for the Upper Cretaceous species, which now are all to be found within Gyroidinoides. During this study, I have found it exceedingly difficult to find the basis for the diagnosis of many of the commonly used species names; thus, I feel that there is a strong need for a reevaluation of the Upper Cretaceous species. A corollary of the problem is that there may be inconsistency in my own allocation of species. Within one sample, one may identify one to several apparently natural groups that would be referred to, in most other genera, as species. With the accompanying fauna being very similar over significant parts of a section, one would conclude that the environment had not changed significantly over considerable intervals and, therefore, that the species of Gyroidinoides should remain roughly constant. The marked variation in names applied over the same interval then suggests that the nomenclature does not reflect the natural variation within the species of the genus and that the apparently natural groupings distinguished are not in fact valid species.

It is not yet clear in the scheme proposed by Loeblich and Tappan (1987) where forms with a conical or domed dorsal (= spiral) surface should be placed. This includes forms that have been placed in the past in Eponides (such as E. diversus Belford) or Gyroidinoides (such as $G$. bandyi [Trujillo] or $G$. goudkoffi [Trujillo]). In this work, the concept of Gyroidinoides is interpreted loosely to allow them to be placed in those categories. In the extreme it includes Gyroidinoides sp. 1, which has an almost flat ventral surface and high domed dorsal surface.

Although discussed separately, there are three species that seem to have a genetic and sequential relationship in the faunas studied here. In holes at Sites 747 and 750, there are indications of evolutionary sequences giving rise to Gyroidinoides quadratus. At Site 750, toward the bottom of the hole, in samples with locations that are poorly controlled, Globorotalites spineus appears to give rise to Gyroidinoides quadratus, but whether or not this is direct or by another form of Gyroidinoides (apparently unnamed) is not clear. I suspect that the unnamed species is simply an aberrant form of $G$. quadratus and that the normal path is direct. In Site 747, at about the same stratigraphic level, there is a possible very different path, by means of Globorotalites umbilicatus through the development of a flange, thickening of the test, and reduction in the number of chambers.

\section{Gyroidinoides concinna (Brotzen), 1936}

(Plate 6, Figs. 29-30)

Eponides concinna Brotzen, 1936, p. 167, pl. 12, figs. 4a-c. Eponides concinna (Brotzen) Belford, 1960, p. 83, pl. 23, figs. 1-6.

Remarks. A common species and one, as noted above, that does not rest easily within the concept of Eponides employed by Loeblich and Tappan (1987).

\section{Gyroidinodes diversus (Belford), 1960} (Plate 6, Figs. 31-32)

Eponides diversus Belford, 1960, p. 82, pl. 22, figs. 16-26.

Remarks. This form is differentiated from $G$. goudkoffi (Trujillo) by its sharper periphery and more clearly demarcated chambers on the dorsal surface. In addition, it has a more highly domed ventral surface than $G$. goudkoffi. No intergradational forms were seen, and thus the species seem distinct. 
Gyroidinoides globosa (Hagenow), 1842

(Plate 7, Figs. 4-5)

Nonionina globosa Hagenow, p. 574.

Gyroidina globosa (Hagenow) Cushman, 1946, p. 140, pl. 58, figs. 6-8. Gyroidina globosa (Hagenow) Belford, 1960, p. 78, pl. 21, figs. 4-9.

Remarks. This species is one in which there is a great deal of variation in concept throughout the literature. It is taken here to include forms with a slightly domed dorsal surface, six to seven chambers in the final whorl, and a test less thick or robust than is used for such species as $G$. nitida or $G$. girardana.

Included are forms that could be referred to $G$. cf. globosa as used by Huber (1988). These are rare and a little in conflict with the comments made above because they are thicker and more robust than specimens I would normally include here.

\section{Gyroidinoides aff. haidingerii (d'Orbigny), 1846} (Plate 7, Figs. 8-9)

?Rotalina haidingerii d'Orbigny, 1846, p. 154, pl. 8, figs. 7-9. Eponides haidingerii (D’Orbigny) Cushman, 1946, p 142, pl. 57, figs. $13 \mathrm{a}-\mathrm{c}$.

Remarks. There is confusion over what constitutes $G$. haidingerii sensu stricto. D'Orbigny described the species from the Miocene of the Vienna Basin; however, the original figures cannot be used with confidence, hence the absence of many figures of the species in the literature.

Parr (1950) discussed the problem in some detail when he described Cibicides subhaidingerii, which is Holocene in age and distinct from the species identified here by virtue of a lower domed dorsal surface and the possession of too many chambers per whorl. This form is the same as that recorded by Cushman (1946) as Eponides haidingerii. It is not $G$. haidingerii as it has too many chambers (6-7) per whorl. It has a very high domed dorsal surface and an essentially flat ventral surface and thus illustrates very well the problems in the nomenclature of the genus Gyroidinoides.

\section{Gyroidinoides nitidus (Reuss), 1845}

(Plate 7, Figs. 10-11)

Rotalina nitida Reuss, 1845 , p. 35 , pl. 8 , fig. 52, and pl. 12, fig. 20 .

Gyroidina nitida (Reuss) Brotzen, 1936, p. 157, pl. 11, figs. 3a-c, and text fig. 58.

Gyroidina sp. cf. girardana (Reuss) Belford, 1960, p. 78, pl. 21, figs. $10-15$.

Gyroidinoides nitidus (Reuss) Sliter, 1968, p. 121, pl. 22, figs. 7a-c. Gyroidinoides nitidus (Reuss) McNeil and Caldwell, 1981, p. 281, pl. 24 , figs. $2 \mathrm{a}-\mathrm{c}$.

Gyroidinoides nitidus (Reuss) Basov and Krasheninnikov, 1983, p. 764 , pl. 9, figs. 2-3.

Remarks. This name is applied in the sense that it was used by Sliter (1968). This encompasses Belford's concept of $G$. sp. cf. girardana, which clearly was erroneous. The form illustrated by Belford is common on the Southern Kerguelen Plateau, and its nomenclature needs to be clarified.

Gyroidinoides girardanus sensu stricto has been well illustrated by McNeil and Caldwell (1981, pl. 24, figs. 1a-c), and its relationship to other species such as $G$. quadratus (Cushman and Church) outlined by Sliter (1968). The species exemplifies very well the points made above in the commentary introducing this genus.

Sliter provided a diagnosis of $G$. nitidus that allows Belford's concept of $G$. sp. cf. girardana to be included, and I think that application of that diagnosis gives a basis for a more consistent nomenclature.

\section{Gyroidinoides quadratus (Cushman and Church), 1929}

$$
\text { (Plate 7, Figs. 16-17) }
$$

Gyroidina quadrata Cushman and Church, 1929, p. 516, pl. 41, figs. 7-9. Gyroidinoides quadratus (Cushman and Church) Sliter, 1968, p. 121, pl. 22, figs. 8a-c.

Gyroidinoides quadratus (Cushman and Church) Basov and Krasheninnikov, 1983, p. 764, pl. 9, figs. 4-6.

Remarks. This species is a consistent component of faunas at Site 747 throughout the Campanian/Maestrichtian. It is a highly variable form, but it seems to evolve with time and is worthy of detailed study to document this. In its earliest occurrence, it seems almost to intergrade with an early form of Globorotalites umbilicatus. As time passes, it becomes relatively thicker, the shoulder becomes more acute and continuous, and the dorsal or spiral side develops a central boss that becomes more prominent with time. In the earlier forms (e.g., in Sample 120-750B-10W, $160 \mathrm{~cm}$ ), the final chambers lack a shoulder and have a rounded periphery. Although highly variable, there seems to have been little effort to document that variability. Sliter (1968) recognized some of the variation when he defined $G$. quadratus martini as a subspecies. Forms referable to $G$. quadratus martini were not seen here, but the individual features used to differentiate that subspecies have, albeit not within one population.

A feature not described previously is the presence of coarse pores on the ventral surface. Although scattered over the entire ventral surface, they seem to be concentrated around the umbilicus. Also not documented before is the variation in the features of the aperture.

\section{Gyroidinoides sp. 1 \\ (Plate 7, Figs. 18-19)}

Remarks. Included here are rare, small forms with a smooth, high domed or conical dorsal, or spiral surface and almost flat and involute ventral surface without any development of an umbilical boss. The correct generic placement is uncertain but in the past it would probably have been included in Eponides.

This species is very much like G. goudkoffi (Trujillo), but it has a more prominent conical dorsal surface; the ventral surface is then only weakly convex. It is also somewhat akin to Eponides concinna Brotzen, as recorded from Western Australia by Belford (1960). It has a very characteristic appearance, but it is rare wherever it occurs.

Gyroidinoides sp.

(Plate 7, Figs. 20-21)

Remarks. In Sample 120-750B-10W-1, $60 \mathrm{~cm}$, there is a form very closely allied to $G$. quadratus. It has the angled margin but lacks the development of a flange on that margin. It has six chambers per whorl. It was referred to above as being an apparently unnamed species.

\section{Genus NOTOPLANULINA Malumian and Masiuk, 1976}

\section{Notoplanulina aff. compressa (Sliter), 1968}

(Plate 7, Figs. 24-25)

?Gavelinella compressa Sliter, 1968 , p. 122, pl. 24, figs. $2 \mathrm{a}-\mathrm{c}$.

?Gavelinella compressa (Sliter) Basov and Krasheninnikov, 1983, p. 765 , pl. 10 , figs. $2-4$.

Remarks. Sliter (1968) described $N$. compressa to include those forms of the Upper Cretaceous that have a superficial resemblance to the modern Planulina ariminensis d'Orbigny. There is little doubt that most of what is included here comes within the definition he made. It occurs in Hole 747A from the youngest Campanian (Sample 120$747 \mathrm{~A}-25 \mathrm{X}-1,28-32 \mathrm{~cm}$ ) and continues downhole to $120-747 \mathrm{~A}-26 \mathrm{X}-3$, $28-32 \mathrm{~cm}$. At this level, although still within the upper Campanian, it gives way to $N$. rakauroana. The transition is not simple and some identifications could be debated. The differentiating features are taken to be that $N$. rakaurona is less evolute and thicker. It is also more planoconvex. Most of the specimens seem to be nonadult, as reflected in the smaller size and fewer chambers overall. The chambers often are more inflated on the dorsal surface than is normal in $N$. rakaurona.

\section{Notoplanulina rakauroana (Finlay), 1939}

(Plate 7, Figs. 22-23)

Planulina rakauroana Finlay, 1939, p. 326, pl. 29, figs. 154-156.

Planulina rakauroana (Finlay) Hornibrook, 1968, p. 45, fig. 5.

Notoplanulina rakaurona (Finlay) Malumian and Masiuk, 1976, p. 197, pl. 6, figs. 2a-d.

Notoplanulina rakauroana (Finlay) Loeblich and Tappan, 1987, p. 634, pl. 713, figs. 1-6.

Remarks. As pointed out above, this species seems to be ancestral to $N$. compressa (Sliter), and the transition is preserved in the section at Site 747, as it is in Argentina (Malumian and Masiuk, 1976). Preservation falls off downhole, and the species ranges from the lower Santonian to the upper Campanian.

A specimen was recovered (from Sample 120-748C-35R-1, 73-75 cm) that has a papillate ventral surface typical of such genera as Pileolina. 
Notoplanulina sp. 1

(Plate 7, Figs. 26-27)

Remarks. This form is characterized by its uniformly domed convex dorsal surface. It is much more highly domed than other species of the same genus. In other features it is typically $N$. rakaurona.

\section{Genus STENSIOEINA Brotzen, 1936}

The generic name has normally been spelled Stensioina, but in this study I have followed Loeblich and Tappan.

\section{Stensioeina beccariiformis (White) 1928}

(Plate 7, Figs. 28-29)

Rotalia beccariiformis White, 1928 , p. 287 , pl. 39, figs. 2a-4c. Pseudovalvulineria vombensis Brotzen, 1945, p. 50, pl. 1, figs. 12-13. Valvulineria erugatus Belford, 1960 , p. 76 , pl. 20, figs. 11-18. Valvulineria vombensis (Brotzen) McNulty, 1984 p. 558, pl. 2, fig. 5, and pl. 3, figs. 24-26.

Stensioina beccariiformis (White) van Morkhoven et al., 1986, p. 346 , pl. 113A, figs. 1a-c, pl. 113B, figs. 1a-2c, pl. 113C, figs. 1a-3b, and pl. $113 \mathrm{D}$, figs. $1 \mathrm{a}-4$

Remarks. This species is an important element in faunas throughout the Cretaceous at Site 747 . The nomenclature employed by van Morkhoven et al. (1986) is followed here, as I think it has done much to clarify the understanding of this species and its synonyms.

Belford (1960) described Valvulineria erugatus from the Santonian/Campanian of Western Australia. There is no evidence to suggest that it should not also be included within $S$. beccariiformis.

At about the level of Section 120-750B-6W-CC, this form gives way downhole to a less highly ornamented form, which is identified here as Stensioeina sp. 1.

Stensioeina sp. 1

(Plate 8, Figs. 1-2)

Remarks. As noted above, below Sample 120-750B-6W-CC, there is a form that is grossly identical with $S$. beccariiformis but can be differentiated on the decreased amount of ornamentation on the umbilicate side. Some specimens lack ornamentation completely. There is clearly a strong evolutionary link with $S$. beccariiformis.

\section{Genus GAVELINELLA Brotzen, 1942}

Gavelinella eriksdalensis (Brotzen), 1936 (Plate 8, Fig. 3)

Cibicides (Cibicidoides) eriksdalensis Brotzen, 1936, p. 193, pl. 14, figs. 5 and 69.

Anomalinoides eriksdalensis (Brotzen) Belford, 1960, p. 108, pl. 34 , figs. 1-11.

Anomalinoides canaliculus Belford, 1960, p. 103, pl. 31, figs. 1-15, and text fig. 10.

Gavelinella eriksdalensis (Brotzen) Sliter, 1968, p. 123, pl. 23, figs. $6 a-c$.

Remarks. This species occurs in the Maestrichtian and lates Campanian, as was noted by Sliter (1968). The range of variation in the ventral umbilical region is considerable, but the name has only been applied to those forms that obviously have a portion of the characteristic umbilical spiral structure. It is probable, as stated below, that some forms with a simpler umbilical structure were part of the same population. The individual samples seen in this study are not large enough to allow a definitive comment on range of variation. Because of the degree of variation possible, Anomalinoides canaliculus Belford is incorporated within this species.

\section{Gavelinella harperi (Sandidge), 1932}

(Plate 8, Figs. 6-7)

Anomalina harperi, Sandidge, 1932, p. 316, pl. 29, figs. 1-2. Cibicides harperi (Sandidge) Cushman, 1946, p. 159, pl. 65, figs. 5-7.

Remarks. This robust form occurs only in the upper Campanian and Maestrichtian of the section in Hole $748 \mathrm{C}$. It is generally poorly preserved and usually broken, with surface details somewhat obscured. The spiral surface is rather flat, either lacking surface structure in the umbilical region or with a weakly developed circum- umbilical canal. The opposite surface is domed and smooth with a central umbilicus that is flush with the surrounding surface and not prominent in any way. Periphery bluntly angled to rounded.

It differs from the species recorded by McNeil and Caldwell (1981) as Anomalina harperi in being less coarsely perforate dorsally and in having a less developed umbo on the dorsal side.

This is a rarely recorded species but is rather common in this section, perhaps reflecting the shallow-water environment.

Gavelinella nacatochensis (Cushman), 1938 (Plate 8, Figs. 9-10)

Planulina nacatochensis Cushman, 1938, p. 50, pl. 8, fig. 9. Gavelinella nacatochensis (Cushman) Sliter, 1968, p. 124, pl. 23, figs. 4-5.

Remarks. Three small, poorly preserved specimens in Sample $120-748 \mathrm{C}-36 \mathrm{R}-1,83-86 \mathrm{~cm}$.

\section{Gavelinella sandidgei (Brotzen), 1936} (Plate 8, Figs. 11-13)

Cibicides sandidgei Brotzen, 1936, p. 191, pl. 14, figs. 2-4. Gavelinella sandidgei (Brotzen) Sliter, 1968, p. 124, pl. 23, figs. 7-8.

Remarks. Sliter (1968) recognized two forms within this species. The same two forms occur in many of the samples examined in this study. The rarer form is a little more evolute, with a very shiny surface. It is identified as $G$. sandidgei form B. I find it difficult to accept that the two forms belong in the same species.

\section{Gavelinella stellula Belford, 1960 \\ (Plate 8, Fig. 14)}

Gavelinella stellula Belford, 1960, p. 110, pl. 33, figs. 11-18.

Remarks. A few specimens from the Maestrichtian can be referred to this species, which may be confused with $G$. eriksdalensis when both species are present. $G$. stellula may be an extreme variant of $G$. eriksdalensis; it is more involute, and the central umbilical spire is covered with the proximal extensions of the apertural flaps.

\section{Gavelinella stephensoni (Cushman), 1938 \\ (Plate 8, Figs. 15-16)}

Cibicides stephensoni Cushman, 1938, p. 70, pl. 12, fig. 5 .

Gavelinella stephensoni (Cushman) Sliter, 1069, p. 125, pl. 23, fig. 3.

Gavelinella stephensoni (Cushman) Basov and Krasheninnikov, 1983, p. 765 , pl. 10, figs. 5-6.

Remarks. Despite van Morkhoven et al. (1986) suggesting a synonymy between this form and Cibicidoides dayi (White), I have retained the separate status on the basis that the dorsal surface of $G$. stephensoni is only gently domed and the sutures on the dorsal surface are indistinct to the end.

\section{Gavelinella velascoensis (Cushman), 1925} (Plate 8, Fig. 20)

Anomalina velascoensis Cushman, 1925, p. 21, pl. 3, fig. 3 .

Anomalina velascoensis (Cushman) Cushman, 1946, p. 156, pl. 64, figs. $7 \mathrm{a}-\mathrm{c}$.

Gavelinella velascoensis (Cushman) van Morkhoven et al., 1986, p. 317 , pl. 121, figs. 1a-2d.

Remarks. The forms included here are quite diverse. They include typical adult forms of the species, but also younger forms that have all the features of the species but are not fully developed. In addition, there are a few large, robust, adult specimens that do not have all the characteristic features of the species fully developed. Coiling is both dextral and sinistral.

This species is a consistent component of faunas of the upper Campanian and Maestrichtian of Site 747. There it is associated with faunas of deeper water aspect than from older parts of the section.

Gavelinella sp. 1

(Plate 8, Figs. 22-23)

Remarks. This very characteristic but rare species has as its diagnostic feature a very prominent node on the central part of the ventral surface, the node expanding in diameter away from the ventral surface. The species is rare at Sites 747 and 750 . 
Generic identification is tentative as apertural details are not well preserved and other features, such as chamber and suture arrangement, are also consistent with identification as Osangularia. The choice of Gavelinella is based on the absence in the specimens recorded of any evidence of the characteristic murus reflectus of Osangularia.

Gavelinella sp. 2

(Plate 8, Figs. 24-25)

Remarks. Approximately $5 \%$ of the fauna in Sample $120-750$ A $24 \mathrm{R}-\mathrm{CC}$ is composed of this species, a small, robust form, relatively thick for the genus, and thick walled with a rounded periphery. There are about 11 chambers in the final whorl. The dorsal surface is slightly evolute with a circum-umbilical canal in the last few chambers. In this feature, it resembles $G$. eriksdalensis. It is much smaller, however. The ventral surface is involute with a small flush umbilical boss. The aperture sits astride the periphery and does not extend far on either side.

This form is a minor constituent of several other samples.

\section{SYSTEMATIC POSITION UNCERTAIN}

"Anomalina" nelsoni W. Berry, 1929

(Plate 8, Fig. 28)

Anomalina nelsoni W. Berry, 1929, p. 14, pl. 2, figs. 19-21.

Anomalina nelsoni (W. Berry) Cushman, 1946, p. 154, pl. 63, figs.

8-9.

Remarks. This form has been recorded from the Indian Ocean by Herb (1974), who used it as a basis for age determination. It is rare in the samples studied here. It is not very well preserved but is consistent with the illustration of Cushman (1946), especially his plate 63 , figure 9.

\section{SPECIES RECORDED WITHOUT COMMENT}

Alabamina dorsoplana $($ Brotzen $)=$ Eponides dorsoplana Brotzen, 1940 , p. 31 , fig. 8,2 = Alabamina dorsoplana (Brotzen) Sliter, 1968 , p. 116 , pl. 21 , fig. 5 .

Allomorphina sp.

Arenobulimina sp.

Bolivinoides draco draco (Marsson) = Bolivina draco Marsson, 1878, p. 157 , pl. 3, fig. $25=$ Bolivinoides draco draco (Marsson) Hiltermann and Koch, 1950, p. 598, fig. 1 (72-73), 2-4 (52-54 and $58-60)$, and 5 (53 and 69-70).

Bolivinoides granulata Hofker, 1957, p. 70, pl. 7, fig. 8 .

Bolivinoides sirticus Barr, 1970, p. 651, pl. 100, figs. 8-12.

Bolivinoides strigillatus $($ Chapman $)=$ Bolivina strigillata Chapman, 1892 , p. 515 , pl. 15 , fig. $10=$ Bolivinoides strigillata $($ Chapman) Hiltermann and Koch, 1950 , p. 614 , figs. 2 (1-19), 3 (1-9), and 5 (10).

Ceratobulimina cretacea Cushman and Harris, 1927, p. 173, pl. 29, figs. 1a-c; pl. 30, fig. 11 .

Ceratobulimina sp.

Citharina suturalis $($ Cushman) $=$ Vaginulina suturalis Cushman, 1937 b, p. 102 , pl. 15, figs. 5-7.

Clavulinoides sp. indet.

Coryphostoma midwayensis $($ Cushman $)=$ Bolivina midwayensis Cushman, 1936b, p. 50, pl. 7, fig. 112 = Coryphostoma midwayensis (Cushman) van Morkhoven et al., 1986, p. 364, pl. 118, figs. $1 \mathrm{a}-\mathrm{c}$

Dentalina basiplanata Cushman, 1938, p. 38, pl. 6, figs. 6-8.

Dentalina basitorta Cushman, 1938, p. 37, pl. 6, figs. 4-5.

Dentalina catenula Reuss, 1860 , p. 185, pl. 3, fig. 6 .

Dentalina confluens Reuss, 1862 , p. 335 , pl. 7 , fig. 5 .

Dentalina aff. consobrina d'Orbigny, 1846, p. 46, pl. 2, figs. 1-3.

Dentalina cylindroides Reuss, 1860 , p. 185 , pl. 1, fig. 8 .

Dentalina fallax Franke, 1928, p. 27, pl. 2, fig. 18.

Dentalina gracilis d'Orbigny, 1840, p. 14, pl. 1, fig. 5 .

Dentalina legumen Reuss, 1860, p. 187, pl. 3, fig. 5.

Dentalina aff. legumen Reuss.

Dentalina cf. sororia Reuss, 1860, p. 42.

Dentalina reflexa Morrow, 1934, p. 189, pl. 29, figs. 5 and 20.

Dentalina sp. B (sensu Belford), 1960, p. 35, pl. 10, figs. 15-16.

Dorothia biformis Finlay, 1939, p. 313, pl. 25, figs. 26-28.
Dorothia confraga Belford, 1960, p. 20, pl. 5, figs. 1-7.

Dorothia conicula Belford, 1960 , p. 20, pl. 5, figs. 8-13.

Ellipsoglandulina velascoensis Cushman, 1926b, p. 590, pl. 16, figs. $7 \mathrm{a}-\mathrm{b}$

Ellipsoidella binaria Belford, 1960, p. 71, pl. 19, figs. 14-22.

Ellipsoidella gracillima $($ Cushman $)=$ Nodosarella gracillima Cush man, 1933b, p. 64 , pl. 17 , fig. 14

Ellipsoidella solida $($ Brotzen $)=$ Nodosarella solida Brotzen, 1936, $\mathrm{p}$. 140 , pl. 9, figs. 11a-b.

Eouvigerina hispida Cushman, 1931b, p. 45, pl. 7, figs. 12-13.

Eouvigerina aff. rosarioensis Sliter, 1968, p. 90, pl. 13, fig. 8.

Fissurina sp.

Frondicularia archiaciana d'Orbigny, 1840, p. 20, pl. 1, figs. 34-36.

Frondicularia intermittens Reuss, 1866, p. 460, pl. 1, fig. 11.

Frondicularia aff. lanceola Reuss, 1860, p. 198, pl. 5, figs. 1a-b.

Frondicularia aff. steinekei Finlay, $1939=F$. sp. cf. steineckei Finlay. Belford, 1960, p. 49, pl. 13, figs. 9-11

Frondicularia sp.

Gaudryina sp.

Gavelinella excavatus (Brotzen) = Cibicides excavata Brotzen, 1936, p. 189 , pl. 13 , figs. $7 \mathrm{a}-\mathrm{c}$ and $8 \mathrm{a}-\mathrm{c}$.

Gavelinella insculpta Belford, 1960, p. 109, pl. 33, figs. 1-10.

Gavelinella aff. trujilloi (Sliter) $=$ ?Gyroidinoides trujilloi Sliter, 1968, p. 122 , pl. 23 , figs. la-c.

Glandulina manifesta Reuss, 1851, p. 22, pl. 1, fig. 4.

Glandulina sp.

Globimorphina sp.

Globorotalites sp.

Globulina lacrima (Reuss) = Polymorphina (Globulina) lacrima Reuss, 1845 , p. 40 , pl. 12 , fig. 6 , and pl. 13 , fig. 83 .

Globulina prisca Reuss, 1862 , p. 79 , pl. 9, fig. 8a-b.

Globulina subsphaerica (Berthelin) = Polymorphina subsphaerica Berthelin, 1880 , p. 58 , pl. 4 , fig. 18.

Guttulina adhaerens $($ Olszewski $)=$ Polymorphina adhaerens Olszewski, 1875, p. 119, pl. 1, fig. 11 .

Gyroidinoides exserta $($ Belford $)=$ Gyroidina exsert $a$ Belford, 1960, p. 80 , pl. 22 , figs. $1-6$

Gyroidinoides goudkoffi (Trujillo) = Eponides goudkoffi Trujillo, 1960 , p. 333 , pl. 48 , fig. 6 .

Gyroidinoides noda $($ Belford $)=$ Gyroidina noda Belford, 1960, p. 79 pl. 21, figs. 16-27.

Haplophragmoides/Trochammina undifferentiated.

Lagena acuticosta Reuss, 1862, p. 305, pl. 1, fig. 4.

Lagena aspera Reuss, 1862 , p. 305 , pl. 1, fig. 5 .

Lagena cf. hispida Reuss, 1863, p. 335, pl. 6, figs. 77-79.

Lagena paucicosta Franke = Lagena amphora Reuss var. paucicosta Franke, 1928, p. 87 , pl. 7, fig. 38 .

Lagena semiinterrupta Berry = Lagena sulcata $($ Walker and Jacob) var. semiinterrupta Berry, 1929, p. 5, pl. 3, fig. 19.

Lagena sidebottomi Earland, 1934, p. 161, pl. 7, fig. 23.

Lagena sp. indet.

Lenticulina acutauriculus (Fichtel and Moll) $=$ Nautilus acutauriculus Fichtel and Moll, 1798, p. 102, pl. 18, figs. g-i.

Lenticulina discrepans (Reuss) $=$ Robulina discrepans Reuss, 1863 , p. 78, pl. 7, figs. 7a-b.

Lenticulina macrodiscus (Reuss) = Cristellaria macrodisca Reuss 1863 , p. 78 , pl. 9 , figs. 5 a-b.

Lenticulina navicula (d'Orbigny) = Cristellaria navicula d'Orbigny 1840 , p. 27 , pl. 2 , figs. $19-20$.

Lingulina sp.

Loxostomum eleyi $($ Cushman $)=$ Bolivinita eleyi Cushman, $1927, \mathrm{p}$. 91 , pl. 12, fig. 11.

Loxostomum sp.

Marginulina bullata Reuss, 1845 , p. 29 , pl. 13, figs. 34-38.

Marginulina cretacea Cushman, 1937c, p. 94, pl. 13, figs. 12-15

Marginulina curvatura Cushman, 1938, p. 34, pl. 5, figs. 13-14.

Marginulina inconstantia Cushman, 1938, p. 33, pl. 5, figs. 4-9.

Marginulina jarvisi Cushman, 1938, p. 598, pl. 19, fig. la-b.

Marginulina sp. indet.

Marginulina(?) sp.

Marginulinopsis texasensis $($ Cushman $)=$ Marginulina texana Cush man, 1937c, p. 95 , pl. 14, figs. 1-4

Neoflabellina rugosa (d'Orbigny) = Flabellina rugosa d'Orbigny, 1840 , p. 23 , pl. 2 , figs. $4-5$ and 7. 
Nodosaria aspera Reuss, 1845, p. 26, pl. 13, figs. 14-15.

Nodosaria limbata d'Orbigny, 1840, p. 12, pl. 1, fig. 1.

Nodosaria paupercula Reuss, 1845, p. 26, pl. 12, fig. 12

Nodosaria prismatica Reuss, 1860 , p. 180 , pl. 2 , fig. 2 .

Nodosaria septemcostata Geinitz, 1842, p. 69, pl. 17, fig. 20.

Nuttallinella coronula (Belford) = Nuttallina coronula Belford, 1958a, p. 97, pl. 19, figs. 1-14.

Oolina apiculata Reuss, 1851, p. 22, pl. 2, fig. 1.

Oolina globosa $($ Montagu $)=$ Vermiculum globosum Montagu, 1803 , p. $523=$ Lagena globosa $($ Montagu), Brotzen, 1936, p. 109, pl. 7, fig. 3 .

?Oolina sp.

Osangularia aff. cordieriana (d'Orbigny)

Osangularia velascoensis (Cushman) $=$ Truncatulina velascoesis Cushman, 1925, p. 20, pl. 3, fig. 2.

Patellina subcretacea Cushman and Alexander, 1930, p. 10, pl. 3, fig. 1.

Planularia dissona $($ Plummer $)=$ Astacolus dissona Plummer, 1931, p. 145 , pl. 11, figs. 17-18, and pl. 15, figs. 2-7.

Pleurostomella aff. primitiva $($ Cushman $)=$ Nodosarella primitiva Cushman, 1938, p. 46, pl. 8, fig. 2.

Pleurostomella subnodosa Reuss, 1860, p. 204, pl. 8, fig. 2.

Pleurostomella indet.

Praebulimina aspera (Cushman and Parker) = Bulimina aspera Cushman and Parker, 1940, p. 44, pl. 8, fig. 18-19.

Praebulimina aff. cushmani (Sandidge) = Buliminella cushmani Sandidge, 1932 , p. 280 , pl. 42 , figs. $18-19$.

Praebulimina carseyae $($ Plummer) $=$ Buliminella carseyae Plummer, 1931 , p. 179 , pl. 8 , fig. 9.

Praebulimina kickapooensis $($ Cole $)=$ Bulimina kickapooensis Cole, 1938 , p. 45 , pl. 3 , fig. 5 .

Praebulimina spinata $($ Cushman and Campbell $)=$ Bulimina spinata Cushman and Campbell, 1935, p. 72, pl. 11, fig. 1.

Praebulimina trinitatensis $($ Cushman and Jarvis) $=$ Bulimina trinitatensis Cushman and Jarvis, 1928, p. 102, pl. 14, fig. 12a-b.

Pseudoclavulina sp. indet.

Pullenia americana Cushman, 1936a, p. 76, pl. 13, figs. 4a-b and 5a-b.

Pyramidina rudita (Cushman and Parker) = Bulimina ornata Cushman and Parker, 1935, p. 97, pl. 15, fig. $4=$ Bulimina rudita Cushman and Parker, 1936, p. 45.

Pyramidina szajnochae (Grzybowski) = Verneuilina szajnochae Grzybowski, 1896, p. 28, pl. 9, fig. $19=$ Reussella szajnochae (Grzybowski). Belford, 1960, p. 66, pl. 16, figs. 16-19, and pl. 17, figs. 1-13.

Pyramidina triangularis $($ Cushman and Parker $)=$ Bulimina triangularis Cushman and Parker, 1935, p. 97, pl. 15, fig. 4

Pyramidina sp. 1.

Pyrulina cylindroides (Roemer) $=$ Polymorphina cylindroides Roemer, 1838 , p. 385 , pl. 3 , fig. 26 .

Quadrimorphina allomorphinoides (Reuss) $=$ ?Valvulineria allomorphinoides Reuss, 1860 , p. 223 , pl. 11, fig. 6.

Ramulina cf. navarroana Cushman, 1938, p. 43, pl. 7, figs. 10-11.

Saccammina sp.

"Saccammina" sp.

Saracenaria triangularis (d'Orbigny) $=$ Cristellaria triangularis d'Orbigny, 1840 , p. 27 , pl. 2 , fig. $21-22$.

Saracenaria sp.

Stilostomella alexanderi (Cushman) = Ellipsonodosaria alexanderi Cushman, 1936b, p. 52, pl. 9, figs. 6-9.

Stilostomella stephensoni $($ Cushman $)=$ Ellipsonodosaria stephensoni Cushman, 1936b, p. 52, pl. 9, figs. 10-15.

Vaginulina navarroana Cushman, 1936, p. 416, pl. 1, fig. 3.

Vaginulina paucistriata Reuss, 1863 , p. 48 , pl. 3, figs. 16a-c.

Vaginulina aff. wadei Kelley in Berry and Kelley, 1929, p. 8, pl. 1, fig. 7.

Vaginulina sp.

?Valvulineria sp.

Valvulineria infrequens Morrow, 1934, p. 197, pl. 30, figs. 3a-c.

\section{SUMMARY AND CONCLUSIONS}

Benthic foraminifer faunas are documented with figures and, where relevant, discussion from Upper Cretaceous (Cenomanian-Maestrichtian) sections in holes at Sites 747, 748, and 750. Over 200 species are recorded. Paleoenvironment and its change are identified, using data from foraminifer fauna composition and structure (including some information from planktonic faunas), other fossil content, and lithologic features recorded in Schlich, Wise, et al. (1989). No attempt was made to incorporate oxygen isotope or other geochemical data. Age information for the sections is based on planktonic foraminifers and calcareous nannofossils. Faunas generally represent environments shallower than those drilled by ODP in Cretaceous sections as they occur on a major submarine plateau that was much shallower at the time than it is now.

Foraminifer faunas are generally of species well known elsewhere, and no new species are erected although Conorboides sp. (upper Campanian at each of the three sites) and Notoplanulina n. sp. are noted, discussed, and illustrated. A species of Stensioeina, identified here as $S$. sp. 1 predates $S$. beccariiformis and is taken as its ancestor. $S$. beccariiformis is the dominant form in the Campanian/Maestrichtian of Site 747 and in samples at and above the lower Maestrichtian at Site 750. Below sections with dominant $S$. beccariiformis, Gavelinella eriksdalensis, or a variety of species of Praebulimina or Gyroidinoides are dominant at both sites. Gavelinella sandidgei and Alabamina australis are dominant in the postTuronian faunas at Site 748 and species of Saccammina where foraminifers occur below that depth.

Faunas at Site 747 accumulated in open-ocean, lower to upper bathyal conditions where water depths increased with time. Planktonic species normally constitute $>95 \%$ of the total foraminifer faunas. Site 750 also shows evidence of increasing water depth with time but in a shallower range, from outer shelf to upper bathyal. Again, planktonic species usually constitute over $95 \%$. Conditions at Site 748 were very different, always shallow (inner shelf) with planktonic species present in small numbers and their presence sporadic. This site was close to exposed land until at least Turonian, time as judged by the presence of a noteworthy component of fossil wood in residues.

Sections at all three sites are marked by unconformities, but too few data are available to provide a basis for the correlation of unconformities, most of which appear to be of local extent.

A major tectonic event occurred around the CretaceousTertiary transition leading to the relatively abrupt descent of the Southern Kerguelen Plateau into significantly deeper water, ooze-forming conditions, even at Site 748 .

\section{ACKNOWLEDGMENTS}

I thank my daughter Marian for her assistance in so many facets of the tedious work of preparing and assembling the plates; Bob Reeves of the Australian Antarctic Division (AAD) for his continuing aid with photography; Andrew McEldowney and Geraldine Nash (AAD) for help with electron microscopy; Pat Waddington (AAD) for all the diverse support at the office; and the shipboard company who made the whole thing a great experience.

\section{REFERENCES}

Barker, R. W., 1961. Taxonomic notes on the species figured by H. B. Brady in his report on the foraminifera dredged by H.M.S. Challenger during the years 1873-1876. Spec. Publ.-Soc. Econ. Paleontol. Mineral., 9:1-238.

Barr, F. T., 1970. The foraminiferal genus Bolivinoides from the Upper Cretaceous of Libya. J. Paleontol., 44:642-654.

Barron, J., Larsen, B., et al., 1989. Proc. ODP, Init. Repts., 119: College Station, TX (Ocean Drilling Program).

Basov, I. A., and Krasheninnikov, V. A., 1983. Benthic foraminifers in Mesozoic and Cenozoic sediments of the southwestern Atlantic as an indicator of paleoenvironment, Deep Sea Drilling Project 
Leg 71. In Ludwig, W. J., Krasheninnikov, V. A., et al., Init. Repts. DSDP, 71, Pt. 2: Washington (U.S. Govt. Printing Office), 739-788.

Bassias, Y., Davies, H. L., Leclaire, L., and Weis, D., 1987. Basaltic basement and sedimentary rocks from the southern sector of the Kerguelen-Heard Plateau: new data and their Meso-Cenozoic paleogeographic and geodynamic implications. Bull. Mus. Natl. Hist. Nat., Sect. C, 9:367-403.

Belford, D. J., 1958a. The genera Nutallides Finlay 1939, and Nuttallina n. gen. Contrib. Cushman Found. Foraminiferal Res., 9:9398.

1958b. Stratigraphy and micropalaeontology of the Upper Cretaceous of Western Australia. Geol. Rundsch., 47:629-647. 1959. Nuttallinella, new name for Nuttallina Belford, 1958 (non Nuttallina Dall, 1871). Contrib. Cushman Found. Foraminiferal Res., 10:20.

1960. Upper Cretaceous foraminifera from the Toolonga Calcilutite and Gingin Chalk, Western Australia. Bull.-Bur. Miner. Resour., Geol. Geophys. (Aust.), 57:1-198.

Berry, E. W., 1929. Larger foraminifera of the Verdun Formation of northwestern Peru. Johns Hopkins Univ. Stud. Geol., 9:9-166.

Berry, E. W., and Kelley, L., 1929. The foraminifera of the Ripley Formation of Coon Creek, Tennessee. Proc. U.S. Nat. Mus., 76: article 19.

Berthelin, G., 1880. Memoire sur les foraminiferes fossiles de l'Etage Albien de Moncley (Doubs). Mem. Soc. Geol. Fr., Ser.3, 1:1-84.

Brady, H. B., 1879. Notes on some of the reticularean Rhizopoda of the Challenger Expedition. Part II: additions to knowledge of the porcellanous and hyaline types. Quart. J. Microsc. Sci., 19:261299.

1881. Notes on some of the reticularean Rhizopoda of the Challenger Expedition. Part III. 1. Classification. 2. Further notes on new species. 3. Note on Biloculina mud. Quart. J. Microsc. Sci.. 21:31-71.

1884. Report on the Foraminifera dredged by H.M.S. Challenger, during the years 1873-1876. Rep. Sci. Results Challenger Exped., Zool., 9:1-814.

Brotzen, F., 1936. Foraminiferen aus dem Schwedischen untersten Senon von Eriksdal in Schonen. Arsb. Sver. Geol. Unders., Ser. C, 396:1-206.

1940. Flintrännans och Trindelrännans Geologi (öresund). Arsb. Sver. Geol. Unders., Ser. C, 435:1-33.

1945. De geologiska resultanten fran borrningarna vid Hollviken; Preliminar Rapport. del. 1. Arsb. Sver. Geol. Unders., Ser. C, 493:1-140.

Burckle, L. H., Saito, T., and Ewing, M., 1967. A Cretaceous (Turonian) core from the Naturaliste Plateau, southeast Indian Ocean. Deep Sea Res. Oceanogr. Abstr., 14:421-426.

Chapman, F., 1892. Microzoa from the Phosphatic Chalk of Taplow. Q. J. Geol. Soc. London, 48:514-518.

Cole, W. S., 1938. Stratigraphy and micropaleontology of two deep wells in Florida. Bull. Geol. Surv. Florida, 16:1-73.

Cushman, J. A., 1925. Some new foraminifera from the Velasco Shale of Mexico. Contrib. Cushman Lab. Foraminiferal Res., 1:18-22.

1926a. Some foraminifera from the Mendez Shale of eastern Mexico. Contrib. Cushman Lab. Foraminiferal Res., 2:16-26.

1926b. The foraminifera of the Velasco Shale of the Tampico Embayment. AAPG Bull., 10:581-612.

, 1927. American Upper Cretaceous species of Bolivina and related species. Contrib. Cushman Lab. Foraminiferal Res., 2:8591 .

1931a. The foraminifera of the Saratoga Chalk. J. Paleontol., 5:297-315.

1931b. A preliminary report on the foraminifera of Tennessee. Bull. Tennessee Div. Geol., 41:5-112.

1932a. Textularia and related forms from the Cretaceous. Contrib. Cushman Lab. Foraminiferal Res., 8:86-97.

, 1932b. The foraminifera of the Annona Chalk. J. Paleontol., 6:330-345.

1933a. Some new foraminiferal genera. Contrib. Cushman Lab. Foraminiferal Res., 9:32-38.

1933b. New American Cretaceous foraminifera. Contrib. Cushman Lab. Foraminiferal Res., 9:49-64. 1936a. Cretaceous foraminifera of the Family Chilostomellidae. Contrib. Cushman Lab. Foraminiferal Res., 12:71-78.

1936b. New genera and species of the families Verneuilinidae and Valvulinidae and of the subfamily Virgulininae. Spec. Publ. Cushman Lab. Foraminiferal Res., 6:1-71.

1937a. A monograph of the foraminiferal Family Verneuilinidae. Spec. Publ. Cushman Lab. Foraminiferal Res., 7:1-157. , 1937b. A few new species of American Cretaceous foraminifera. Contrib. Cushman Lab. Foraminiferal Res., 13:100-105. $1937 \mathrm{c}$. Some notes on Cretaceous species of Marginulina. Contrib. Cushman Lab. Foraminiferal Res., 13:91-99.

1938. Additional new species of American Cretaceous foraminifera. Contrib. Cushman Lab. Foraminiferal Res., 14:3152.

1946. Upper Cretaceous foraminifera of the Gulf Coastal region of the United States and adjacent areas. Geol. Surv. Prof. Pap. U.S., 206:1-241.

Cushman, J. A., and Campbell, A. S., 1935. Foraminifera from the Moreno Shale of California. Contrib. Cushman Lab. Foraminiferal Res., 11:65-73.

Cushman, J. A., and Church, C. C., 1929. Some Upper Cretaceous foraminifera from near Coalinga, California. Proc. Calif. Acad. Sci. Ser. 4, 18:497-530.

Cushman, J. A., and Harris, R. W., 1927. Some notes on the genus Ceratobulimina. Contrib. Cushman Lab. Foraminiferal Res., 3:171-179.

Cushman, J. A., and Jarvis, P. W., 1928. Cretaceous foraminifera from Trinidad. Contrib. Cushman Lab. Foraminiferal Res., 4:85103.

Cushman, J. A., and Parker, F. L., 1935. Some American Cretaceous buliminas. Contrib. Cushman Lab. Foraminiferal Res., 11:96-101. 1936. Some American Eocene buliminas. Contrib. Cushman Lab. Foraminiferal Res., 12:39-45. 1940. New species of Bulimina. Contrib. Cushman Lab. Foraminiferal Res., 16:44-48.

d'Orbigny, A., 1840. Memoire sur les Foraminiferes de la craie blanche du Bassin de Paris. Mem. Soc. Geol. Fr., 4:1-51.

1846. Foraminiferes Fossiles du Bassin Tertiaire de Vienne (Autriche): Paris (Gide and Co.).

Douglas, R. G., and Woodruff, F., 1981. Deep-sea benthic foraminifera. In Emiliani, C. (Ed.), The Sea (Vol. 7): New York (WileyInterscience), 1233-1327.

Earland, A., 1934. Foraminifera, Pt. 3. The Falklands sector of the Antarctic (excluding South Georgia). Discovery Rep., 10:1-208.

Ehrenberg, C. G., 1854. Mikrogeologie: Das Erden und Felsen Schaffende Wirken des Unsichtbar Kleines Selbständigen Lebens auf der Erde: Leipzig (Leopold Voss).

Fichtel, L., and Moll, J.P.C., 1798. Testacea Microscopica, Aliaque Minuta Ex Generibus Argonauta, Ad Naturam Picta Descripta: Vienna (Camesina).

Finlay, H. J., 1939. New Zealand foraminifera: key species in stratigraphy, No. 3. Trans. R. Soc. N. Z., 69:309-329.

Fisher, M. J., 1969. Benthonic foraminifera from the Maestrichtian chalk of Galicia Bank, west of Spain. Palaeontology, 12:189-200.

Franke, A., 1928. Die Foraminiferan der oberen Kreide Nord-und Mittel-deutschlands. Abh. Preuss. Geol. Landesanst., n. ser., 111:1-207.

Frizzell, D., 1943. Upper Cretaceous foraminifera from northwestern Peru. J. Paleontol., 17:331-353.

Geinitz, H. B., 1842. Charakteristik der Schichten und Petrefacten des sächsisch-böhmischen Kreidegebirges. Dresden and Leipzig (the author), vol. 3 .

Geological Survey of Western Australia, 1975. The geology of Western Australia. Mem. Geol. Surv. West. Aust., 2:1-541.

Grzybowski, J., 1896. Otwornice czerwonych ilow z Wadowic. Akademija umiejetnosci $w$ Krakowie Wydzial matematyczno przyrodniczy. 30, Ser.2, 10:261-308.

1897. Otwornice pokladow naftonosynch okolicy Krosna. Akademija umiejetnosci $w$ Krakowie Wydzial matematycznoprzyrodniczy, 33, Ser. 2, 13:257-305.

Hemleben, C., and Troester, J., 1984. Campanian-Maestrichtian deep-water foraminifers from Hole 534A, Deep Sea Drilling Project. In Biju-Duval, B., Moore, J. C., et al., Init. Repts. DSDP, 78A: Washington (U.S. Govt. Printing Office), 509-532. 
Herb, R., 1974. Cretaceous planktonic foraminifera from the eastern Indian Ocean. In Davies, T. A., Luyendyk, B. P., et al., Init. Repts. DSDP, 26: Washington (U.S. Govt. Printing Office), 745770.

Hiltermann, H., and Koch, W., 1950. Taxonomic und Vertikalverbreitung von Bolivinoides-Arten im Senon Nordwestdeutschlands. Geol. Jahrb., 64:595-632.

Hofker, J., 1957. Foraminiferen der Oberkreide von Nordwestdeutschland und Holland. Geol. Jahrb. Beih., 27:1-464.

Hornibrook, N. de B., 1968. A handbook of New Zealand microfossils (Foraminifera and Ostracoda). Information Ser. Handbook, N. Z. Geol. Surv., 62:1-136.

Hornibrook, N. de B., Brazier, R. C., and Strong, C. P., 1989. Manual of New Zealand Permian to Pleistocene foraminiferal biostratigraphy. Paleontol. Bull. N. Z. Geol. Surv., 56:1-175.

Huber, B. T., 1988. Upper Campanian-Paleocene foraminifera from the James Ross Island region, Antarctic Peninsula. In Feldmann, R. M., and Woodburne, M. O. (Eds.), Geology and Paleontology of Seymour Island, Antarctica. Mem. Geol. Soc. Am., 169:163252.

Jennings, P. H., 1936. A microfauna from the Monmouth and basal Rancocas groups of New Jersey. Bull. Am. Paleontol., 23:161232.

LeClaire, L., Bassias, Y., Denis-Clochiatti, M., Davies, H. L., Gautier, I., Gensous, B., Giannesini, P.-J., Patriat, P., Ségoufin, J., Tesson, M., and Wannesson, J., 1987. Lower Cretaceous basalt and sediments from the Kerguelen Plateau. Geo-Mar. Lett., 7:169-176.

Leg 120 Shipboard Scientific Party, 1988. That sinking feeling. $\mathrm{Na}$ ture, 334:385-386.

Loeblich, A. R., Jr, and Tappan, H., 1987. Foraminiferal Genera and Their Classification: New York (Van Nostrand Reinhold).

Loetterle, G. J., 1937. The micropaleontology of the Niobrara Formation of Kansas, Nebraska and South Dakota. Bull. Neb. Geol. Surv., Ser. 2, 12:1-73.

Logan, B. W., Brown, R., and Quilty, P. G., 1976. Carbonate sediments of the west coast of Western Australia. Excursion Guide, Int. Geol. Congr., No. 37A.

Malumian, N., Echevarria, A., Martinez Macchiavello, J. C., and Nañez, C., 1984. Los Microfosiles. IX Congr. Geol. Argent. (1984), 485-526.

Malumian, N., and Masiuk, V., 1976. Foraminiferos de la Formaçion Cabeza de Leon (Cretacico Superior, Tierra del Fuego, rep. Argentina). Rev. Asoc. Geol. Argent., 31:180-202.

Marie, P., 1941. Les foraminiferes de la Craie a Belemnitella mucronata du Bassin de Paris. Mem. Mus. Nat. Hist. Nat., 12:1-296.

Marsson, T., 1878. Die Foraminiferen der weissen Schreibkreide der Inseln Rügen. Mitt. Naturwiss. Vereins Neu-Vorpomniem und Rugen in Greifswald, 10:115-196.

McFadyen, W. A., 1933. Miocene foraminifera from the Clysmic area of Egypt and Sinai. Geol. Surv. Egypt, 1-148.

McGugan, A., 1964. Upper Cretaceous zone foraminifera, Vancouver Island, British Columbia, Canada. J. Paleontol., 38:933-951.

McNeil, D. H., and Caldwell, W.G.E., 1981. Cretaceous rocks and their foraminifera in the Manitoba Escarpment. Spec. Pap. Geol. Assoc. Can., 21:1-439.

McNulty, C. L., 1984. Cretaceous foraminifers of Hole 530A, DeepSea Drilling Project. In Hay, W. W., Sibuet, J.-C., et al., Init. Repts. DSDP, 75: Washington (U.S. Govt. Printing Office), 547564 .

Mello, J. F., 1969. Foraminifera and stratigraphy of the upper part of the Pierre Shale and lower part of the Fox Hills Sandstone (Cretaceous) north-central South Dakota. Geol. Surv. Prof. Pap. U.S., 611:1-121.

Montagu, G., 1803. Testacea Britannica, or Natural History of British Shells, Marine, Land, and Fresh-water, Including the Most Minute: Romsey, Great Britain (J. S. Hollis).

Morrow, A. L., 1934. Foraminifera and Ostracoda from the Upper Cretaceous of Kansas. J. Paleontol., 8:186-205.

Olsson, R. K., and Nyong, E. E., 1984. A paleoslope model for Campanian-Lower Maestrichtian foraminifera of New Jersey and Delaware. J. Foraminiferal Res., 14:50-68.

Olszewski, S., 1875. Zapiski paleontologiczne. Akad. Umietejetnosci w Krakowie Sprawozd. Kom. Fizyjogr., 9:95-149.
Parr, W. J., 1950. Foraminifera. Rep. B.A.N.Z. Antarc. Res. Exped., Ser. B, 5:233-392.

Patterson, R. T., and Richardson, R. H., 1987. A taxonomic revision of the unilocular foraminifera. J. Foraminiferal Res., 17:212-226.

Playford, P. E., Cockbain, A. E., and Low, G. H., 1976. Geology of the Perth Basin, Western Australia. Bull. Geol. Surv. West. Aust., 124:1-311.

Quilty, P. G., 1973. Cenomanian-Turonian and Neogene sediments from northeast of Kerguelen Ridge, Indian Ocean. J. Geol. Soc. Aust., 20:361-368.

1978. The Late Cretaceous-Tertiary section in Challenger No. 1 (Perth Basin): details and implications. In Belford, D. G., and Scheibnerova, V. (Eds.), The Crespin Volume: Essays in Honour of Irene Crespin. Bull. Bur. Miner. Resour., Geol. Geophys. (Aust.), 192:109-135.

1984. Cretaceous foraminiferids from Exmouth Plateau and Kerguelen Ridge, Indian Ocean. Alcheringa, 8:225-241.

1990. Triassic and Jurassic foraminiferal faunas, northern Exmouth Plateau, eastern Indian Ocean. J. Foraminiferal Res.

Reuss, A. E., 1845. Die Versteinerungen der Böhmischen Kreideformation (Vol. 1): Stuttgart (E. Schweizerbart).

1851. Uber die fossilen Foraminiferen und Entomostraceen der Septarienthone der umgegend von Berlin. Z. Dtsch. Geol. Ges, . 8:49-92.

1860. Die Foraminiferen der Westphaelischen Kreideformation. Sitzungsber. Kais. Akad. Wiss. Wien Math.-Naturwiss. Kl., 40:147-238.

1862. Palaeontologische Beiträge. Sitzungsber. Kais. Akad. Wiss. Wien Math.-Naturwiss. Kl., 44:301-342. 1863. Die Foraminiferen des norddeutschen Hils und Gault. Sitzungsber. Kais. Akad. Wiss. Wien Math.-Naturwiss. Kl., 46:5100.

1866. Die Foraminiferen und Ostrakoden der Kreide am Kanara-See bei Küstendsche. Sitzungsber. Kais. Akad. Wiss. Wien Math.-Naturwiss. Kl., 52:445-470.

Roemer, F. A., 1838. Die Cephalopoden des norddeutschen tertiaeren Meeressandes. Neues Jahrb. Miner., 381-394.

1841. Die Versteinerungen des Norddeutschen Kreidegebirges: Hannover (Hahn).

Royer, J.-Y., and Sandwell, D. T., 1989. Evolution of the eastern Indian Ocean since the Late Cretaceous: constraints from GEOSAT altimetry. J. Geophys. Res., 94:13755-13782.

Sanders, H. L., 1968. Marine benthic diversity: a comparative study. Am. Nat., 102:243-282.

Sandidge, J. R., 1932. Foraminifera from the Ripley formation of western Alabama. J. Paleontol., 6:265-287.

Scheibnerova, V., 1974. Aptian-Albian benthonic foraminifera from DSDP Leg 27, Sites 259, 260 and 263, eastern Indian Ocean. In Veevers, J. J., Heirtzler, J. R,, et al., Init. Repts. DSDP, 27: Washington (U.S. Govt. Printing Office), 697-742.

1978. Some Cretaceous foraminifera from Leg 26 of the DSDP in the Indian Ocean. In Belford, D. G., and Scheibnerova, V. (Eds.), The Crespin Volume: Essays in Honour of Irene Crespin. Bull. Bur. Miner. Resour., Geol. Geophys. (Aust.), 192:137-162.

Schlich, R., Wise, S. W., Jr., et al., 1989. Proc. ODP, Init Repts., 120: College Station, TX (Ocean Drilling Program).

Sclater, J. G., Abbot, D., and Thiede, J., 1977. Paleobathymetry and sediments of the Indian Ocean. In Heirtzler, J., Bolli, H. M., Davies, T. A., Saunders, J. B., and Sclater, J. G. (Eds.), Indian Ocean Geology and Biostratigraphy. Am. Geophys. Union, 2559.

Sliter, W. V., 1968. Upper Cretaceous foraminifera from southern California and northwestern Baja California, Mexico. Univ. Kansas Paleontol. Contrib., 49:1-141.

1972. Cretaceous bathymetric distribution of benthic foraminifers. J. Foraminiferal Res., 2:167-183.

1976. Cretaceous foraminifers from the southwestern Atlantic Ocean, Leg 36, Deep Sea Drilling Project. In Barker, P. F., Dalziel, I.W.D., et al., Init. Repts. DSDP, 36: Washington (U.S. Govt. Printing Office), 519-573.

1985. Cretaceous redeposited benthic foraminifers from Deep Sea Drilling Project Site 585 in the East Mariana Basin, western equatorial Pacific, and implications for the geologic his- 
tory of the region. In Moberly, R., Schlanger, S. O., et al., Init. Repts. DSDP, 89: Washington (U.S. Govt. Printing Office), 327-361.

Smith, A. G., Hurley, A. M., and Briden, J. C., 1981. Phanerozoic Paleocontinental World Maps: Cambridge (Cambridge Univ. Press).

Taylor, D. J., 1964. Foraminifera and the stratigraphy of the western Victoria Cretaceous sediments. Proc, R. Soc, Victoria, 77:535-602.

Troelsen, J. C., 1954. Studies on Ceratobuliminidae (Foraminifera). Dansk. Geol. Foren. Medd., 12:448-478.

Trujillo, E. F., 1960. Upper Cretaceous foraminifera from near Redding, Shasta County, California. J. Paleontol., 34:290-346.

Upshaw, C. F., and Stehli, F. G., 1962. Quantitative biofacies mapping. AAPG Bull., 46:694-699.

van Morkhoven, F.P.C.M., Berggren, W. A., Edwards, A. S., et al., 1986. Cenozoic cosmopolitan deep-water benthic foraminifera. Bull. Cent. Rech. Explor.-Prod. Elf-Aquitaine, Mem. 11.
Veevers, J. J. (Ed.), 1984. Phanerozoic Earth History of Australia: Oxford (Clarendon Press).

von Hagenow, F., 1842. Monographie der Rügen'schen KreideVersteinerungen; Abt III-Mollusken. Neues Jahrb. Mineralogie, Geognosie, Geologie Petrefakten-Kunde (1842):528-575.

Walton, W. R., 1964. Recent foraminiferal ecology and paleoecology. In Imbrie, J., and Newell, N. D. (Eds). Approaches to Paleoecology: New York (Wiley), 151-237.

White, M. P., 1928. Some index foraminifer of the Tampico Embayment of Mexico (Part 2). J. Paleontol., 2:208-317.

Date of initial receipt: 30 April 1990

Date of acceptance: 20 September 1990

Ms 120B-173 
Plate 1. 1. Bathysiphon brosgei Tappan, Sample 120-748C-48R-1, 20-22 cm, CPC (Commonwealth Paleontological Collection, Bureau of Mineral Resources, Geology and Geophysics, Canberra) 28761, ×50. 2. Saccammina sp. 1, Sample 120-748C-61R-CC, CPC 28762, ×145. 3. Saccammina sp. indet., Sample 120-748C-61R-CC, CPC 28763, ×235. 4. Saccammina sp. indet., Sample 120-748C-62R-CC, CPC 28764, $\times 130$. 5. ?Saccammina sp., Sample 120-750B-11W-2, sweep, CPC 28765, $\times 80$. 6. Bolivinopsis rosula (Ehrenberg), Sample 120-747A-21X-2, 60-62 cm, CPC 28766, $\times 80.7$. Bolivinopsis spectabilis (Grzybowski), Sample 120-748C-28R-1, $99 \mathrm{~cm}, \mathrm{CPC}$ 28767 , $\times 30$. 8. Spiroplectammina grzybowskii Frizzell, Sample 120-747A-22X-3, 28-32 cm, CPC $28768, \times 65$. 9. Spiroplectammina laevis (Roemer), Sample $120-747 \mathrm{~A}-26 \mathrm{X}-4,28-32 \mathrm{~cm}, \mathrm{CPC}$ $28769, \times 50$. 10. Spiroplectammina sp., Sample 120-748C-47R-1, 124-126 cm, CPC 28770, $\times 100$. 11. Spiroplectammina paula Belford, Sample 120-747A-27X-1, 28-32 cm, CPC 28771, ×90. 12. Gaudryina rugosa d'Orbigny, Sample 120-747A-25X-CC, CPC 28772, $\times 35$. 13. Arenobulimina americana Cushman, Sample 120-747A-23X-5, 28-32 cm, CPC 28773, ×160. 14. Dorothia bulletta (Carsey), Sample 120-748C-49R-CC, CPC 28774, $\times 95$. 15. Dorothia confraga Belford, Sample 120-750A-15R-CC, CPC $28775, \times 120$. 16. Dorothia conicula Belford, Sample 120-747A$26 \mathrm{X}-2,28-32 \mathrm{~cm}$, CPC 28776, $\times 85$. 17. Marssonella oxycona (Reuss), Sample 120-747A-25X-CC, CPC 28777, $\times 75$. 18. Spirillina sp., Sample 120-748C-46R-2, 36-38 cm, CPC 28778, ×135. 19, 20. Patellina subcretacea Cushman and Alexander, Sample 120-750A-16R-3, 28-32 cm, CPC 28779; (19) $\times 125 ;(20) \times 160$. 21. Dentalina alternata (Jones), Sample $120-750 \mathrm{~B}-5 \mathrm{R}-1,16-18 \mathrm{~cm}, \mathrm{CPC}$ $28780, \times 35$. 22. Dentalina basiplanata Cushman, Sample 120-750A-18R-CC, CPC $28781, \times 50$. 23. Dentalina basitorta Cushman, Sample 120-747A-25X-CC, CPC 28782, $\times 45$. 24. Dentalina catenula Reuss, Sample 120-747A-22X-CC, CPC 28783 , $\times 35$. 25. Dentalina confluens Reuss, Sample 120-750A-18R-1, 51-55 cm, CPC $28784, \times 50$. 26. Dentalina gracilis d'Orbigny, Sample 120-750A-21R-CC, CPC 28785, $\times 40$. 27. Dentalina inornata d'Orbigny, Sample 120-747A-22XCC, CPC 28786, ×45. 28. Dentalina legumen Reuss, Sample 120-747A-27X-CC, CPC 28787, ×50. 29. Dentalina lorneiana d'Orbigny, Sample 120-748C-27R-1, 90-91 cm, CPC 28788, $\times 50.30$. Dentalina luma Belford, Sample 120-747A-22X-5, 28-32 cm, CPC 28789, ×50. 31. Dentalina marcki Reuss, Sample 120-747A-22X-CC, CPC 28790, $\times 60$. 32. Dentalina reflexa Morrow, Sample 120-747A-23X-7, 28-32 cm, CPC 28791, $\times 65$. 33. Dentalina sororia Reuss, Sample 120-747C-7R-1, 27-29 cm, CPC 28792, $\times 40$. 34. Dentalina sp. A (Belford), Sample 120-747A$25 X-5,28-32 \mathrm{~cm}$, CPC 28793, $\times 30$. 35. Dentalina sp. 1, Sample 120-747A-22X-3, 40-42 cm, CPC $28794, \times 60$. 36. Dentalina sp. 2 , Sample 120-750A-19R-CC, CPC $28795, \times 50.37$. Nodosaria affinis Reuss, Sample 120-747A-25X-CC, CPC 28796, $\times 25$. 38. Nodosaria aspera Reuss, Sample 120-747A-24X-1, 62-66 cm, CPC 28797, $\times 55$. 

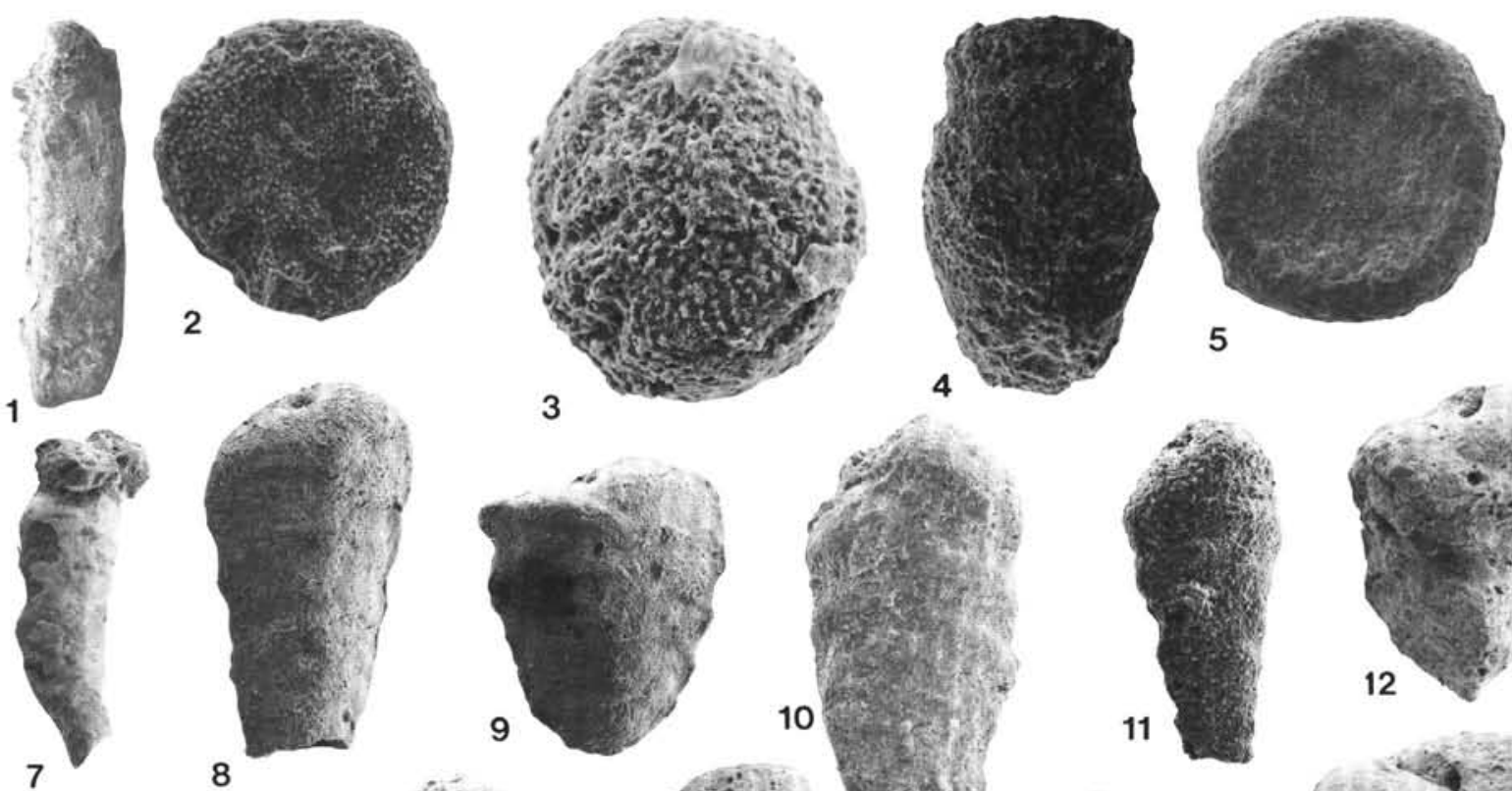

5

6
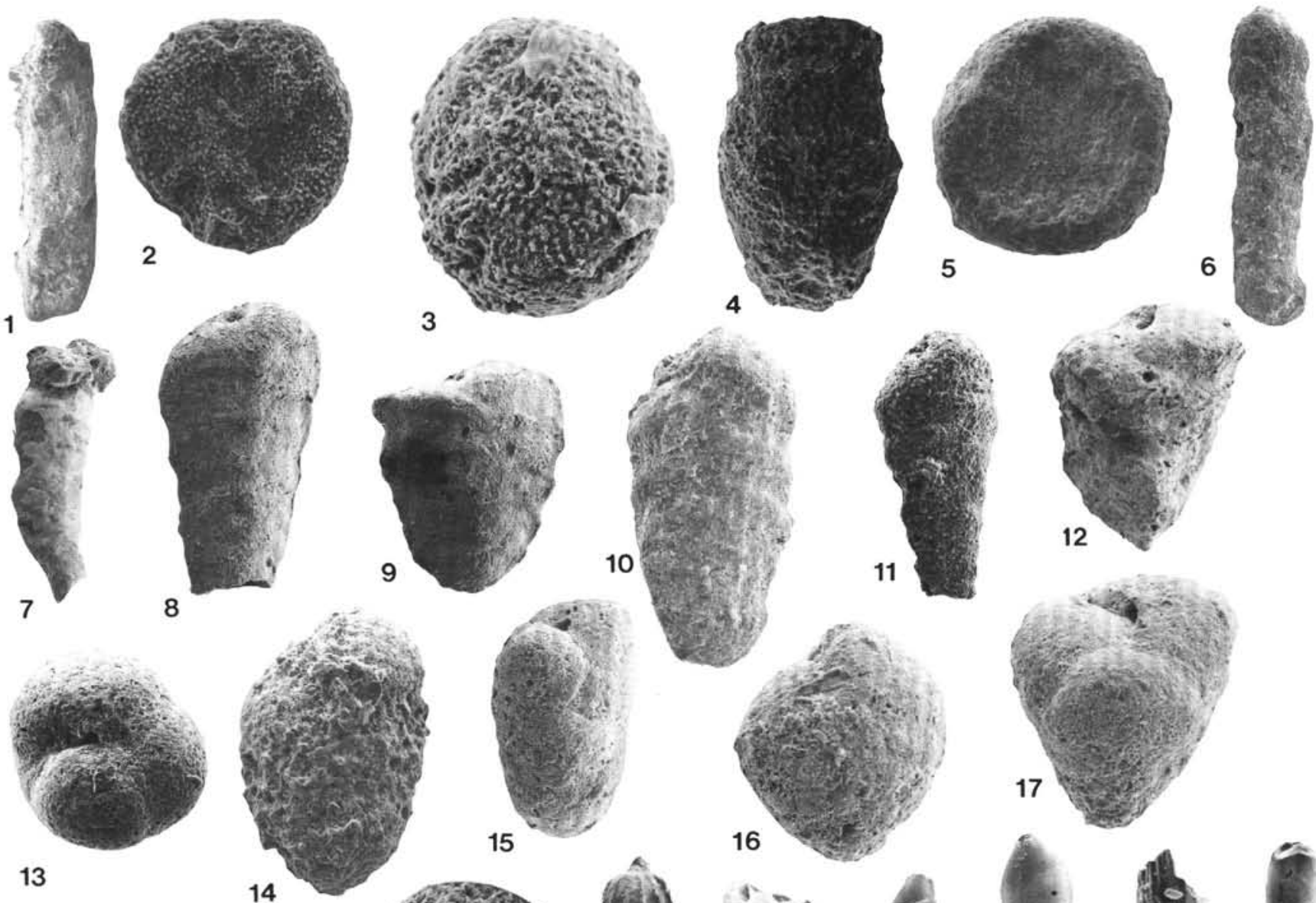

13
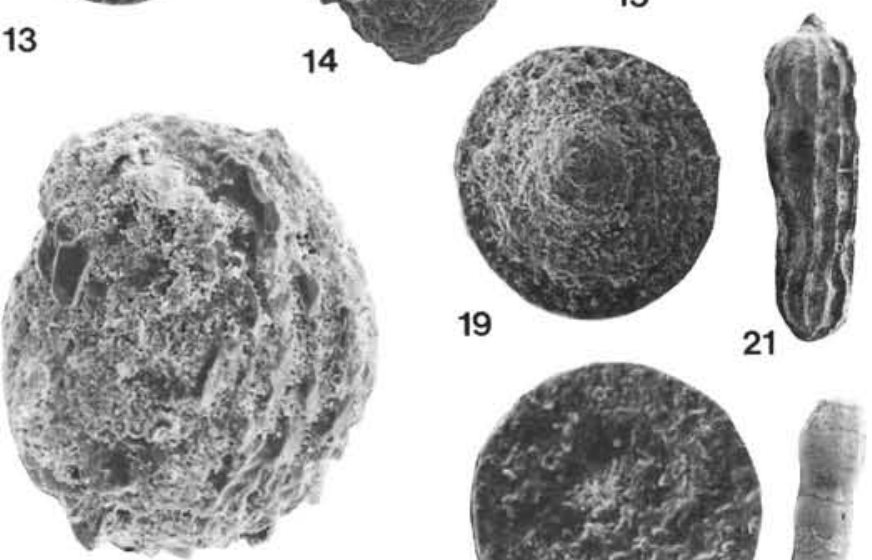

18
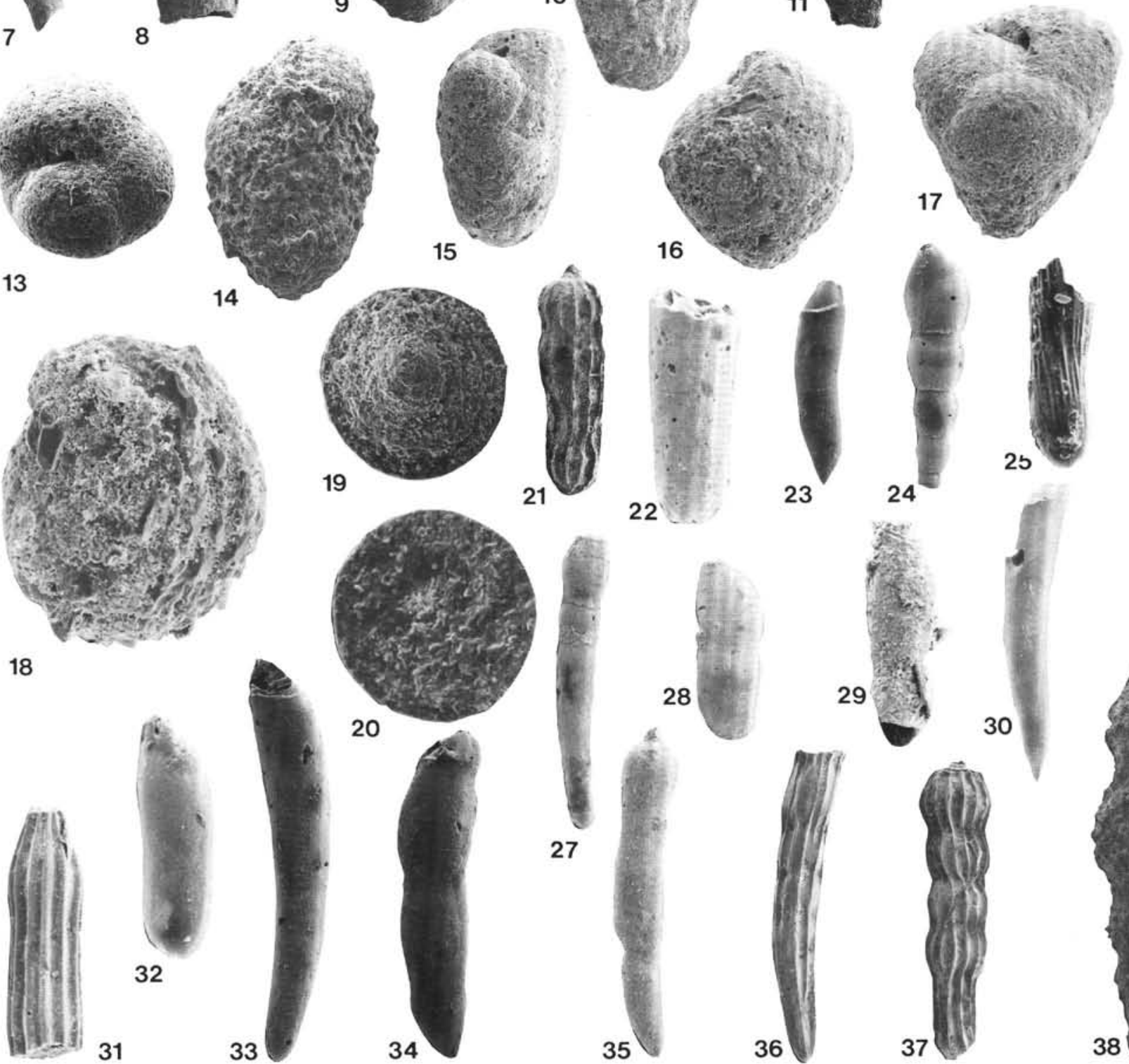

26

31

33

34

36

37

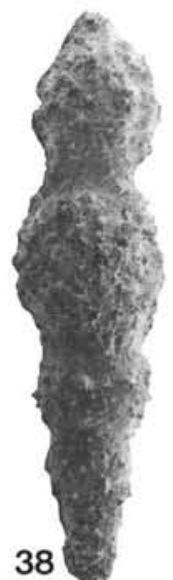


Plate 2. 1. Nodosaria limbata d'Orbigny, Sample 120-750A-17R-CC, CPC 28798, ×60. 2. Nodosaria prismatica Reuss, Sample 120-750B-4W-2, $25 \mathrm{~cm}$, CPC 28799, $\times 50$. 3. Nodosaria proboscidea Reuss, Sample 120-747A-21X-3, 40-42 cm, CPC 28800, $\times 100$. 4. Nodosaria septemcostata Geinitz, Sample 120-750B-3R-1, $18 \mathrm{~cm}$, CPC 28801, $\times 75.5$, 6. Nodosaria sp.; (5) Sample 120-750A-15R-CC, CPC 28802, ×105; (6) Sample 120-747A-23X-5, 28-32 cm, CPC 28803, $\times 80$. 7. Lingulina sp. 1, Core $120-750 \mathrm{~B}-6 \mathrm{~W}$, top of core, CPC $28804, \times 85.8$. Frondicularia archiaciana d'Orbigny, Sample 120-747A-25X-CC, CPC 28805, $\times 50.9$. Frondicularia intermittens Reuss, Sample 120-747A-25X-CC, CPC 28806, $\times 20$. 10. Frondicularia inversa Reuss, Sample 120-748C-55R-3, 138-140 cm, CPC 28807 , $\times 30$. 11. Frondicularia aff. lanceola Reuss, Sample $120-747$ C -8 R-1, $25-28 \mathrm{~cm}$, CPC $28808, \times 30$. 12. Frondicularia aff. lanceola Sample 120-750A-20R-CC, CPC 28809, $\times 30$. 13. Frondicularia striatula Reuss, Sample 120-748C-55R-4, $83-85 \mathrm{~cm}$, CPC $28810, \times 25$. 14. Tristix excavata (Reuss), Sample $120-748 \mathrm{C}-35 \mathrm{R}-1,73-75 \mathrm{~cm}$, CPC 28811, ×80. 15. Berthelinella sp., Sample 120-748C-40R-1, 22-24 cm, CPC 28812, ×130. 16. Lenticulina acutauricula (Fichtel and Moll), Sample 120-747A-22X-CC, CPC 28813, ×40. 17. Lenticulina discrepans (Reuss), Sample 120-747A-22X-5, 28-32 cm, CPC 28814, ×80. 18. Lenticulina macrodiscus (Reuss), Sample 120-747A-22X-2, 28-32 cm, CPC 28815, ×95. 19. Lenticulina navicula (d'Orbigny), Sample 120-747A-23X-CC, CPC 28816, $\times 55$. 20. Lenticulina sp. 1, Sample 120-747A-22X-2, 28-32 cm, CPC 28817, $\times 80$. 21. Lenticulina sp. 1 and 2, Sample 120-750A-15R-CC, CPC 28818, $\times 145$. 22. Marginulinopsis striatocarinata (Cushman and Campbell), Sample 120-748C-23R-1, 33-36 cm, CPC 28819, $\times 20$. 23. Marginulinopsis sp., Sample $120-750 \mathrm{~B}-8 \mathrm{~W}-2,10 \mathrm{~cm}, \mathrm{CPC} 28820, \times 30.24$. Neoflabellina rugosa (d'Orbigny), Sample 120 747 A-23X-4, 28-32 cm, CPC 28821, $\times 50.25$. Astacolus aff. richteri (Brotzen), Sample 120-747A27X-CC, CPC 28822, $\times 100$. 26. Marginulina austinana Cushman, Sample 120-748C-46R-CC, CPC 28823, ×75. 27. Marginulina bullata Reuss, Sample 120-750A-15R-CC, CPC 28824, ×90. 28. Marginulina curvatura Cushman, Sample 120-748C-51R-CC, CPC 28825, ×140. 29. Marginulina inconstantia Cushman, Sample 120-750B-8W-2, 4-6 cm, CPC 28826, $\times 65$. 30. Marginulina texasensis Cushman, Sample 120-747A-21X-2, 60-62 cm, CPC $28827, \times 120$. 31. Marginulina trilobata d'Orbigny, Sample 120-747A-23X-2, 28-32 cm, CPC 28828, $\times 40$. 32. Marginulina sp. 1, Sample 120-747A-26X-CC, CPC 28829, $\times 70$. 


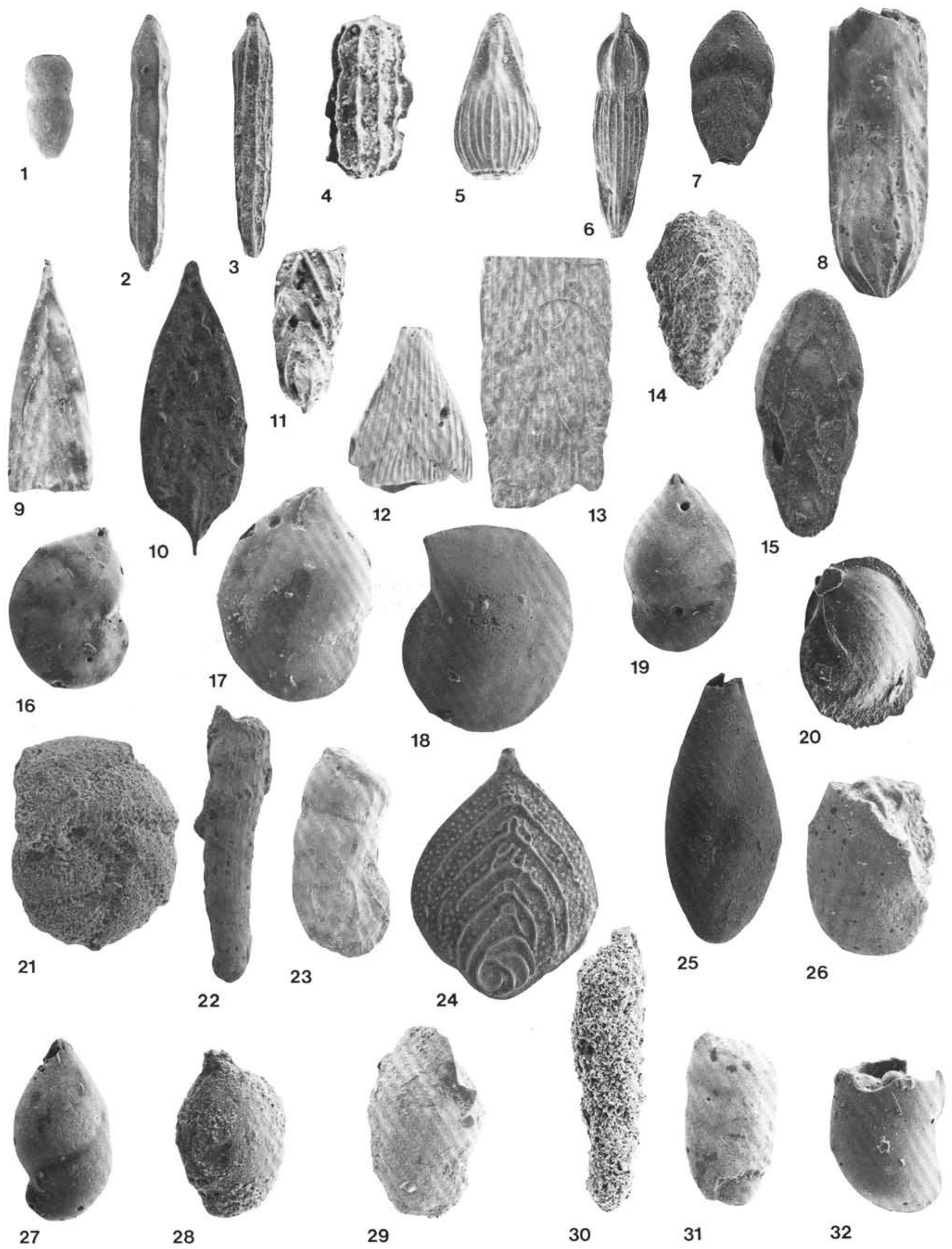


Plate 3. 1. Marginulina sp. 2, Sample $120-747$ A-26X-CC, CPC $28830, \times 75$. 2. Planularia dissona (Plummer), Sample 120-750B-7W-1, top, CPC 28831, $\times 60$. 3. Planularia tricarinella (Reuss), Sample 120-747A-25X-CC, CPC $28832, \times 55$. 4. Vaginulina paucistriata Reuss, Sample 120 750B-11W-2, sweep, CPC 28833, ×45. 5. Vaginulina aff. wadei Kelley, Sample 120-750B-11W-2, $128 \mathrm{~cm}$, dark, CPC 28834, $\times 75$. 6. Vaginulina sp., Sample 120-750A-17R-CC, CPC 28835, $\times 60$. 7. Ellipsocristellaria sp., Sample 120-750B-9W-2, 37-39 cm, CPC 28836, $\times 90$. 8. Lagena acuticosta Reuss, Sample 120-748C-47R-1, 124-126 cm, CPC 28837, $\times 175$. 9. Lagena exsculpta Brady, Sample 120-747A-2H-CC, CPC 28838 , $\times 125$. 10. Lagena grahami Sliter, Sample 120-750A-15R-CC, CPC 28839, $\times 185$. 11. Lagena aff.plumigera Brady, Sample 120-747A-22X-3, $28-32 \mathrm{~cm}$, CPC 28840, $\times 145$. 12. Lagena semiinterrupta Berry, Sample 120-747A-22X-CC, CPC $28841, \times 130$. 13. Lagena substriata Williamson, Sample $120-748 \mathrm{C}-47 \mathrm{R}-1,124-126 \mathrm{~cm}$, CPC $28842, \times 120.14$. Lagena sp. (Belford), Sample $120-747$ C-9R-1, 38-40 cm, CPC 28843, $\times 75.15$. Lagena sp. C, Sample 120-748C-30R-2, 38-40 cm, CPC 28844, $\times 230$. 16. Lagena sp. nov. (Barker, 1961), Sample 120-748C-28R-1, 76-79 cm, CPC 28845, ×70. 17. Lagena sp., Sample 120-747A-23X-3, 28-32 cm, CPC 28846, $\times 185$. 18. Globulina lacrima (Reuss), Sample 120-747A$24 X-4,70-74 \mathrm{~cm}$, CPC $28847, \times 130$. 19. Globulina prisca Reuss, Sample 120-747A-23X-CC, CPC 28848, $\times 65$. 20. Guttulina adhaerens (Olszewski), Sample 120-750A-21R-CC, CPC 28849, $\times 105$. 21. Guttulina cuspidata Cushman and Ozawa, Sample 120-748C-46R-CC, CPC 28850, $\times 120.22$. Guttulina subsphaerica Sample 120-747A-22X-CC, CPC 28851, $\times 55$. 23. Pyrulina apiculata (Marie) Sample 120-747A-21X-3, 40-42 cm, CPC 28852, $\times 125$. 24. Pyrulina cylindroides (Roemer), Sample 120-747A-27X-CC, CPC 28853, $\times 50$. 25. Ramulina sp., Sample 120-747A24X-1, 62-66 cm, CPC 28854, $\times 110$. 26. Oolina apiculata Reuss, Sample 120-747A-23X-CC, CPC 28855, $\times 135$. 27. Oolina delicata (Sliter), Sample 120-748C-33R-1, 33-36 cm, CPC 28856, $\times 130$. 28. Oolina globosa (Montagu), Sample 120-747A-23X-CC, CPC 28857, $\times 90$. 29. Oolina sp., Sample 120-750A-18R-CC, CPC 28858, $\times 45$. 30. Fissurina sp., Sample 120-748C-29R-CC, CPC 28859, $\times 105$. 31. Dainita sp., Sample 120-747A-24X-CC, CPC $28860, \times 50$. 32. Glandulina manifesta Reuss, Sample 120-750A-20R-CC, CPC 28861, $\times 90.33$. Polymorphinid gen. et sp. indet., Sample 120-747A-24X-5, 37-39 cm, CPC 28862, ×95. 34, 35. Ceratobulimina cretacea Cushman and Harris, Sample 120-750A-17R-3, 28-32 cm, CPC 28863; (34) dorsal, $\times 185$; (35) ventral, $\times 145$. 


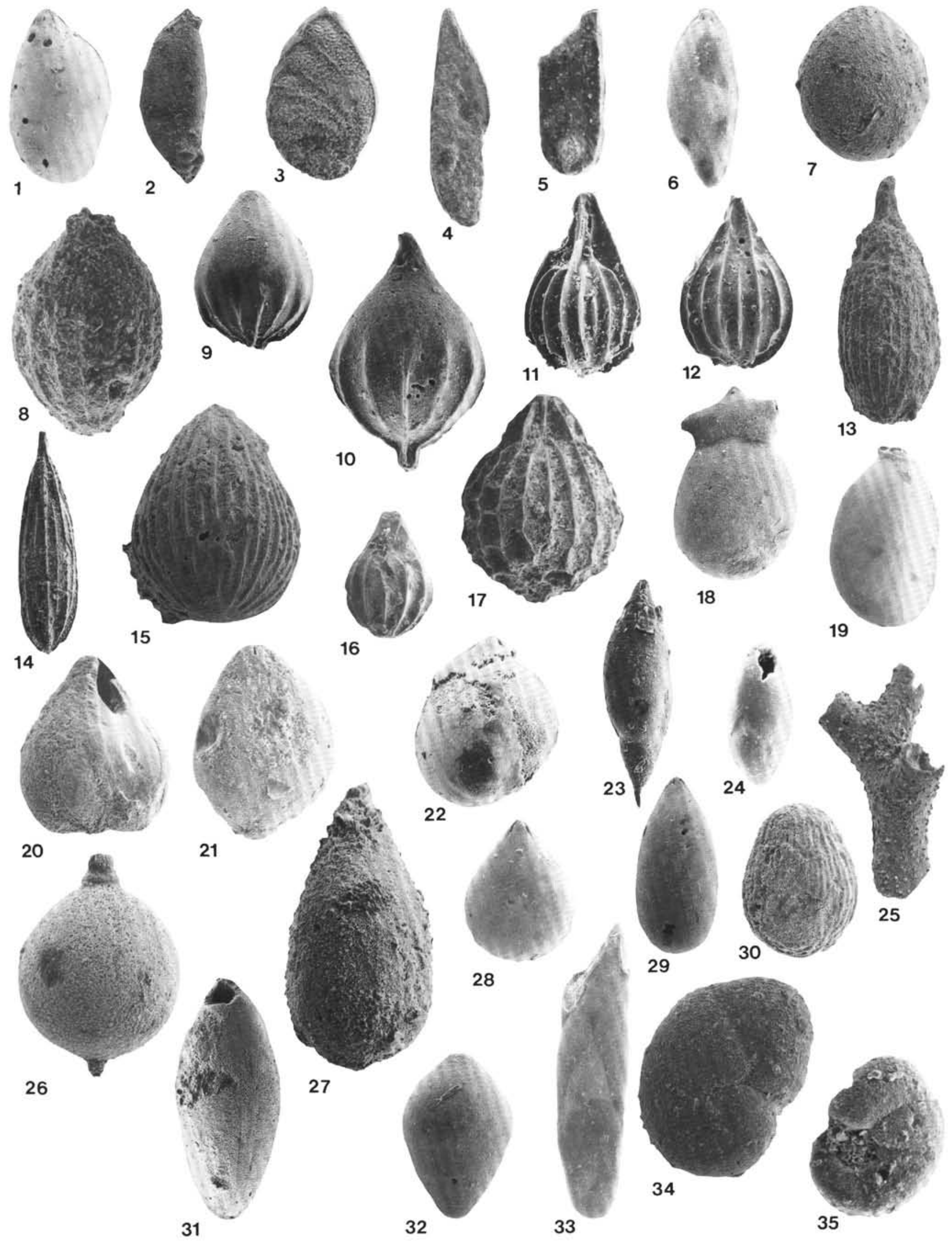


Plate 4. 1, 2. Conorboides sp., Sample 120-747A-26X-CC, CPC 28864, $\times 125$; (1) dorsal; (2) ventral. 3. Bolivina aff. pondi Cushman, Sample 120-750A-15R-CC, CPC 28865, ×220. 4. Bolivinoides draco draco (Marsson), Sample 120-750A-15R-CC, CPC 28866, $\times 85$. 5. Bolivinoides granulatus, Sample 120-747A-23X-7, 28-32 cm, CPC 28867, $\times 85$. 6. Bolivinoides granulatus (Brotzen), Sample 120-750A-21R-CC, CPC $28868, \times 85$. 7. Bolivinoides sirticus Barr, Sample 120-747A-23X-CC, CPC 28869, $\times 110.8$. Bolivinoides strigillatus (Chapman), Sample 120-747A$27 \mathrm{X}-\mathrm{CC}$, CPC $28870, \times 85$. 9. Bolivinoides laevigatus, Sample 120-748C-27R-1, $90-91 \mathrm{~cm}, \mathrm{CPC}$ 28871, $\times 130$. 10. Aragonia sp. 1, Sample 120-747A-23X-4, 28-32 cm, CPC 28872, ×140. 11. Aragonia sp. 2, Sample 120-750B-8W-2, 4-6 cm, CPC 28873, $\times 180$. 12. Loxostomum eleyi (Cushman), Sample 120-747A-27X-CC, CPC 28874, $\times 85$. 13. Loxostomum sp. 1, Sample 120-747A-24X-CC, CPC 28875 , $\times 55$. 14. Loxostomum sp. 2, Sample 120-747A-27X,CC, CPC $28876, \times 80$. 15. Eouvigerina sculptura $\mathrm{McNeil}$ and Caldwell, Sample $120-747 \mathrm{~A}-26 \mathrm{X}-2,28-32 \mathrm{~cm}$, CPC 28877, $\times 100$. 16. Eouvigerina hispida Cushman, Sample 120-747A-25X-1, 28-32 cm, CPC $28878, \times 115$. 17. Praebulimina aspera Cushman and Parker, Sample 120-750A-17R-1, 28-32 cm, CPC 28879, $\times 150$. 18. Praebulimina callahani (Galloway and Morrey), Sample 120-747A-23X-1, 28-32 cm, CPC 28880, $\times 120$. 19. Praebulimina carseyae (Plummer), Sample 120-750B-8W-2, 4-6 cm, CPC 28881, $\times 125$. 20. Praebulimina plana Cushman and Parker, Sample 120-747A24X-1, 62-66 cm, CPC 28882, $\times 140$. 21. Praebulimina aff. prolixa (Cushman and Parker), Sample 120-747A-22X-CC, CPC 28883, $\times 75$. 22. Praebulimina reussi (Morrow), Sample 120-747A$22 \mathrm{X}-6,28-32 \mathrm{~cm}$, CPC $28884, \times 120$. 23. Praebulimina sp. 1, Sample 120-747A-23X-CC, CPC 28885, $\times 140$. 24. Praebulimina sp. 2, Sample 120-747A-23X-4, 28-32 cm, CPC 28886, $\times 125.25$, 26. Praebulimina sp. 3, Sample 120-748C-28R-1, 76-79 cm, CPC $28887, \times 185$; (25) oblique apertural; (26) oblique view, aperture to right. 27. Pseudouvigerina cf. californica Sliter, Sample 120-748C-27R-1, 90-91 cm, CPC 28888, ×70. 28. Pyramidina rudita (Cushman and Parker), Sample 120-747A-25X-1, 28-32 cm, CPC $28889, \times 85$. 29. Pyramidina szajnochae (Grzybowski), Sample 120-747A-26X-CC, CPC $28890, \times 85$. 30. Pyramidina triangularis (Cushman and Parker), Sample 120-747A-22X-2, 28-32 cm, CPC 28891, $\times 60$. 31. Pyramidina sp. 1, Sample 120-750A16R-CC, CPC 28892, $\times 185$. 32. Pyramidina sp. 2, Sample 120-750A-16R-CC, CPC 28893, $\times 160$. 
UPPER CRETACEOUS BENTHIC FORAMINIFERS

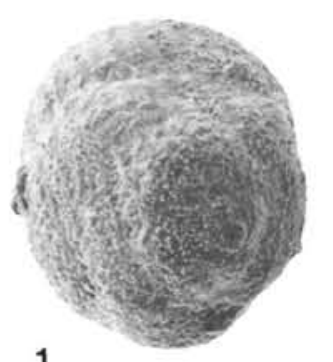

1
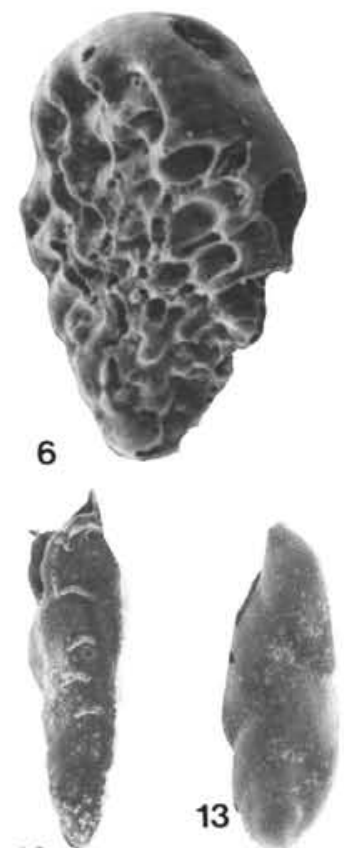

12

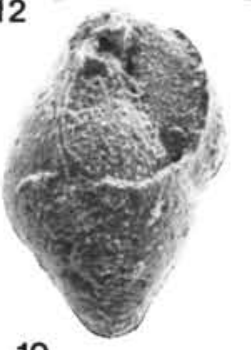

19

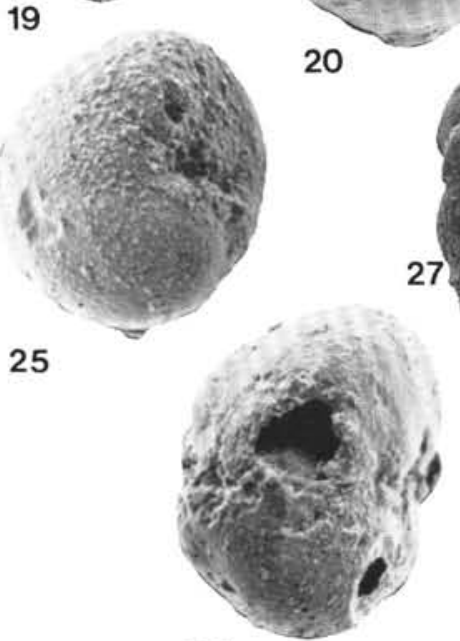

26

2
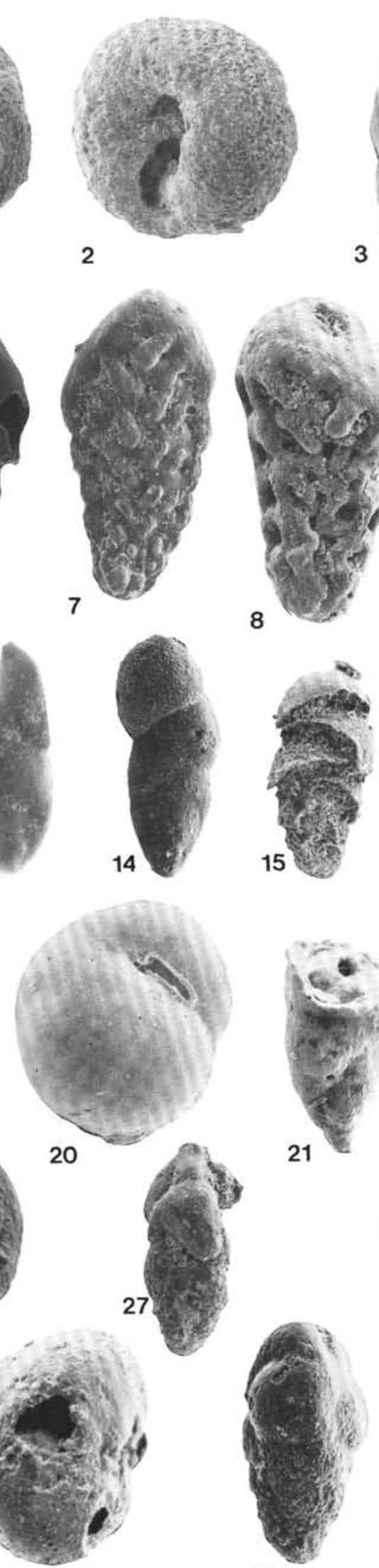

28

8

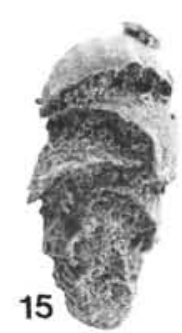

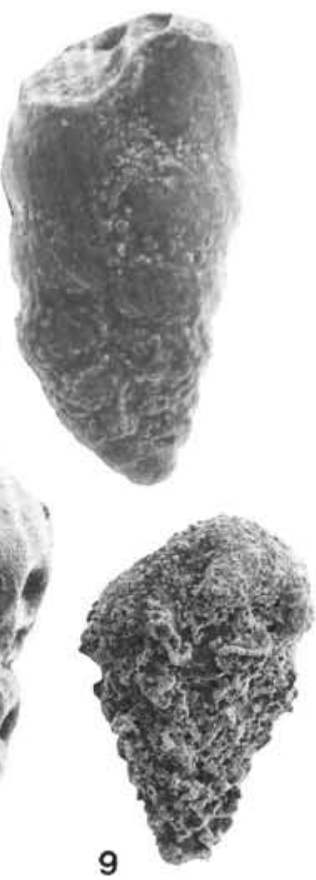
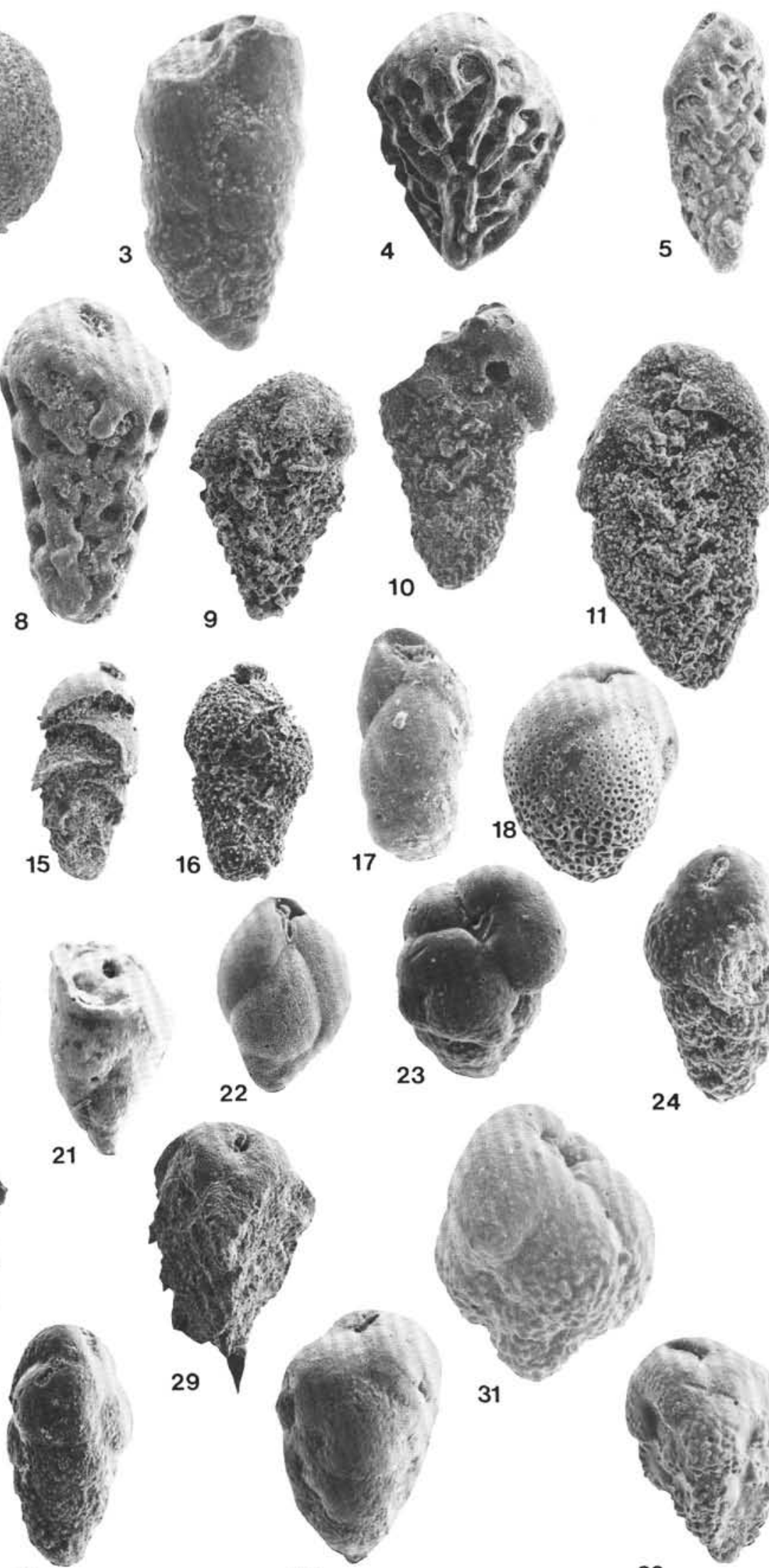

30
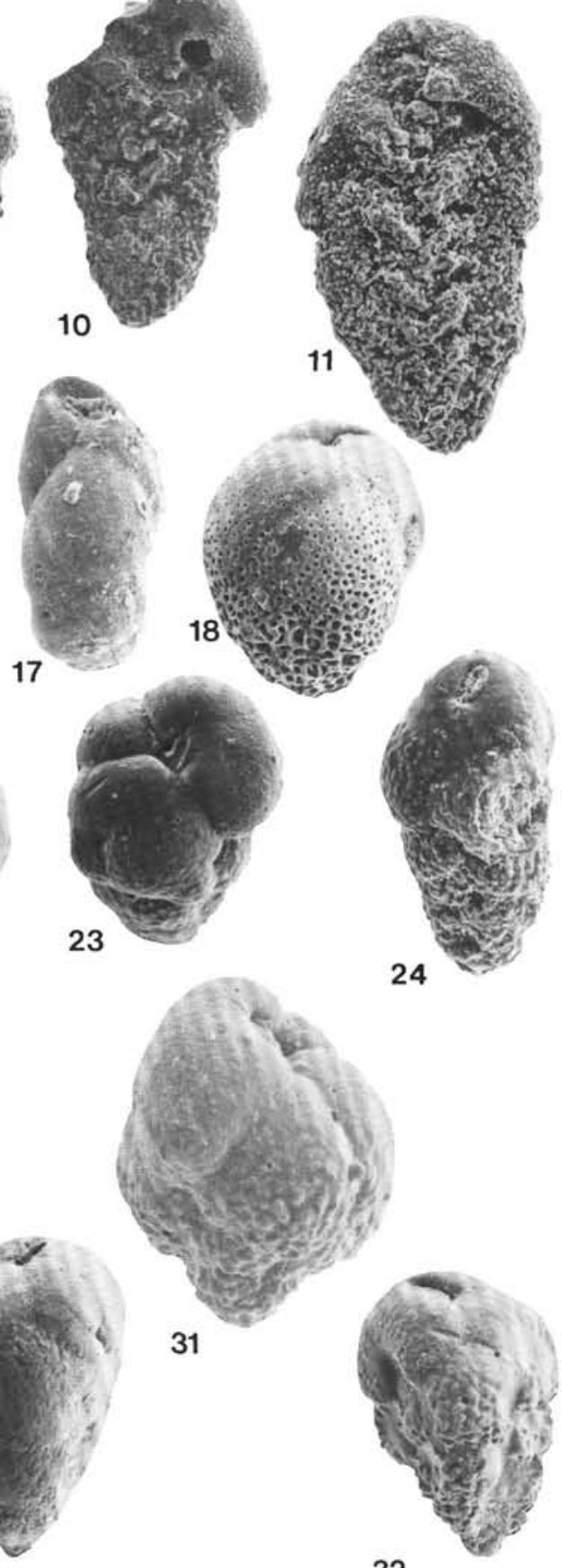

32 
Plate 5. 1. Pyramidina sp. 3, Sample 120-747A-25X-CC, CPC 28894, $\times 65.2$. Rectobolivina sp., Sample 120-748C-50R-CC, CPC 28895, $\times 115$. 3. Coryphostoma midwayensis (Cushman), Sample 120-747A-21X-2, 60-62 cm, CPC 28896, $\times 105$. 4. Ellipsoglandulina velascoensis Cushman, Sample 120-750B-8W-2, 4-6 cm, CPC 28897, ×90. 5, 6. Ellipsoidella gracillima (Cushman); (5) Sample 120-747A-23X-3, 28-32 cm, CPC 28898, ×80; (6) Sample 120-747A-26X-CC, CPC 28899, $\times 80$. 7. Ellipsoidella solida (Brotzen) Sample $120-750$ A-19R-CC, CPC $28900, \times 30$. 8. Ellipsoidella pleurostomelloides Heron-Allen and Earland, Sample 120-750A-22R-CC, CPC 28901, $\times 110$. 9, 10. Ellipsopolymorphina sp., Sample 120-747A-24X-CC, CPC 28902, (9) lateral, $\times 115$; (10) apertural, $\times 105$. 11. Pleurostomella binaria Belford, Sample 120-750A-17R-CC, CPC 28903, $\times 30$. 12. Pleurostomella subnodosa Reuss, Sample $120-747$ A-22X-2, 28-32 cm, CPC 28904, $\times 85$. 13. Pleurostomella zuberi Grzybowski, Sample 120-750A-22R-CC, CPC 28905, ×190. 14. Stilostomella alexanderi (Cushman), Sample 120-750A-16R-CC, CPC 28972, $\times 85$. 15. Stilostomella pseudoscripta (Cushman), Sample 120-747A-22X-CC, CPC 28906, $\times 65$. 16. Stilostomella stephensoni (Cushman), Sample 120-750A-17R-2, 25-29 cm, CPC 28907, $\times 90.17,18$. Valvulineria lenticula (Reuss), Sample 120-747A-22X-2, 28-32 cm, CPC 28908, $\times 130$; (17) dorsal; (18) ventral. 19. Valvulineria sp., Sample 120-747A-23X-CC, CPC 28909, ventral, $\times 130.20$. Cibicides beaumontianus, (d'Orbigny), Sample 120-748C-48R-CC, CPC 28910, ventral, $\times 115$. 21-23. Cibicides ribbingi Brotzen; (21) Sample 120-747A-27X-4, 28-32 cm, CPC 28911, normal form, ventral, $\times 60 ;(22,23)$ Sample $120-747$ C-10R-CC, CPC 28912, dorsal and ventral views of extreme form; (22) $\times 80$; (23) $\times 95$. 24, 25. Cibicides sp., Sample 120-747A-23X-CC, CPC 28913; (24) ventral, $\times 60 ;(25)$ dorsal, $\times 100.26,27$. Nuttallinella florealis (White), Sample 120-747A-26X-4, 28-32 cm, CPC 28914; (26) ventral, $\times 45$; (27) ventral, $\times 50.28,29$. Nuttallinella coronula (Belford), Sample 120-747A-26X-1, 28-32 cm, CPC 28915, $\times 65$; (28) dorsal; (29) ventral. 30. Pullenia americana Cushman, Sample 120-747A-23X-7, 28-32 cm, CPC 28916, ×140. 31. Pullenia cretacea Cushman, Sample 120-747A-21X-2, 60-62 cm, CPC 28916, $\times 130$. 32. Quadrimorphina halli Jennings, Sample 120-750A-19R-3, 28-32 cm, CPC 28918, $\times 110$. 33. Globimorphina sp., Sample 120-750A-16R-CC, CPC 28919, ×175. 34. Quadrimorphina allomorphinoides (Reuss), Sample 120-747C-7R-1, 27-29 cm, CPC 28920, $\times 115$. 
UPPER CRETACEOUS BENTHIC FORAMINIFERS

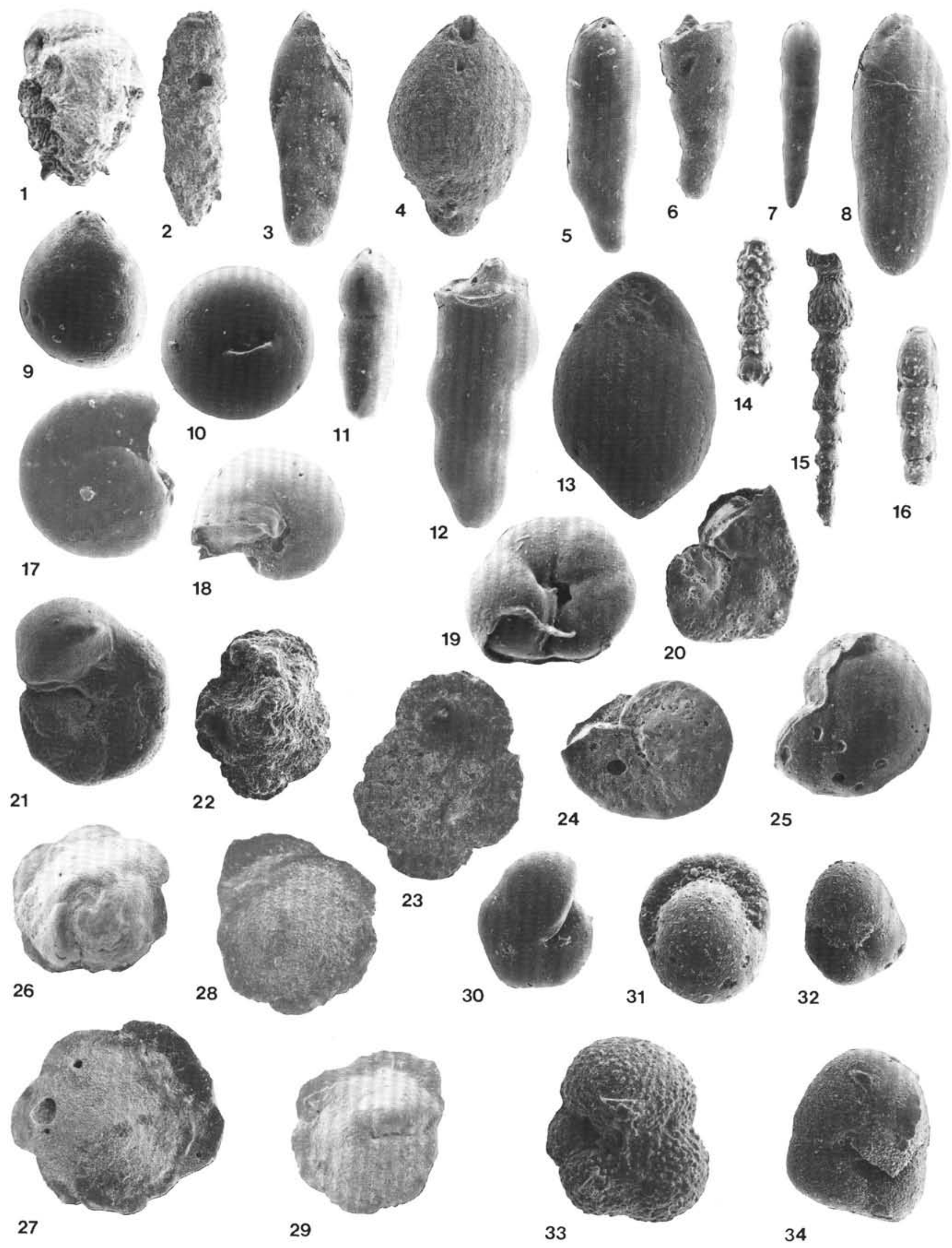


Plate 6. 1. Quadrimorphina camerata (Brotzen), Sample 120-748C-33R-1, 33-36 cm, CPC 28921 , $\times 155$. 2. Quadrimorphina sp., Sample $120-747 \mathrm{~A}-22 \mathrm{X}-2,28-32 \mathrm{~cm}$, CPC $28922, \times 120.3,4$. Alabamina dorsoplana (Brotzen), Sample 120-747C-10R-CC, CPC 28923; (3) ventral, $\times 125$; (4) dorsal, $\times 135$. 5, 6. Globorotalites spineus (Cushman), Sample 120-750B-11W-2, sweep, CPC 28924; (5) ventral, $\times 165$; (6) dorsal, $\times 165$. 7, 8. Globorotalites umbilicatus (Loetterle), Sample 120-747A-21X-3, 40-42 cm, CPC 28925; (7) ventral, $\times 140$; (8) dorsal, $\times 140.9,10$. Charltonina ripleyensis (Sandidge), Sample 120-750A-15R-CC, CPC 28926; (9) oblique ventral, $\times 140$; (10) dorsal, $\times 140.11,12$. Osangularia cordieriana (d'Orbigny), Sample 120-747A-23X-6, 28-32 cm, CPC 28927; (11) ventral, $\times 120$; (12) dorsal, $\times 95.13,14$. Osangularia aff. cordieriana (d'Orbigny), Sample 120-747A-21X-2, 60-62 cm, CPC 28928; (13) ventral, $\times 165$; (14) dorsal, $\times 120.15$, 16. Osangularia texana (Cushman), Sample 120-747C-9R-1, 38-40 cm, CPC 28929; (15) dorsal, $\times 105 ;(16)$ ventral, $\times 90.17,18$. Osangularia velascoensis (Cushman), Sample 120-747A-22X-CC, CPC 28930; (17) ventral, $\times 70$; (18) dorsal, $\times 85.19$, 20. Osangularia sp., Sample 120-747A-22XCC, CPC 28931; (19) ventral, $\times 60$; (20) dorsal, $\times 85$. 21. Anomalinoides sp., Sample 120-747A23X-7, 28-32 cm, CPC 28932, $\times 80$. 22-24. Alabamina australis Belford, Sample 120-748C54R-2, 41-43 cm, CPC 28933, ×130; (22) ventral; (23) apertural, and (24) dorsal, 25, 26. Heterolepa carlsbadensis Sliter, Sample 120-748C-54R-2, 41-43 cm, CPC 28934; (25) ventral, $\times 130$; (26) dorsal, $\times 115.27,28$. Gyroidinoides bandyi (Trujillo), Sample 120-750B-11W-2, $75 \mathrm{~cm}$, CPC 28935, $\times 105$; (27) apertural; (28) dorsal. 29, 30. Gyroidinoides concinna (Brotzen), Sample 120-750A-17R-1, 28-32 cm, CPC 28936; (29) ventral, $\times 155$; (30) dorsal, $\times 200.31,32$. Gyroidinoides diversus (Belford), Sample 120-747A-21X-3, 40-42 cm, CPC 28937; (31) ventral, $\times 65$; (32) dorsal, $\times 100$. 


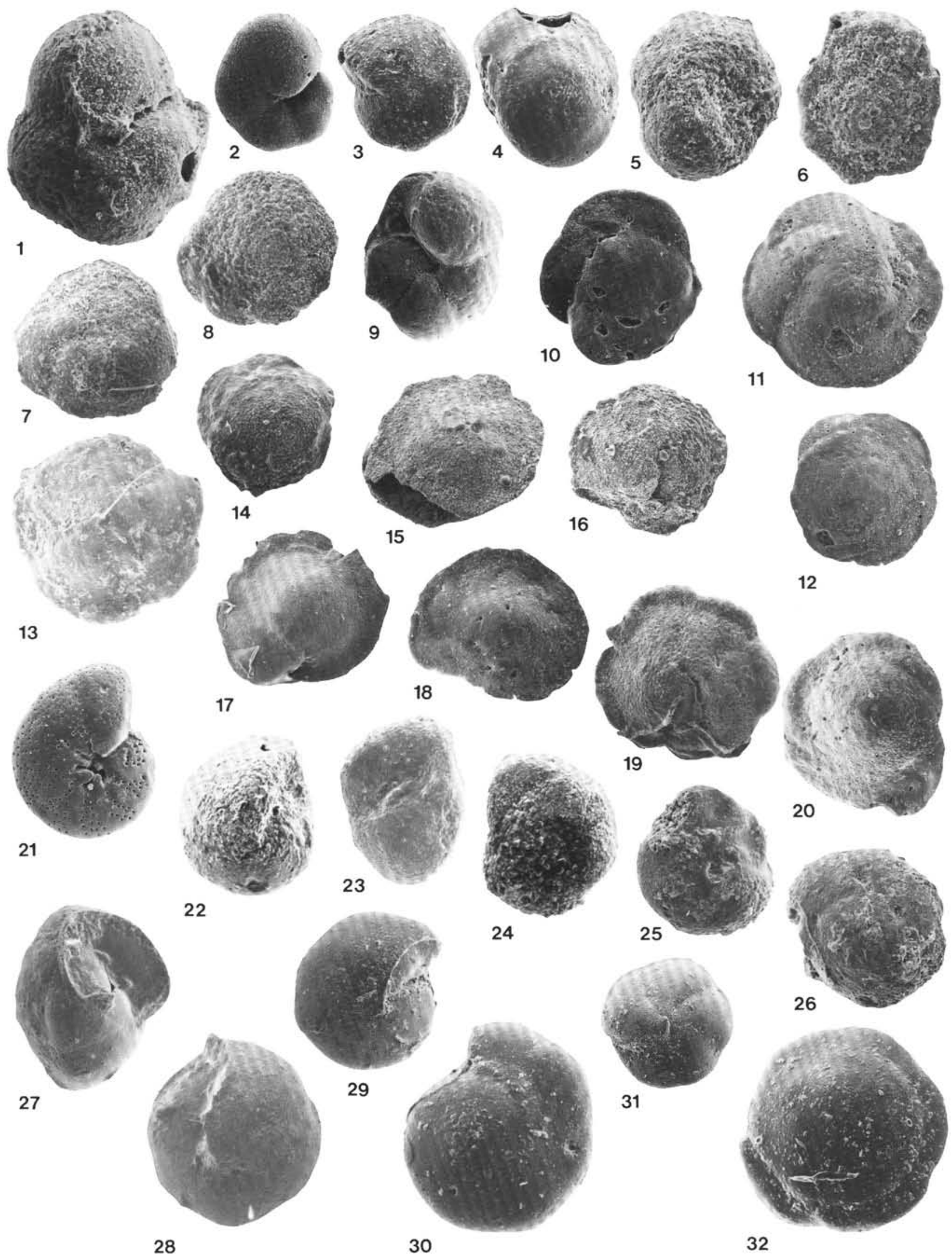


Plate 7. 1-3. Gyroidinoides exsertus (Belford), Sample 120-750B-9W-2, 37-39 cm, CPC 28938; (1) dorsal, $\times 50$; (2) ventral, $\times 70$; (3) lateral, $\times 65.4,5$. Gyroidinoides globosa (Hagenow), Sample 120-747A-22X-CC, CPC 28938; (4) apertural, $\times 95$; (5) ventral, $\times 65.6,7$. Gyroidinoides goudkoffi (Trujillo), Sample 120-750A-16R-CC, CPC 28940; (6) lateral, $\times 210$; (7) dorsal, $\times 200.8$, 9. Gyroidinoides aff. haidingeri (d'Orbigny), Sample 120-750B-9W-1, 1-8 cm, CPC 28941; (8) ventral, $\times 140$; (9) dorsal, $\times 150$. 10, 11. Gyroidinoides nitidus (Reuss), Sample 120-747A-22X-2, $28-32 \mathrm{~cm}$, CPC 28942; (10) oblique dorsal, $\times 80$; (11) ventral, $\times 85.12,13$. Gyroidinoides nitidus (Belford), Sample 120-747A-22X-5, 28-32 cm, CPC 28943; (12) ventral, $\times 120$; (13) dorsal, $\times 115$. 14, 15. Gyroidinoides aff. nonionoides (Bandy), Sample 120-750B-9W-1, 1-8 cm, CPC 28944; (14) dorsal, $\times 95$; (15) ventral, $\times 85.16,17$. Gyroidinoides quadratus (Cushman and Church), Sample 120-747A-22X-CC, CPC 28945; (16) ventral, $\times 105$; (17) dorsal, $\times 140.18,19$. Gyroidinoides $\mathrm{sp} .1$, Sample 120-750A-16R-4, 28-32 cm, CPC 28946; (18) ventral, $\times 185$; (19) dorsal $\times 185.20,21$. Gyroidinoides sp., Sample 120-750A-16R-3, 28-32 cm, CPC 28947; (20) ventral, $\times 170$; (21) dorsal, $\times 210$. 22, 23. Notoplanulina rakauroana (Finlay), Sample 120-747A-25X-CC, CPC 28948; (22) dorsal, $\times 45$; (23) ventral, $\times 45.24,25$. Notoplanulina compressa (Sliter), Sample 120-750B$11 \mathrm{~W}-2,75 \mathrm{~cm}$, CPC 28949; (24) ventral, $\times 105$; (25) dorsal, $\times 55.26,27$. Notoplanulina $\mathrm{n}$. sp., Sample 120-748C-28R-1, 76-79 cm, CPC 28950; (26) dorsal, $\times 75$; (27) ventral, $\times 65.28,29$. Stensioeina beccariiformis White, Sample 120-747A-21X-2, 60-62 cm, CPC 28951; (28) ventral, $\times 105$; (29) dorsal, $\times 95$. 

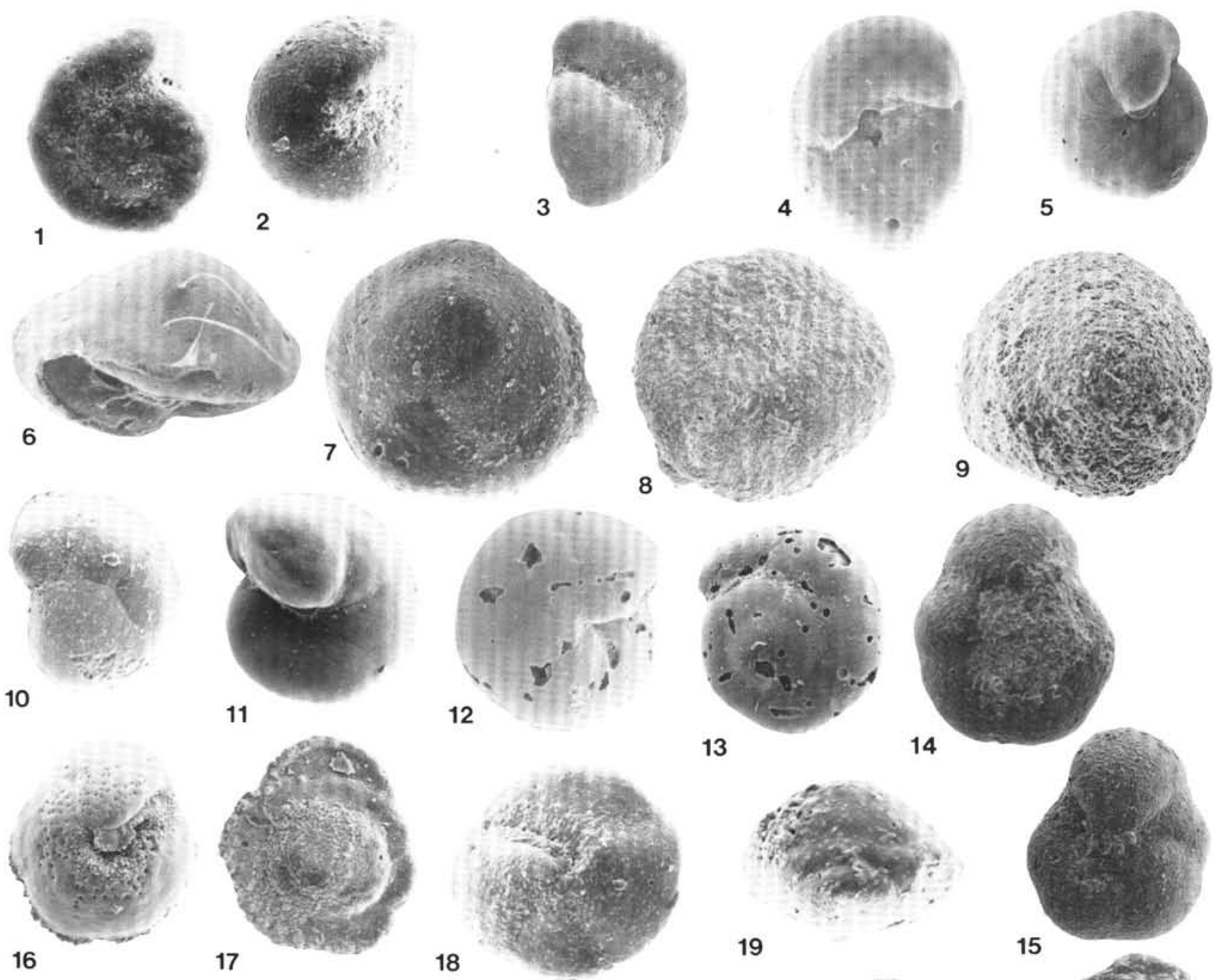

16

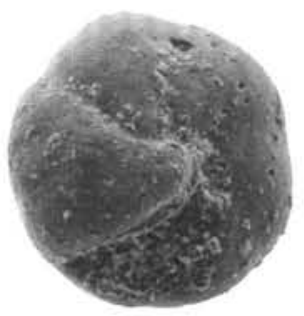

20

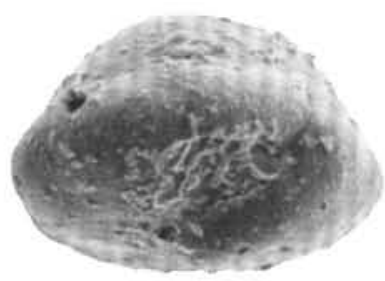

21

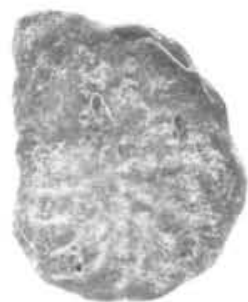

25
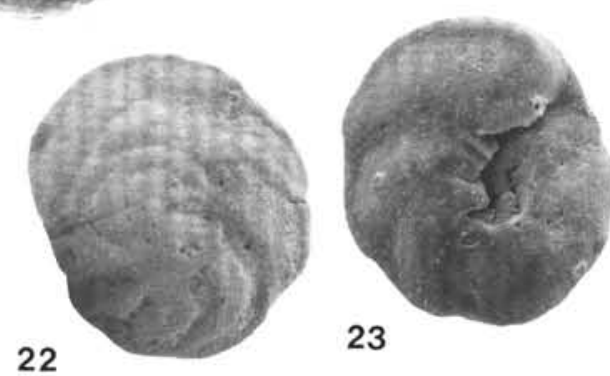

23

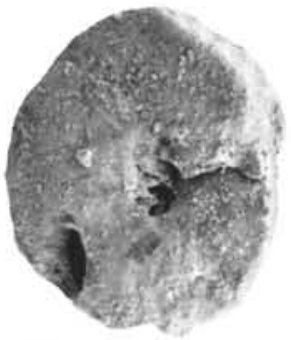

27

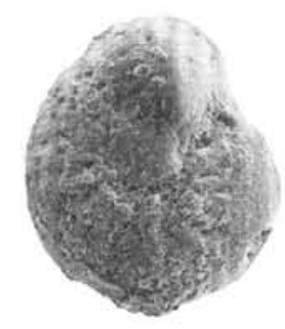

28

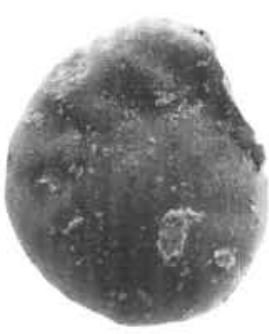

29 
Plate 8. 1, 2. Stensioeina sp. 1, Sample 120-750B-11W-2, $75 \mathrm{~cm}$, CPC 28952; (1) ventral, $\times 205$; (2) dorsal, $\times 190.3$. Gavelinella eriksdalensis (Brotzen), Sample 120-747A-22X-5, 28-32 cm, CPC 28953, $\times 90$, ventral. 4, 5. Gavelinella excavatus (Brotzen), Sample 120-747A-26X-CC, CPC 28954 , both ventral; $(4) \times 50$; $(5) \times 50.6,7$. Gavelinella harperi (Sandidge), Sample 120-748C28R-1, 76-79 cm, CPC 28955; (6) dorsal, $\times 85$; (7) ventral, $\times 85.8$. Gavelinella insculpta Belford, Sample 120-747A-26X-2, 28-32 cm, CPC 28956, $\times 120.9,10$. Gavelinella nacatochensis (Cushman), Sample 120-748C-36R-1, 81-83 cm, CPC 28957; (9) ventral, $\times 125$; (10) dorsal, $\times 125$. 11, 12. Gavelinella sandidgei (Brotzen); (11) Sample 120-750B-11W-2, $75 \mathrm{~cm}$, CPC 28958, $\times 105$; (12) Sample 120-747A-22X-6, 28-32 cm, CPC 28959, $\times 150$. 13. Gavelinella sandidgei (Brotzen) form B, Sample 120-748C-30R-2, 38-40 cm, CPC 28960, dorsal, $\times 105.14$. Gavelinella stellula (Belford), Sample 120-747A-22X-2, 28-32 cm, CPC 28961, ventral, $\times 95$. 15, 16. Gavelinella stephensoni (Cushman), Sample 120-747A-23X-CC, CPC 28962; (15) ventral, $\times 45$; (16) dorsal, $\times 50$. 17-19. Gavelinella trujillo Sliter, Sample 120-750B-9W-2, $37-39 \mathrm{~cm}$, CPC 28963 ; (17) ventral, $\times 55$; (18) lateral, $\times 60 ;(19)$ dorsal, $\times 50.20$. Gavelinella velascoensis (Cushman), Sample 120-747A-22X-CC, CPC 28964, ventral, $\times 35$. 21. Gavelinella aff. velascoensis (Cushman), Sample 120-747A-22X-2, 28-32 cm, CPC 28965, ventral, $\times 115.22,23$. Gavelinella sp., Sample 120-750A-16R-3, 28-32 cm, CPC 28966; (22) ventral, $\times 60$; (23) profile, $\times 55.24,25$. Gavelinella sp. 2, Sample 120-750A-24R-CC, CPC 28967; (24) ventral, $\times 130$; (25) dorsal, $\times 140.26,27$. Pararotalia praenaheolensis (Olsson), Sample 120-748C-46R-2, 36-38 cm, CPC 28968; (26) ventral, $\times 120$; (27) dorsal, $\times 160$. 28. "Anomalina" nelsoni W. Berry, Sample 120-748C-47R-1, $124-126 \mathrm{~cm}$, CPC $28969, \times 160.29,30$. gen. et sp. indet., Sample $120-750 \mathrm{~B}-10 \mathrm{~W}-1,60 \mathrm{~cm}, \mathrm{CPC}$ 28970, dorsal and ventral views, $\times 85.31$. Sessile form indet., Sample 120-748C-28R-1, $99 \mathrm{~cm}$, CPC $28971, \times 45$. 
UPPER CRETACEOUS BENTHIC FORAMINIFERS

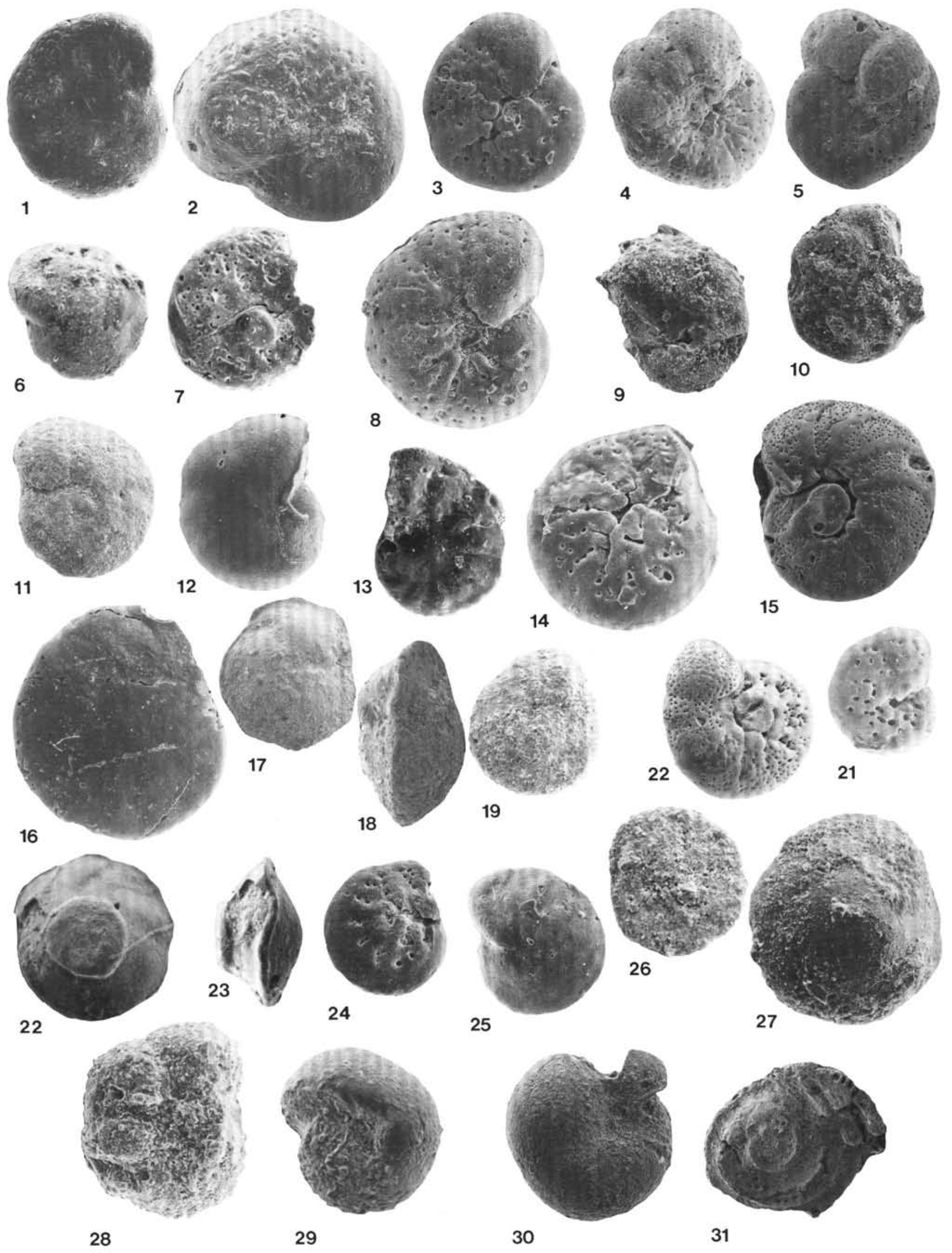

